\title{
An Inquiry into the Legal Standing of Rogue REMICs in Foreclosures
}

\author{
JAMES P. CAMPBELL \\ Capstone Advisor: Prof. Camille Walsh \\ Second Reader: Prof Keith Nitta
}

June 2016

A Capstone project presented in partial fulfillment

Of the requirements for the degree of

Master of Arts in Policy Studies

Interdisciplinary Arts and Sciences

University of Washington, Bothell, WA 


\begin{abstract}
The business of privatized mortgage loan securitization (Real Estate Mortgage Investment Conduits or "REMICS") is so arcane and specialized that few people outside of that realm of investment knowledge understand, or even care to understand how loan securitization functions. However, if the difference between a legitimate REMIC and a Rogue REMIC is adequately explained, one can begin to understand why Rogue REMICs must be exposed as unlawful enterprises whose affiliates are not only able to disregard existing federal securities and tax laws, but are also able to circumvent state and local foreclosure laws at will. These ongoing violations result from the intentional and commonplace shortcutting of the proper mortgage loan securitization processes during the several years preceding the 2008 financial crisis. This Inquiry will not focus primarily on how and why Rogue REMICS violate federal tax and securities laws; although those aspects are part of the discussion by necessity. I will argue that all Rogues lack the perquisite legal standing to prosecute both judicial and non-judicial foreclosures. I will present compelling evidence that, in the aftermath of the 2008 financial crisis, foreclosures by Rogues may have exceeded $10 \%$ of all foreclosures. I will further argue that county officials may be violating state laws by recording the documents that impart false legal standing to the Rogues. I will conclude with a suggestion to homeowners on how to proceed if a mortgage assignment to a Rogue turns up in the local County public records.
\end{abstract}




\section{CONTENTS}

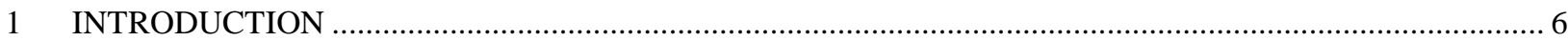

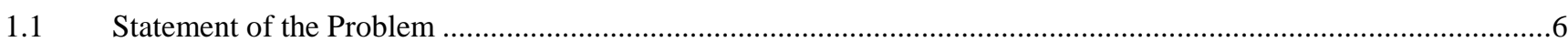

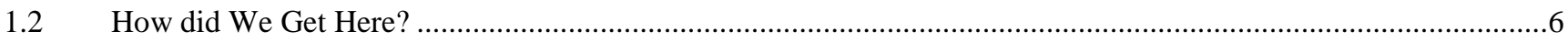

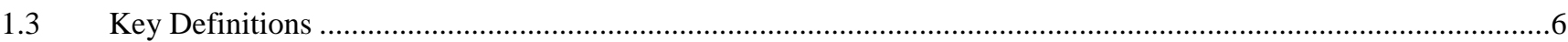

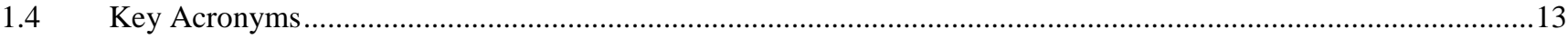

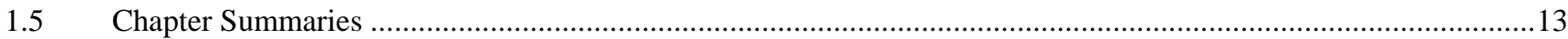

2 BACKGROUND OF MORTGAGE LOAN SECURITIZATION ……........................................................... 15

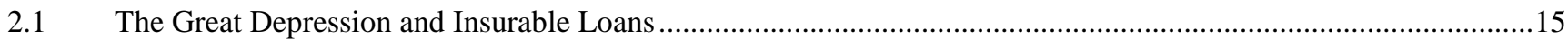

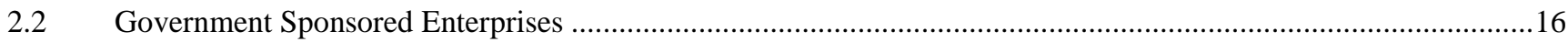

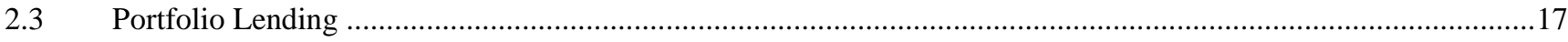

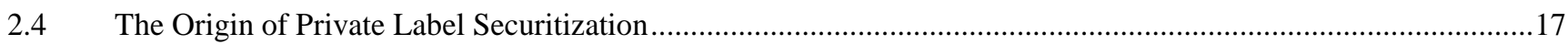

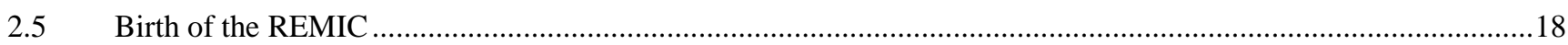

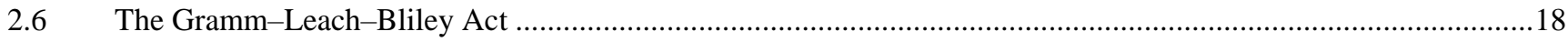

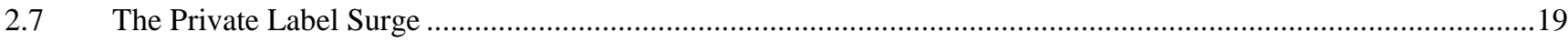

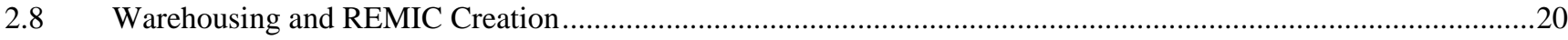

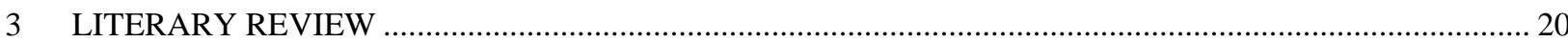

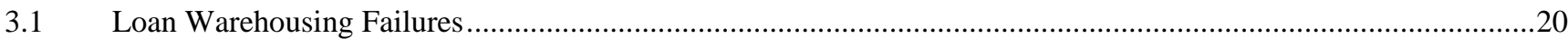

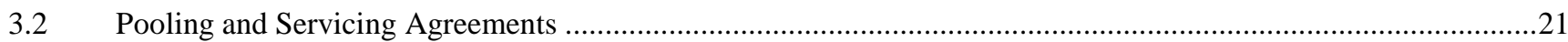

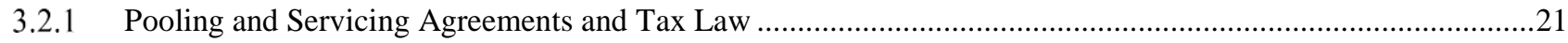

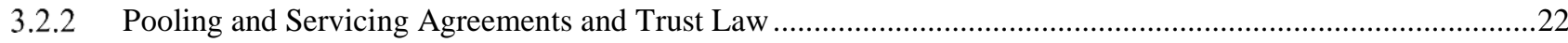

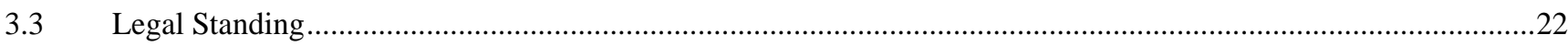

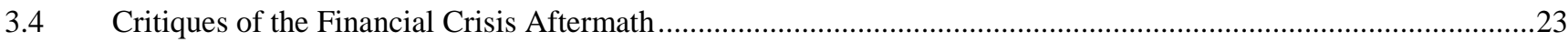

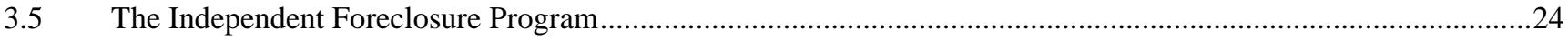

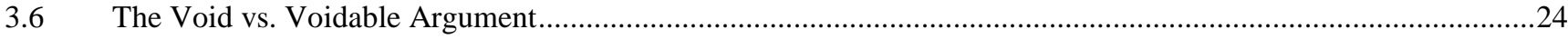

3.6.1 Homeowners Are Third Parties to Mortgage Assignments ...........................................................................25

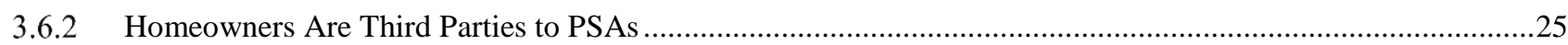

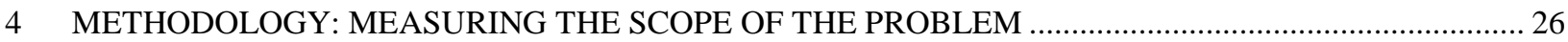

$4.1 \quad$ Screening for Void (as opposed to merely "voidable") Assignments ……......................................................26

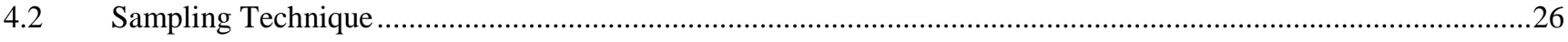

4.2.1 Figure 1. Sample Area. Source: http://gis.snoco.org/maps/permits/viewer.htm .............................................27

4.2.2 Figure 2. Search Criteria: "Notice of Trustee's Sale" ....................................................................................28

4.2.3 Figure 3. Search Results for "Notice of Trustee's Sale" ................................................................................29

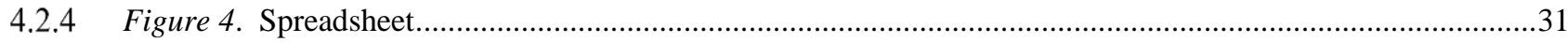

4.2.5 Figure 5. Example of a Rogue Assignment …….......................................................................................32 
5.1 Results and Interpretation

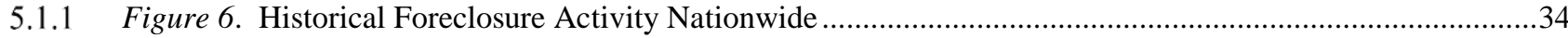

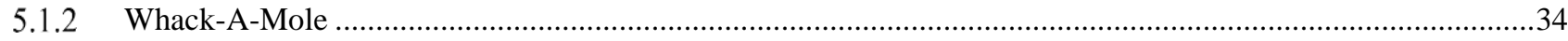

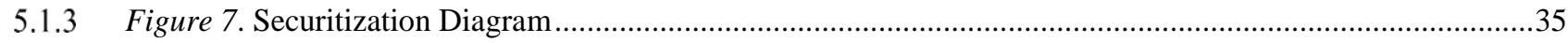

5.1.4 Figure 8. Distinguishing Between a Legitimate REMIC and a Rogue REMIC .............................................36

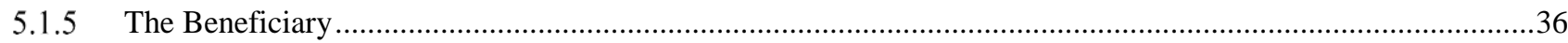

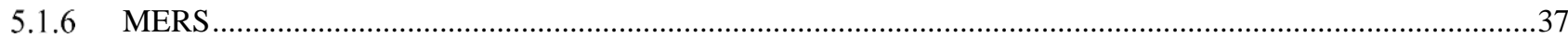

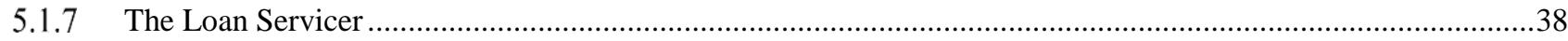

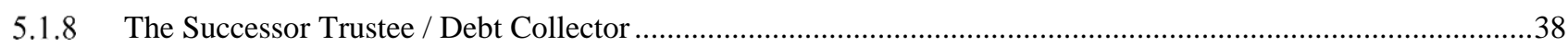

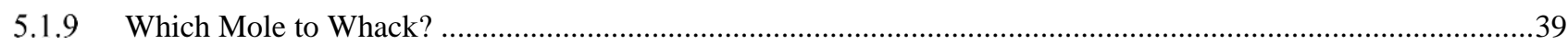

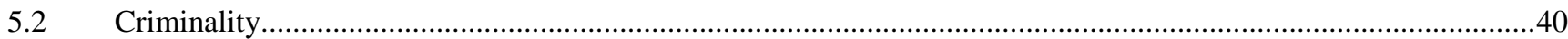

5.2.1 RCW 9.38.020 False representation concerning title. .....................................................................40

5.2.2 RCW 40.16.030. Offering false instrument for filing or record: .......................................................40

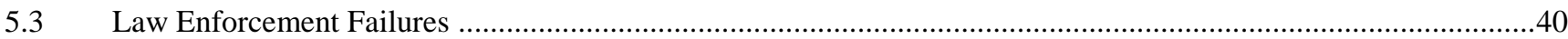

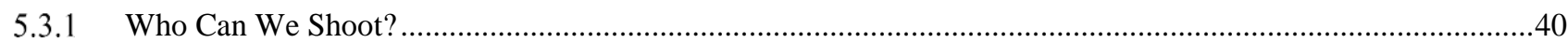

5.3.2 The First Line of Defense against Rogue REMICs: County Auditor........................................................43

5.3.3 The Second Line of Defense Against Rogue REMICs: County Prosecuting Attorney .................................43

5.3.4 The Third Line of Defense against Rogue REMICs: State Attorney General..............................................44

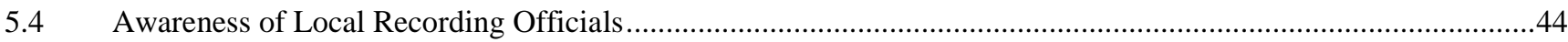

5.4.1 Southern Essex County, Massachusetts ...............................................................................................44

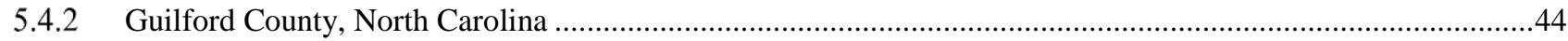

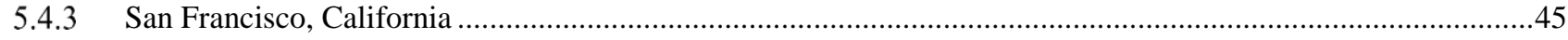

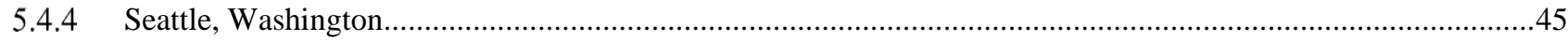

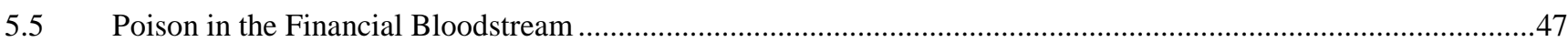

5.5.1 Abdication of Responsibility by Public Officials.............................................................................47

5.5.2 RCW 9A.08.010 General requirements of culpability. ........................................................................47

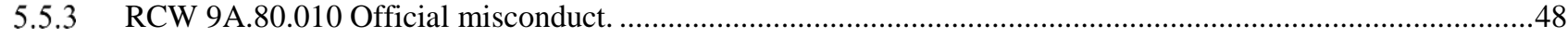

5.5.4 RCW 42.20.100 Failure of Duty by Public Officer a Misdemeanor. ...........................................................48

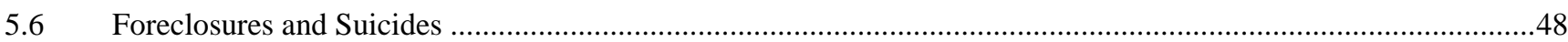

5.6.1 Figure 8. Frequency of Suicides Associated With Eviction or Foreclosure ..............................................49

5.6.3 Figure 9. Assignment from MERS to Bank of New York Mellon (Phyllis Walsh) ........................................51

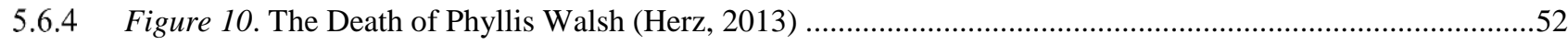

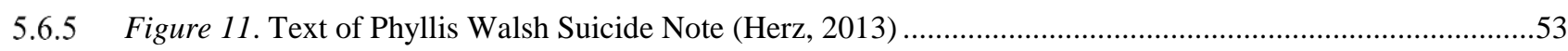


APPENDIX A 04.10.2013 Letter to Ben Bernanke 63

APPENDIX B 07.06.2015 Letter to Snohomish County Auditor ......................................................................... 74

APPENDIX C 07.14.2015 Letter from Snohomish County Auditor ......................................................................... 77

APPENDIX D 07.30.2015 Letter to Snohomish County Prosecuting Attorney ....................................................... 78

APPENDIX E 08.05.2015 Letter from Snohomish County Prosecuting Attorney ................................................... 79

APPENDIX F 08.17.2015 Letter to Snohomish County Prosecuting Attorney ........................................................ 80

APPENDIX G 08.26.2015 Letter from Snohomish County Prosecuting Attorney ..................................................... 81

APPENDIX H 09.08.2015 Letter to Snohomish County Prosecuting Attorney ........................................................... 82

APPENDIX I 09.26.2015 Online Message to Washington Attorney General ........................................................... 84

APPENDIX J 10.07.2015 Online Response from Washington Attorney General ...................................................... 85

APPENDIX K 10.26.2015 Letter to Washington Attorney General............................................................................ 86

APPENDIX L 11.09.2015 Online Message from Washington Attorney General .................................................... 89

APPENDIX M 04.12.2016 Online Message to Washington Attorney General ........................................................ 90

APPENDIX N 04.26.2016 Online Message From Washington Attorney General ................................................... 91

APPENDIX O 04.26.2016 Online Message to Washington Attorney General .......................................................... 92

APPENDIX P 05.21.2016 Message to AG and Prosecutors of King and Snohomish Counties ................................ 92

APPENDIX Q 05.23.2016 Online Message from Snohomish Prosecuting Attorney ................................................ 93

APPENDIX X IRS CODE 26 U.S.C. §§ 860A-860G (REMICs) ..................................................................... 94

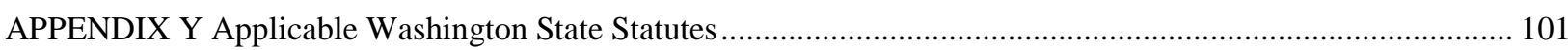

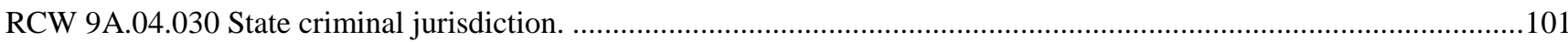

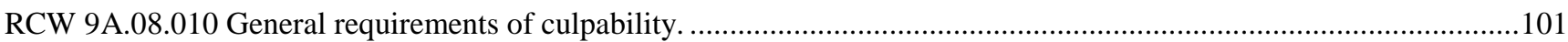

RCW 9A.72.080 Statement of what one does not know to be true..................................................................................101

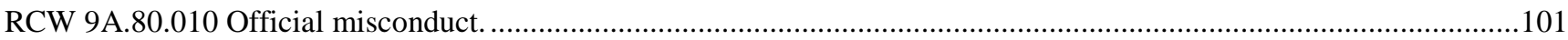

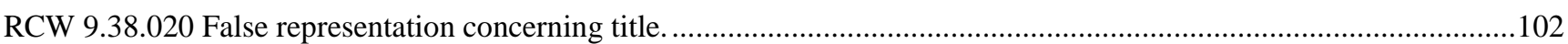

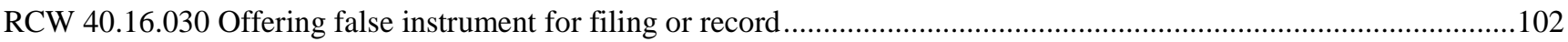

RCW 42.20.100 Failure of duty by public officer a misdemeanor. .........................................................................102

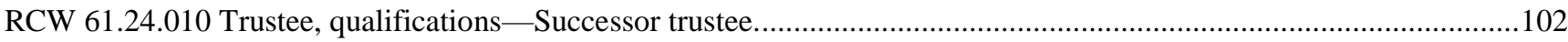

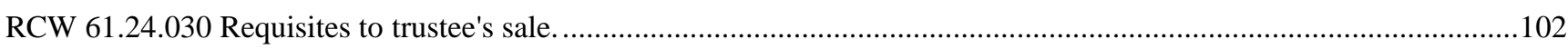

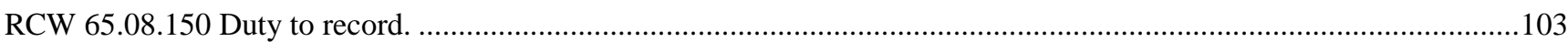

Appendix Z New York State Trust Law .....

103 


\section{INTRODUCTION}

\subsection{Statement of the Problem}

Do foreclosures by entities with no legal standing to do so constitute a public policy failure?

\subsection{How did We Get Here?}

In the seven years between the repeal of the Glass-Steagall Act and the Great Recession (between 2000 and 2007), reduced mortgage loan qualification standards for borrowers, coupled with innovations in mortgage loan financing (most notably: private label REMICs), sustained a borrowing/lending binge in the residential real estate market. Easy lending and borrowing fueled a demand for residential real estate which, in turn, caused an inordinate run-up (bubble) in housing prices. When the bubble burst in 2008, there was a significant decline in home values accompanied by a substantial increase in home foreclosures. Although most of those home foreclosures were legitimate, some may have involved fake or forged mortgage assignments to certain private label real estate mortgage investment conduits (herein: "Rogue REMICs" or "Rogues"). This is not just a problem of the past. It is a problem of the present as well because Rogue REMICs are still foreclosing on homes in the present day. This Inquiry will attempt to quantify the problem.

\subsection{Key Definitions}

\section{Assignment}

When a lender sells a loan, it assigns the trust deed to the buyer. "Assignment" means to convey a claim or a right to another party, known as the "assignee." This is done by creating another legal document — the assignment of trust deed — and having it signed by both buyer and seller. The trust deed, and other documents associated with the loan, become the property of the buyer. (Streissguth, T., n.d.) 


\section{Closing Date}

The date after which no additional loans can legally be assigned to a REMIC.

(See: Pooling and Servicing Agreement)

\section{Collateralized Debt Obligation (CDO)}

A type of structured asset-backed security (ABS). Originally developed for the corporate debt markets, over time CDOs evolved to encompass the mortgage and mortgage-backed security ("MBS") markets.

\section{Credit Bid}

An auction bid whereby the bidder, who claims to be owed a certain amount of money, is allowed to substitute that amount in lieu of cash.

\section{Credit Default Swap}

A financial instrument similar to premium payments on an insurance policy. A CDS is designed to transfer the credit exposure of fixed income products between two or more parties. The buyer of the swap makes payments to the swap's seller up until the maturity date of a contract. In return, the seller agrees that, in the event that the debt issuer defaults, the seller will pay the buyer the security's premium as well all interest payments that would have been paid between that time and the security's maturity date. A credit default swap is the most common form of credit derivative and may involve municipal bonds, emerging market bonds, mortgage-backed securities or corporate bonds. (Credit Default Swap - CDS, n.d.) 


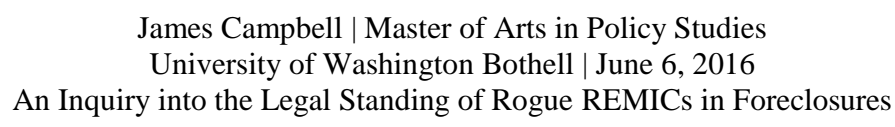

\section{Deed of Trust}

A document that embodies the agreement between a lender and a borrower to transfer an interest in the borrower's land to a neutral third party, a trustee, to secure the payment of a debt by the borrower. (Deed of Trust, n.d.)

\section{Lender}

See Loan Originator.

\section{Limbo Loans}

Loans with documentation deficiencies resulting in the absence of clear legal claims on the collateral. (Allen, Linda, 2011)

\section{Loan Originator}

Loan origination is the process by which a borrower applies for a new loan, and a lender processes that application. Origination generally includes all the steps from taking a loan application up to disbursal of funds.

\section{Loan Pool}

A combination of similar mortgages used as collateral for loans or for participation certificates sold to investors. 


\section{Loan Servicer}

The administration aspect of a loan from the time the proceeds are dispersed until the loan is paid off. This includes sending monthly payment statements and collecting monthly payments, maintaining records of payments and balances, collecting and paying taxes and insurance (and managing escrow and impound funds), remitting funds to the note holder, and following up on delinquencies.

\section{Master Loan Schedule}

A list of all loans which comprise the assets of a REMIC.

\section{Non-judicial Foreclosure}

A foreclosure that is conducted by private, for-profit enterprises without judicial oversight.

\section{Notice of Default}

Under Washington State law, you must be issued a Notice of Default and a Notice of Trustee Sale before the subject property could be auctioned.

\section{Pooling and Servicing Agreement (PSA) (also see: "Closing Date")}

The contract that governs the relationship between the various parties in the securitization process (REMIC) and controls what can and cannot be done with the trust. The PSA will state (among other things):

- the exact steps needed to create a trust

- how bundled mortgage loans are transferred into the trust 
- how securities are issued

- the duties, rights, and obligations of each party.

A typical PSA is worded, in part, as follows: "As promptly as practicable after any transfer of a Mortgage Loan under this Agreement, and in any event within thirty days after the transfer, the Trustee shall (i) affix the Trustee's name to each assignment of Mortgage, as its assignee, and (ii) cause to be delivered for recording in the appropriate public office for real property records the assignments of the Mortgages to the Trustee. (Loftsgordon, n.d.)

\section{Private Label Securitization}

Loan securitization that is conducted by private banking institutions and are unaffiliated with loans guaranteed by the U.S. government.

\section{Pro se litigant}

A party in a legal action who is unrepresented by an attorney.

\section{Quant}

Quantitative Analyst.

\section{Quiet Title}

A proceeding to establish an individual's right to ownership of real property against one or more adverse claimants. An action to quiet title is a lawsuit filed to establish ownership of real property (land and buildings affixed to land). The plaintiff in a quiet title action seeks a 
court order that prevents the respondent from making any subsequent claim to the property.

Quiet title actions are necessary because real estate may change hands often, and it is not always easy to determine who has title to the property.

\section{Regulatory Capture}

A theory associated with George Stigler, a Nobel laureate economist. It is the process by which regulatory agencies eventually come to be dominated by the very industries they were charged with regulating. Regulatory capture happens when a regulatory agency, formed to act in the public's interest, eventually acts in ways that benefit the industry it is supposed to be regulating, rather than the public.

\section{REMIC}

Real Estate Mortgage Investment Conduit. Investment vehicles that hold commercial and residential mortgages in trust and issue securities representing an undivided interest in these mortgages.

\section{Robo-signing:}

Refers to a variety of practices. It can mean a qualified executive in the mortgage industry signs a mortgage affidavit document without verifying the information. It can mean someone forges an executive's signature, or a lower-level employee signs his or her own name with a fake title. It can mean failing to comply with notary procedures. In all of these cases, robosigning involves people signing documents and swearing to their accuracy without verifying any of the information. (2011, Associated Press) 


\section{Rogue REMIC}

An unpopulated or partially populated REMIC. It is a REMIC which never did hold any or all of the commercial and residential mortgages that its trustee claimed to have held when the REMIC was created, but were nevertheless sold to the public in shares with the false representation that the REMIC was totally secured by mortgage loans.

\section{Startup Day}

The day on which the REMIC issues all of its regular and residual interests.

26 U.S. Code $§ 860$ G(a)(B)(9) (APPENDIX X)

\section{Successor Trustee}

In the context of trust deeds, a trustee which replaces the trustee that is identified on the original deed of trust

\section{Township}

A small geographic area. Townships range in size from 6 to 54 square miles with 36 square miles ( 6 miles x 6 miles) being the norm

\section{Warehouse Lending (Warehousing)}

A line of credit extended by a financial institution to a loan originator to fund a mortgage that a borrower initially used to buy a property. The loan is typically warehoused from the time it 
is originated to when the loan is sold into the secondary market, whether directly or through a securitization. (Warehouse Lending, n.d.)

\subsection{Key Acronyms}

CDS Credit Default Swap

CDO Collateralized Debt Obligation

DOT Deed of Trust

FDIC Federal Deposit Insurance Corporation

IB Investment Bank

PSA Pooling and Servicing Agreement

SEC Securities and Exchange Commission

TBTF Too Big To Fail

\subsection{Chapter Summaries}

Chapter 2 discusses the history of loan securitization in the $20^{\text {th }}$ century. The origins can be traced to the New Deal, part of which involved restoring stability to the housing market during the Great Depression. Many bank failures during the 1930s are attributable to home foreclosures. The surviving banks were reluctant to return to mortgage lending; and so the federal government incentivized the banks by guaranteeing repayment in the event of borrowers' payment default. By 1938, the Feds were not only insuring loans; they were buying them outright. Rather than being a taxpayer-funded subsidy, the policy of buying loans from banks turned out to be profitable to the government for decades to come. By the 1970's Wall Street investment bankers decided that if the government could consistently profit from the mortgage market, they could too. And so for the final 30 years of the twentieth century, these 
banks not only went into competition for those profits with the U.S. government, they ultimately devised a financial instrument to maximize them: the "private label" real estate investment conduit (REMIC). But where there's profit, there's greed. In the first decade of the $21^{\text {st }}$ century, greed in the mortgage market became so pervasive that it posed a systemic threat to the worldwide financial system.

Chapter 3, Literary Review, cites works of scholars and attorneys whose findings support the various arguments as to why Rogues have no legal standing to foreclose on any homeowners. Bradley Bordon and David Reiss, professors at the Brooklyn Law School are two of the more prolific authors on the subject. They share their profound insights into the multiple legal complications that result from the public policy of acquiescing to Rogue foreclosures. Their sentiments are shared by Georgetown Law Professor Adam Levitin. In the private sector, Roy Oppenheim, one of the more prominent Florida foreclosure defense attorneys, is in total agreement with his professorial counterparts. Together, these authors support the argument that because falsified assignments are void, so are the ensuing foreclosures.

Chapter 4, Methodology, focuses upon the research of Snohomish County records to determine what proportion of all foreclosures are perpetrated by Rogue REMICS. Upon determining that the proportion is significant, the Discussion (Chapter 5) focuses on the mechanics of how the Rogues manage to manipulate local businesses into assisting them with unlawful foreclosures. The Discussion chapter also addresses the various the difficulties that homeowners face when confronting a Rogue REMIC in foreclosure situations, which is made all the more difficult by the collective indifference and/or lack of understanding by state and local officials of how the Rogues manage to remain under the radar of law enforcement. The McDonnell Analytics report to the Seattle City Council (September, 2015) is also referenced in Chapter 5, as it appears to be the most thorough and current assessment of unlawful foreclosures locally. It is also duplicative, in many ways, to research I conducted in 
neighboring Snohomish County concerning foreclosure starts for that same study year: 2012. Social ramifications, suicides in particular, are also addressed in Chapter 5.

\section{BACKGROUND OF MORTGAGE LOAN SECURITIZATION}

In order to argue the absence of legal standing to foreclose by Rogue REMICS, it is first necessary to briefly outline the history of legitimate loan securitization in the U.S., how the evolution of this process led to the creation of REMICs; and how that evolution ultimately resulted in the proliferation of Rogue REMICs. That discussion begins with the financial reforms that were enacted during the Great Depression.

\subsection{The Great Depression and Insurable Loans}

The origins of mortgage loan securitization can be traced back to the financial reforms that were enacted when the U.S. was in the throes of the Great Depression. One of the most notable reforms of that era was the 1933 Glass-Steagall Act. This Act was primarily directed at prohibiting banks and their affiliates from underwriting or distributing securities. The reasoning behind it is straightforward: depositors' money placed in a bank for safekeeping should never be used to make speculative bets by those banks with the money entrusted to them. Senator Glass, Representative Steagall, and others alleged that banks had placed depositors' money at unreasonable risk by allowing them to use it to invest in high risk securities (Carpenter, 2013, Summary). After that, there were essentially two types of banks: investment banks and commercial banks. The former could invest in high risk ventures like stocks and business start-ups; the latter needed to stick to safer, mostly collateralized investments such as mortgages and auto loans.

During that same era, as part of FDR's New Deal, the National Housing Act of 1934 created the Federal Housing Administration (FHA) to assist in the construction, acquisition, and/or rehabilitation of 
residential properties (Fabozzi, 1992, p. 18-19). Part of the FHA mandate was to assess the credit worthiness of mortgage loan applicants. Those who met the FHA's credit criteria were deemed "insurable" by the federal government; meaning that the government would guarantee repayment of the loan to the commercial bank if the borrower failed to meet the terms and conditions of the mortgage.

\subsection{Government Sponsored Enterprises}

In 1938, the federal government created the government-sponsored corporation: Federal National Mortgage Association (Fannie Mae). Its purpose was to use taxpayer money to buy conforming (meaning qualified borrowers') mortgages from private lenders (commercial banks, generally). This process would free up cash so that the banks could make more loans. Fannie was sold to private shareholders in 1968 but its original mandate remained unchanged. What did change, in 1970, was that Fannie Mae may was able to securitize its mortgages and sell shares of them in the open market (History of, n.d.) Soon after the sale of Fannie, the feds created the Federal Home Loan Mortgage Corporation (Freddie Mac) which was originally mandated to buy loans exclusively from saving and loan associations (Katz, 2009, pp. 236-237). Like the FHA and Fannie, Freddie's purpose was to encourage home ownership by providing liquidity to the mortgage market. Together Freddie and Fannie were dubbed Government-Sponsored Enterprises (GSEs). Unlike the FHA, Fannie and Freddie loans were never explicitly insured by the federal government; although there was always an implicit government guarantee from the perspective of the investment community.

GSEs, with their direct access to U.S. Treasury, have historically been able to borrow money at lower interest rates than banks. This meant that they could and did charge borrowers lower interest rates than commercial banks. GSE loans were therefore the most popular choice among mortgage borrowers throughout the post-depression $20^{\text {th }}$ century. 


\subsection{Portfolio Lending}

Due to GSE conformity standards, not all borrowers could qualify for GSE loans. These folks were shut out of that market. Some people wanted loans which exceeded the GSE maximums. Others had dubious credit records. Still others, like the self-employed, were considered risky prospects with regard to current and future income. But that did not mean they were un-financeable. It just meant that their loans would be more expensive because there was no explicit, or even implicit guarantee of repayment provided by the feds. Yet there was and still is a robust (albeit much smaller) market for portfolio loans: ones that were kept on the books of the lending bank.

\subsection{The Origin of Private Label Securitization}

Even though commercial banks could earn decent profits through portfolio lending, they did share a common incentive with the federal government: to create liquidity so that more loans could be made. In 1977, Bank of America (BOA), a commercial bank, pioneered mortgage-backed securities (MBS). BOA's concept was to sell their portfolio loans to investment banks which would in turn package those loans into securities which, after being registered with the Securities and Exchange Commission could sell shares in them. This process created the revolving liquidity necessary to fund more such loans. Other major banks soon followed BOA's lead (Fabozzi, 1992, p. 31). However the market demand for these high-yielding shares was limited. Lacking insurance against defaults backed by the federal government (whether implicit or explicit) and being somewhat illiquid, shares of securities consisting of uninsured loans were still too risky for most investors. Their efforts to sell such shares were further stymied when Fannie started doing the same thing in the 1980s (Katz, 2009, p. 236). In response to the GSE's entry into loan securitization, the major commercial banks devised a scheme, based upon tax relief, to make their mortgage backed security shares more competitive with GSE shares. 
After doing so, they dispatched lobbyists to Washington to get some changes in federal taxation. They succeeded by helping Congress write and pass the REMIC law in 1986.

\subsection{Birth of the REMIC}

Part of Tax Reform Act of 1986 included the REMIC law - IRS CODE 26 U.S.C. $§ \S 860 A-$ 860G (APPENDIX X), referring to Real Estate Mortgage Investment Conduits. As the name suggests, a REMIC is a direct money pipeline between borrowers and lenders. The primary reason for the creation of this law, according to the banking industry, was to level the playing field on which private label MBSs were competing with GSE MBSs. "By June, 1983, the government agencies had issued almost $\$ 230$ billion in mortgage-backed securities, while the purely private sector had issued only $\$ 10$ billion" (McLean, 2010, p. 13).

\subsection{The Gramm-Leach-Bliley Act}

In the 1990s, along with the advent of the internet and the ceaseless pressure on Congress by the banking industry, the separation of commercial banking from investment banking was coming under increasing scrutiny by the banking community. The general argument from their perspective was that this separation was antiquated and not in tune with modern finance. By 1999, the banking industry finally got Congress to agree. The Gramm-Leach-Bliley Financial Modernization Act (GLBA) was enacted by Congress that year which repealed Sections 20 and 32 of the Glass-Steagall Act. The GLBA put an end to the separation between commercial and investment banks which effectively reinstated the ability of commercial and investment banks to recombine (and repeat the mistakes of the 1920s). There is no discernable difference between what happened with loosely regulated banks in the 1920s and what happened between 2000 and 2007, following the passage of the GLBA... except for one. Whereas the bank depositors in the 1920s were at risk for losses due to bad investments by the bank, that risk was virtually eliminated in the 1930s with the creation of the Federal Deposit Insurance Corporation (FDIC). 
The upshot of that policy change was that the risk of loss to depositors due to poor investment decisions by commercial banks that existed in the 1920 s was transferred to the taxpayers.

After the passage of the GLBA, investment banks and commercial banks were once again allowed to comingle their assets, which resulted in a flurry of bank mergers between the two, which in turn created the financial behemoths that exist today. The combined banking institutions rapidly became big enough to create the troubling current environment of regulatory capture.

\subsection{The Private Label Surge}

Once Glass Steagall was repealed, the combined Wall Street investment/commercial banks directed their quants to devise private label REMICs which were unfettered by the regulations that governed GSE securities. Every REMIC had certain features and provisions that are common to all of them: Pooling and Servicing Agreements (PSAs) that invariably require the following procedure, according to Borden \& Reiss (2012), to be executed timely and in this exact order:

The borrowers execute a mortgage notes in favor of the originator for the amount of the loan and grant the originator a mortgage on the residence. The originator records the mortgages in the county clerk's office. The originator sells the mortgage notes and assigns the mortgage to a REMIC sponsor. The sponsor records assignments of mortgages in the county clerk's office. The sponsor transfers the mortgages notes and assigns the mortgage to a REMIC trust in exchange for beneficial interests in the trust. The REMIC trustee records the assignment of the mortgage, and the sponsor sells the beneficial interests to investors. (p. 2)

Loan origination and loan securitization are not simultaneous processes. The creators of mortgage backed securities need some time to assemble qualified mortgages to be components of REMICs. Thus there is a lag between the time that a mortgage is issued and the time that it must be packaged into a security and sold to investors. This is euphemistically referred to as "warehouse" time. 


\subsection{Warehousing and REMIC Creation}

In practice, loan warehousing operates more like a factory than a warehouse. Loan originators draw down their warehouse credit lines established with investment banks to make loans and, after a mortgage is recorded in the local County, replace the cash with the mortgages that they fund. Once the loan is sold in the secondary market (to a REMIC, for example), the investment bank then restores the value of the mortgage to the originator's credit line. The originator can then repeat the process. It is incumbent upon the involved principals, by both trust and IRS law, to conduct this process properly and timely. Legal scholars who have thoroughly analyzed mortgage securitization requirements concur that warehousing failures can and have destroyed the legal standing of foreclosing REMICs. Warehousing failures is the starting point for Chapter 3: Literary Review.

\section{LITERARY REVIEW}

\subsection{Loan Warehousing Failures}

The warehouse is not only the place where REMICS are created. It is where individual loans are permanently packaged (pooled) into a monolithic financial entity. Once a loan is assigned to a given REMIC, that is where it resides permanently, until it is retired, along with all the other loans in the REMIC pool. And once that assignment occurs, in accordance with every REMIC PSA, the document that memorializes the transfer must be contemporaneously recorded in the county where the secured property is located. That did not always occur during the run-up to the financial crisis. Levitin (2013) argues that in many instances, the warehouse activities that were supposed to combine mortgages into pools never occurred. Worse still, because of the sheer volume of loans being processed, some loans may have been sold to multiple buyers (p. 700). Oppenheim (2012) suggests that because the assignments to old REMICs that are executed and recorded years after they had been closed is 
"undeniable evidence" that the transfers never occurred (pp. 761-762). But even when this undeniable evidence comes to light, such as when a REMIC starts a foreclosure before a bogus assignment even occurs, the Rogue's only punishment is cancellation of the foreclosure (Borden and Reiss, 2013-1, p.6) In 2014, as Senior Counsel for the National Association of Insurance Commissioners Robert Carcano concurred with the uncomplicated premise that belated assignments are bogus and cannot be relied upon as a pretext for a foreclosure (Carcano, 2014, p.3)

\subsection{Pooling and Servicing Agreements}

Typically, a REMIC trustee is responsible to ensure that payments from mortgage loan borrowers are properly directed back to the REMIC for the benefit of the investors in strict accordance with the PSA. Adam J. Levitin, \& Tara Twomey (2011-1) argued that: "In a foreclosure filed by a trustee on behalf of a securitized trust, the PSA is the key piece of documentation needed from the bank in order for the judge to determine whether the trust owns the loan being foreclosed" (pp. 31-32). Oppenheim (2012) noted that the prospectuses of any REMIC, which include the pooling and servicing agreements, can be located at the website of the Securities and Exchange Commission. He also noted that each of the prospectuses make reference to a Master Loan Schedule (the list of loans which comprise the pool of mortgages). But the actual list of loans cannot be found there. That is not information that is available to the public. "The Master Loan Schedule establishes whether the subject mortgage was ever transferred to that particular trust (p. 757)". (Emphasis in original text)

\subsubsection{Pooling and Servicing Agreements and Tax Law}

When properly constructed and maintained, private label REMICs pay no income taxes on the cash flows from mortgage loan borrowers to investors (interest payments). The tax burden is borne entirely by the investors; and the REMIC itself is not taxed. The REMIC is merely an income "conduit" which, when properly constructed and managed, eliminates the double-taxation that normally occurs 
when corporate profits (which are taxed) are distributed to shareholders (and taxed again). During the warehouse phase, securities in REMICs may be sold to the public before the individual mortgages on the Master Loan Schedule are recorded locally. This is allowed under IRS rules but every individual recording must be accomplished within 90 days after the startup date of the REMIC (Oppenheim, 2012, p. 758); (Rehrauer, 2010, p. 12). Any REMIC that fails to strictly conform to the IRS REMIC law is (according to the law as written) liable for a $100 \%$ tax penalty equal to the entirety of income earned by the REMIC. 26 U.S. Code $\S 860 F(a)(1)$ (APPENDIX X)

\subsubsection{Pooling and Servicing Agreements and Trust Law}

In order to not run afoul of REMIC tax laws, typical PSAs specify 30 days for completing REMIC pools; leaving a 60-day leeway to allow time to correct any unforeseen securitization issues. This shortened timeframe is a tacit acknowledgement by REMIC creators that tax law is not a matter to be trifled with. Neither is trust law. Levitin, (2011) explains that REMIC trusts are also governed by New York law as it applies to trusts. Any transfer to a trust in contravention of the trust documents is void. Regarding REMICs, the 30-day rule contained in the PSA supersedes the 90-day IRS rule. (p. 14, FN 35); (See: APPENDIX Z).

\subsection{Legal Standing}

In the modern era, The U.S. Supreme Court settled the standing matter in 1972 in Sierra Club v.

Morton. In this case, the Walt Disney Company proposed to build a new ski resort in northern California and for access, it proposed to build a highway through Sequoia National Forest. Stewardship of National Forests comes under the jurisdiction of the U.S. Department of the Interior. The Sierra Club sued Rogers Morton, who was Secretary of the Interior at the time, to block construction of the highway. The Club contended that such construction would despoil the wilderness ecology of the region and that the Interior Department had failed to exercise its authority to prohibit such development. Ultimately, the 
U.S. Supreme Court decided the Club lacked standing to have the court adjudicate the matter because no particular person was named as a harmed plaintiff. Only the Club itself was named and the club is not a person. In the absence of naming such an individual, the Club failed the "threshold" test euphemistically meaning that the Club would not be allowed to pass through the entrance door of the court to have its grievance decided.

Because standing is a threshold question, courts have stated that a defect in standing cannot be waived; it must be raised, either by the parties or by the court, whenever it becomes apparent" (Froehle, 2011, pp. 1729 -1730, FN 57-61). Legal Standing in the context of loan securitization is subject to a similar threshold question. If a borrower's loan did not leave the "warehouse" timely (if ever) to be incorporated into any REMIC, which includes memorializing that transfer in the local county, the REMIC trustee cannot create standing years later by filing a bogus assignment. As Levitin (2010) explains that "Securitization is the legal apotheosis of form over substance, and if securitization is to work it must adhere to its proper, prescribed form punctiliously" (p. 3).

\subsection{Critiques of the Financial Crisis Aftermath}

An anonymous Wall Street Journal author wrote a brief and somewhat tongue-in-cheek article entitled The Politics of Foreclosure on October 9, 2010 which began thusly:

Talk about a financial scandal. A consumer borrows money to buy a house, doesn't make the mortgage payments, and then loses the house in foreclosure only to learn that the wrong guy at the bank signed the foreclosure paperwork. Can you imagine? The affidavit was supposed to be signed by nameless, faceless employee in the back the office who reviewed the file, not the other nameless, faceless employee who sits in the front. (Politics of Foreclosure, 2010, Section A, p.14) 
In this article, Anonymous went on to suggest that if a borrower has fallen behind in his/her payments, it does not matter whether or not the foreclosing entity needs to prove ownership of the loan that is being foreclosed. What is more important, according to Anonymous, is that the housing market must be allowed to recover for the overall good of the economy. Foreclosures must proceed quickly and efficiently; and homeowners in arrears should not be allowed to game the system while living in their homes for free. The absence of legal standing of foreclosing entities is irrelevant to Anonymous.

\subsection{The Independent Foreclosure Program}

By 2011, federal regulators were well aware of the widespread allegations by homeowners of irregularities in loan documentation and foreclosure procedures. At the same time, however, these regulators knew that the business of banks and government policy had become inextricably connected. In that political-economic climate, and after protracted negotiations between the regulators and fourteen major loan servicers, the Independent Foreclosure Program (IFR) was publically announced in April, 2011 (Interagency Review of Foreclosure Policies and Practices, 2011). Legal standing to foreclose was on the agenda of this investigation; but the IFR was disbanded in January, 2014 without resolving any of the central questions as to whether peoples' homes were wrongfully threatened to be foreclosed upon, or actually foreclosed, including the question of legal standing (What You Need to Know: Independent Foreclosure Review, n.d.). Instead, the U.S. agencies which administered the IFR settled with the 14 banks under their scrutiny for a collective "punishment" of approximately $\$ 9.3$ billion, with no criminal prosecutions. This settlement essentially allowed the trustees of Rogue REMICs to continue foreclosing on peoples' homes into the indefinite future.

\subsection{The Void vs. Voidable Argument}

The void vs. voidable argument encompasses, among other documentation irregularities, the infamous robo-signing scandal that surfaced at the beginning of the foreclosure crisis. Some courts 
have since weighed in on whether the introduction of such documents in the course of a foreclosure defense is adequate to obtain a dismissal for lack of standing by a Rogue. For example if a document was robo-signed but would otherwise be valid if signed by a proper authority, then it is voidable. What this means is that a judge may be inclined to postpone a foreclosure, giving the foreclosing entity an opportunity to substitute a properly signed document. But this approach of attacking a voidable document can also backfire on the homeowner because, as previously mentioned, all parties to a litigation are subject to standing scrutiny at any time. This includes attacks on the legal standing of a homeowner. Two examples follow.

\subsubsection{Homeowners Are Third Parties to Mortgage Assignments}

A third party cannot assert rights or defenses under a contract that belong to another party... In the mortgage assignment context, this has led many courts to conclude that debtors do not have any standing to raise questions about the validity of mortgage assignments (Zacks, 2014-2015. p. 708).

\subsubsection{Homeowners Are Third Parties to PSAs}

A homeowner/mortgagor might challenge a Rogue's right to foreclose based upon its failure to strictly conform to the PSA requirements. In response, a Rogue might ask the courts to question whether homeowners have standing to challenge the terms of a PSA. Some courts have determined that a homeowner lacks standing to oppose a foreclosure on such grounds. "(P)laintiffs did not have standing to challenge an assignment to which they were not a party unless that assignment was void. Because the transfer of the Note, if indeed it violated the PSA, would merely be voidable, Plaintiffs [did] not have standing to challenge it" (Zacks, 2014-2015. p. 721. FN 94). 


\section{METHODOLOGY: MEASURING THE SCOPE OF THE PROBLEM}

\subsection{Screening for Void (as opposed to merely "voidable") Assignments}

Per the discussions in Section 3.6, one preliminary conclusion can be drawn: the legal standing of any REMIC to foreclose on a homeowner, so far as many courts have determined, is not necessarily destroyed if voidable documents were created somewhere in the title chain. Rather REMIC standing may be destroyed if one or more of those documents is void. If it can be demonstrated that the recorded assignment which purportedly vested foreclosure rights in a given REMIC is a void document, then the entire foreclosure process from that point forward is also void (not merely voidable). Foreclosures traceable to void assignments are Rogue foreclosures "making the $\mathrm{B} \rightarrow \mathrm{C} \rightarrow \mathrm{D}$ transfers meaningless; $\mathrm{B}$, and therefore C, have nothing to transfer" (Levitin, 2013 p. 700).

It is an unfortunate circumstance for any individual homeowner to be victimized by a Rogue foreclosure. But if such foreclosures are exceedingly rare rather than commonplace, then these isolated incidents would not present a public policy problem. That is also true of the reverse. So to establish whether or not Rogue foreclosures present a public policy problem in need of correction, it is first necessary to determine how prevalent they are.

\subsection{Sampling Technique}

I began the process of prevalence determination by developing a sampling technique which could be applied to a much larger population of the same variables (to make the process replicable) should a future researcher choose to do so. All of the variables featured in this Inquiry are documents of public record which can be found in most county databases. It is now common for U.S. counties to make images of these documents accessible via an online search of the county website. One such county is Snohomish, in the State of Washington. I identified a specific geographical study area in Snohomish County which I believe to be representative of a typical combination of suburbs and rural 
areas that might exist between two medium-sized U.S. cities. In this case, I chose an area that is about mid-way between Everett, WA and Seattle, WA. It is an area known in the parlance of real estate legal descriptions, as a series of "Townships". I confined my sampling to Township 27-3 through Township 27-13 of Snohomish County, WA. This is a cross-section of the County that encompasses the entirety of the southernmost 6 miles between its western and eastern boundaries (generally, a 54-mile wide swath of land between Puget Sound and the crest of the Cascade Mountain range respectively). Figure 1.

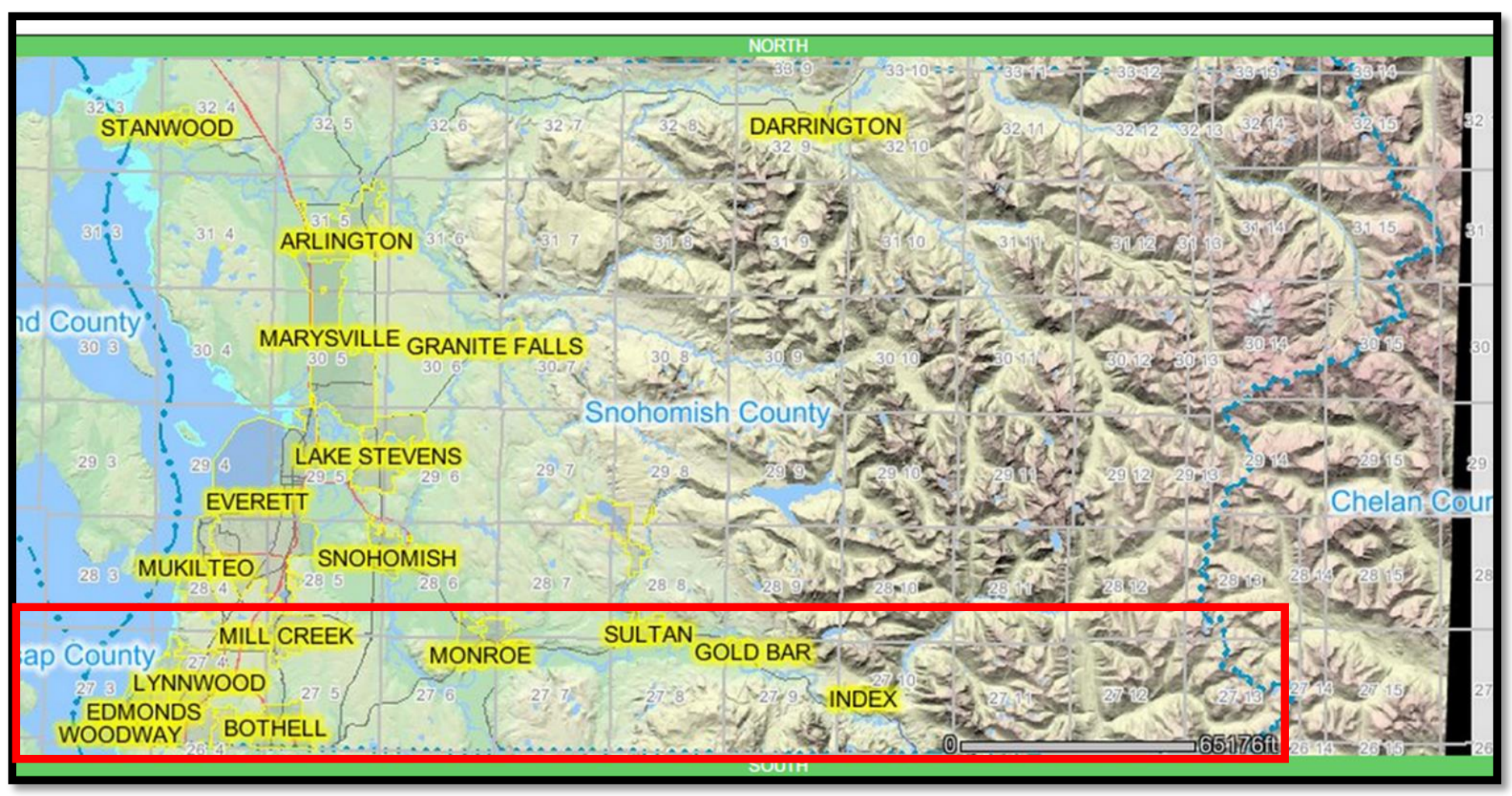

\subsubsection{Figure 1. Sample Area. Source: http://gis.snoco.org/maps/permits/viewer.htm}

I then accessed the Snohomish County Public Records database to determine how many non-judicial foreclosures were initiated (NOTICE OF TRUSTEE'S SALE) in these Townships during the entirety of calendar year 2012. Figures 2 \& 3. There were approximately 151 such Notices filed. All such notices 
feature the tax parcel number of the property. Next, by entering the tax parcel number in the appropriate search field, scanned images of all other documents of record pertaining to the property can be retrieved including such items as trust deeds, trust deed assignments and trustee substitutions.

Official Public Records

Search Criteria

Menu $\cdot$ Prefs . Help
Snohomish County, Washington

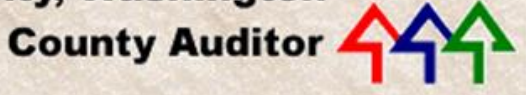

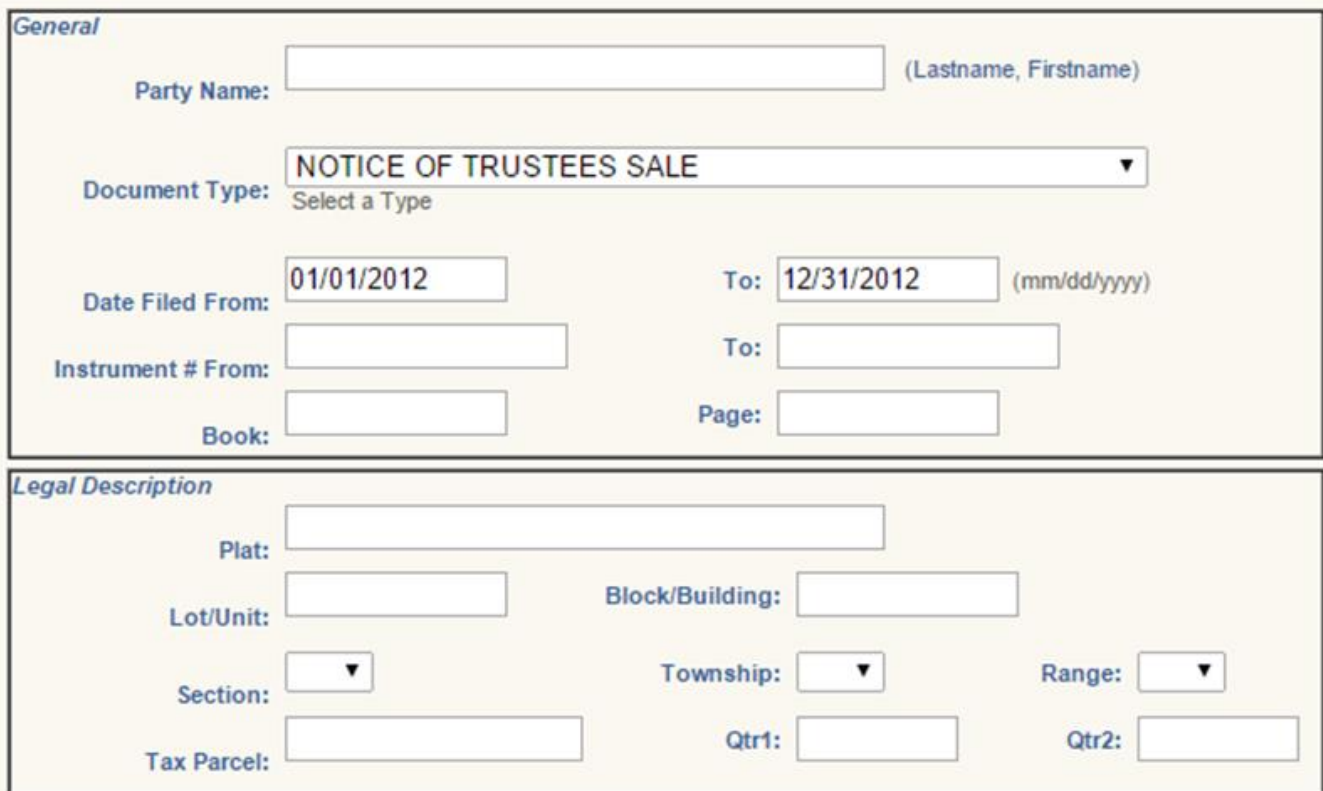

Search Clear Form

Permanent Index From 01/01/1976 to 02/20/2015

Temporary Index From 02/23/2015 to 03/06/2015

Images From 07/01/1997

\subsubsection{Figure 2. Search Criteria: "Notice of Trustee's Sale"}




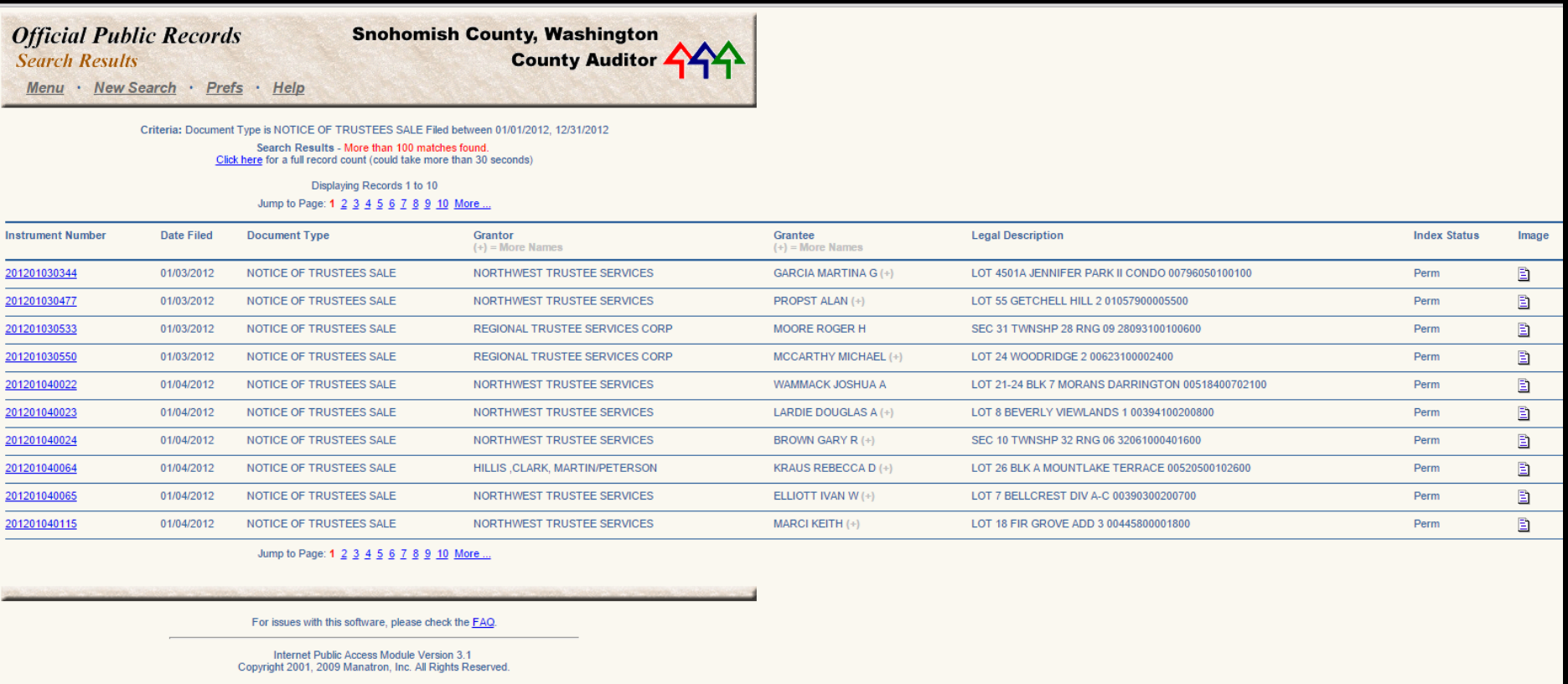

\subsubsection{Figure 3. Search Results for "Notice of Trustee's Sale"}

After collecting pertinent data from the Snohomish County database, the research findings were entered on a spreadsheet (see: figure 4. Spreadsheet and Supplement 1) and analyzed to detect a particular sequence of events that is common to all Rogue foreclosures, while filtering out those foreclosures that do not conform (do not involve Rogues). That five-part, chronologically ordered sequence is as follows:

1. Was there an ASSIGNMENT OF DEED OF TRUST document recorded against the property in the county where the subject property is located? If the answer is "no", the sample was eliminated from the sample population.

2. Was the assignee a trustee of a REMIC? If the answer is "no", the sample was eliminated from the sample population.

3. Was the REMIC closed prior to the execution of the ASSIGNMENT? This can determined by the year in which the REMIC was created. That Year is contained in the 
name of the assignee (see: Figure 5 Example of Rogue Assignment). If the answer is "no", the sample was eliminated from the sample population.

4. Did the trustee of this REMIC subsequently cause an APPOINTMENT OF SUCCESSOR TRUSTEE document to be recorded against the property (after an assignment to a Rogue, the Rogue always replaces the original trustee with a non-neutral foreclosure specialist)? If the answer is "no", the sample was eliminated from the sample population.

5. Did the SUCCESSOR trustee subsequently cause a NOTICE OF TRUSTEE'S SALE to be recorded? If the answer is "no", the sample was eliminated from the sample population. 


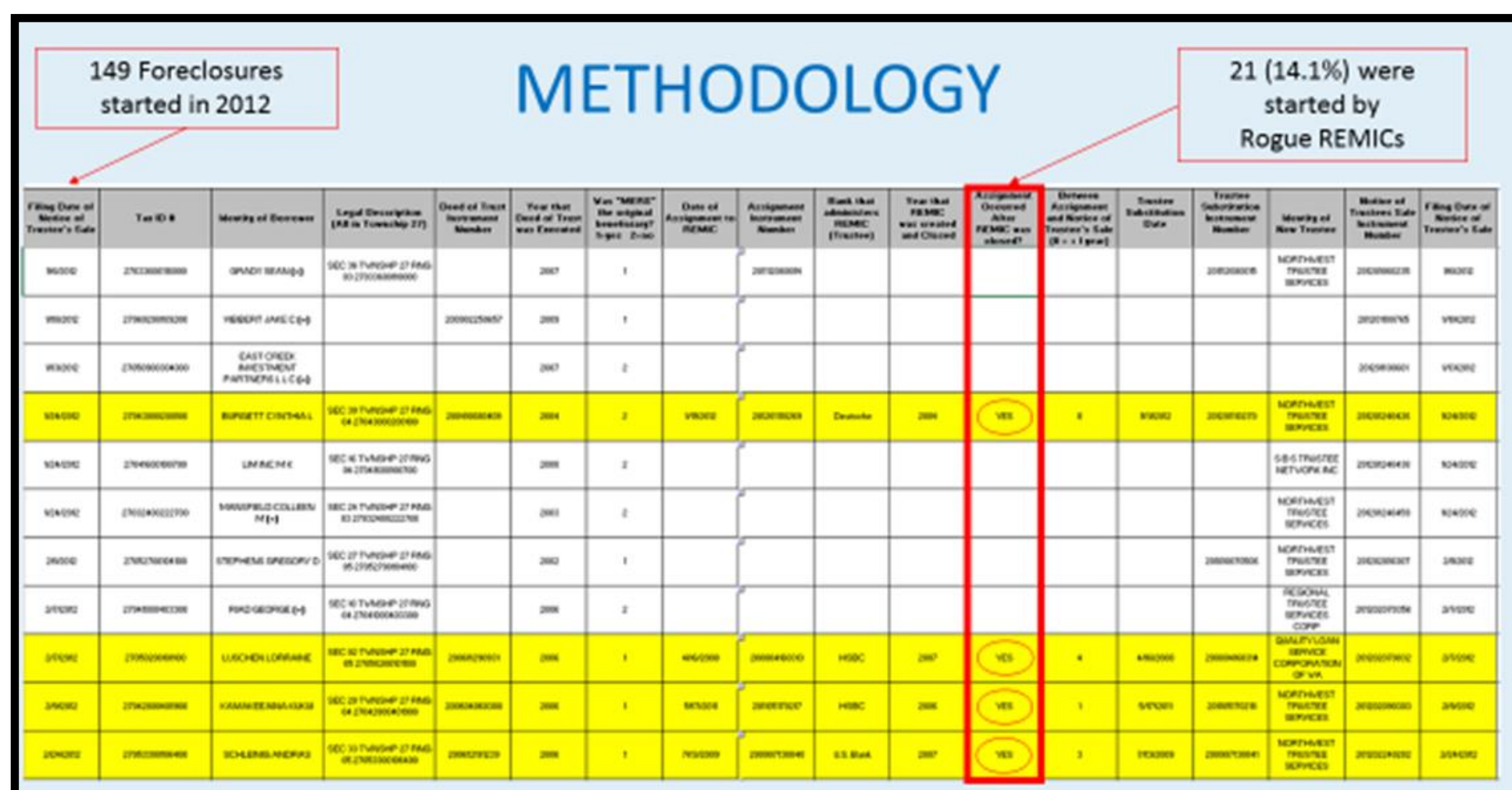

In $2012,14.1 \%$ OF ALL FORECLOSURES WERE BEGUN BY ROGUE REMICS.

\subsubsection{Figure 4. Spreadsheet}



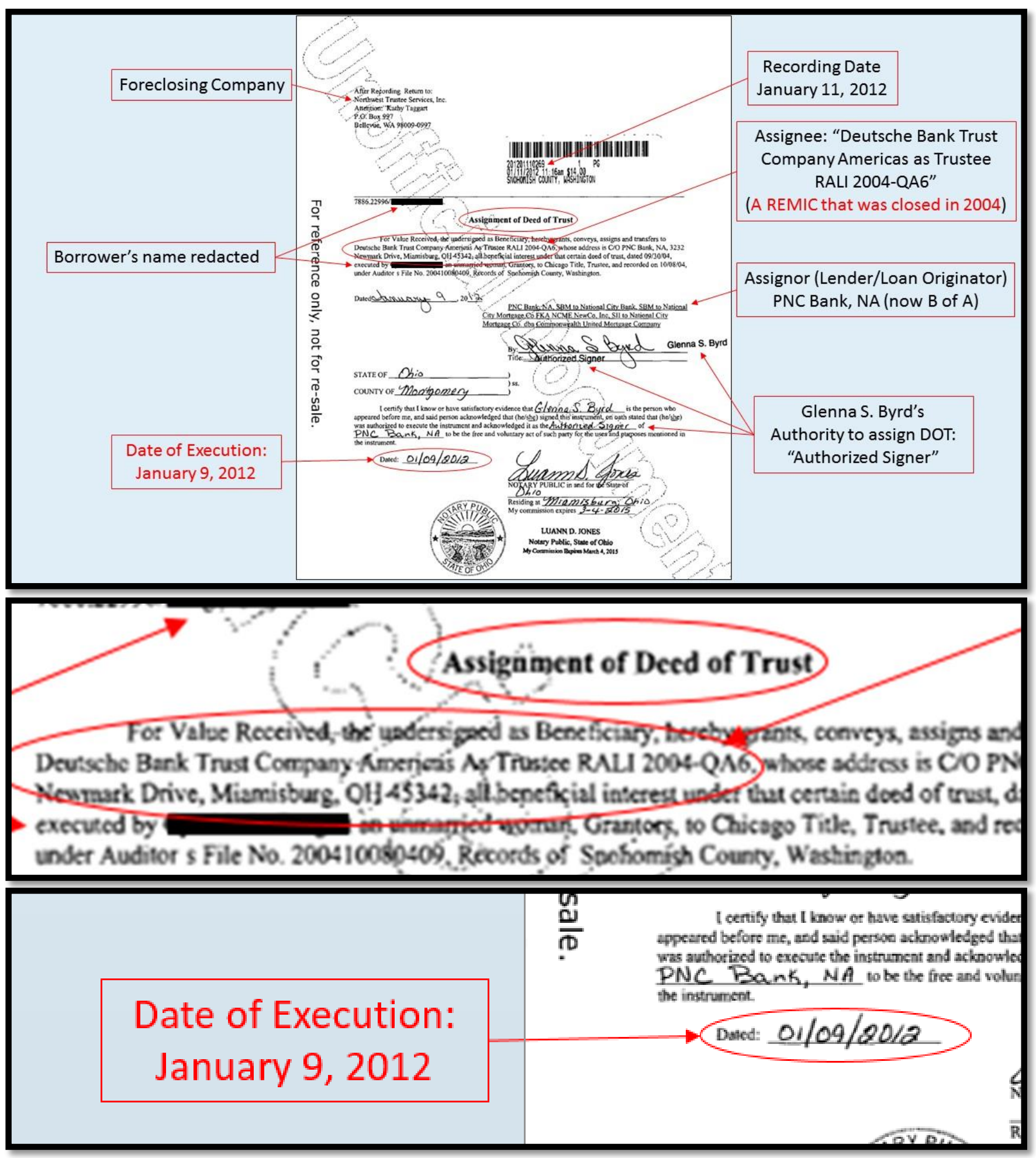

\subsubsection{Figure 5. Example of a Rogue Assignment}




\section{DISCUSSION}

The discussion in Section 3.5 regarding the Independent Foreclosure Review Program, together with the letter to Fed Chair Ben Bernanke (APPENDIX A), fairly indicate that federal government regulators have no will to criminally prosecute the Rogues for financial crimes against individual homeowners even though the crimes are being committed by nationally-chartered investment banks. And so individual homeowners are left to fend for themselves against these behemoths. As a result, a hodge-podge of civil cases in State courts have created such a plethora of conflicting decisions that, in the aggregate, only serve to obfuscate the overriding principle of standing.

\subsection{Results and Interpretation}

Twenty-one of the 151 samples (14.1\%) met all five criteria set forth in Section 4.2 (Also See: Supplement 1 - Research Data). Does $14.1 \%$ in 2012 pose a public policy problem? I argue that it does because if that figure were to be extrapolated nationally, it equates to 258,965 Rogue foreclosures $(14.1 \% \times 1,836,634)$ in 2012 alone. Figure 6. 


\section{Historical Foreclosure Activity}

- U.S. Properties with Foreclosure Filings

\section{눈 RealtyTrac}

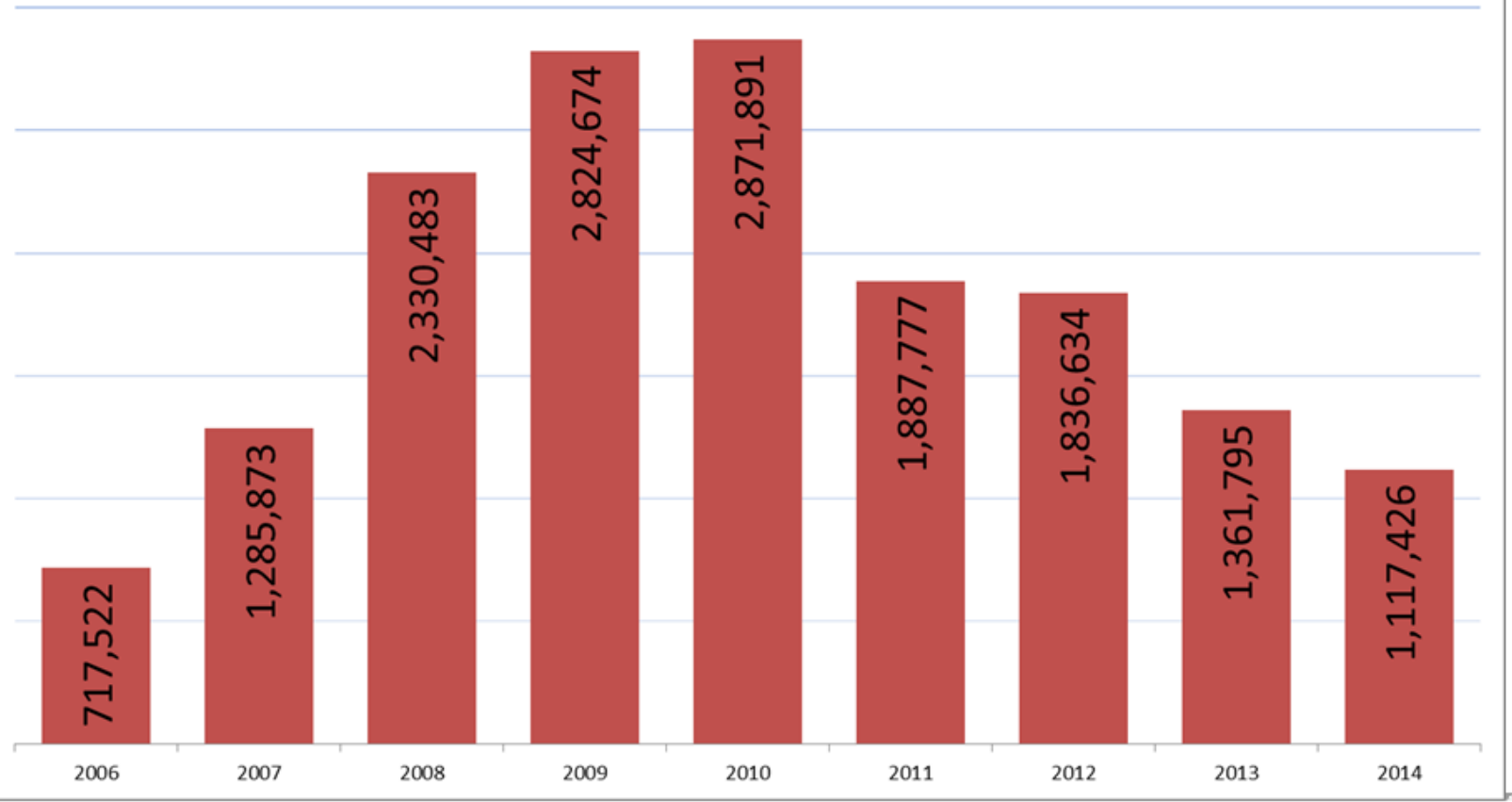

\subsubsection{Figure 6. Historical Foreclosure Activity Nationwide}

\subsubsection{Whack-A-Mole}

One of the chief foreclosure defense mistakes made by both pro se litigants and foreclosure defense attorneys alike is getting bogged down with playing a sort of legal whack-amole game instead of establishing lack of standing as the centerpiece of a foreclosure defense at the onset. After all, this game does resemble the typical defense against a foreclosing Rogue in a civil court. But the real competition is with the maker of the game, not an inanimate contraption that features pop-ups as rivals. Homeowners (and their attorneys, regrettably) have managed to get distracted by a game that they should not play. They spend an inordinate amount of time and energy concentrating on the misdeeds of the various Rogue affiliates when they should be 
focusing on the Rogue exclusively. A rogue and its affiliates are depicted in the right-hand portion of the Figure 7 diagram. Note that there is no connection between the borrower and the Rogue due to the fact that the assignment did not occur during the warehousing process.

Nevertheless, and for the purpose of explaining how easy it is to get caught up in the whack-amole game, it is instructive to discuss the various distractive roles played by these affiliates.

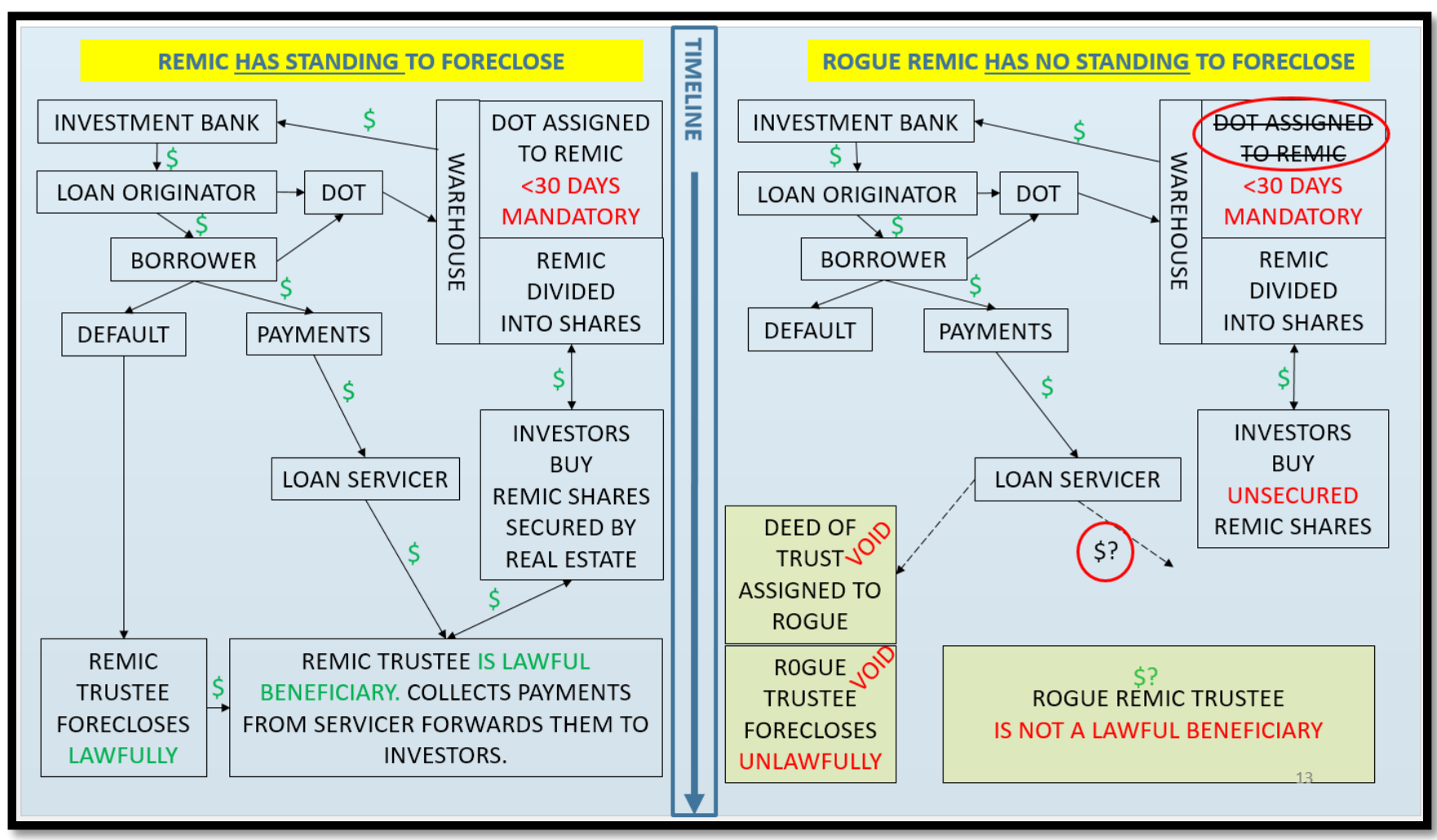

\subsubsection{Figure 7. Securitization Diagram}


REMIC:

REAL ESTATE MORTGAGE INVESTMENT CONDUIT An investment vehicle that holds mortgages in trust and issues securities representing an undivided interest in these mortgages.

\section{ROGUE REMIC:}

A REMIC in name only. A shell of financial instrument. It never had any mortgages assigned to it when it was created and, years later, is now closed to the introduction of new loans.

\section{AN EMPTY POOL}

\section{A POOL OF MORTGAGES}

\subsubsection{Figure 8. Distinguishing Between a Legitimate REMIC and a Rogue REMIC}

\subsubsection{The Beneficiary}

In Washington State, secured real estate obligations are usually not mortgages. Most are instead deeds of trust (DOTs). The lender is also the DOT beneficiary initially; but in the world of securitization and multiple DOT assignments, it is misnomer to refer to the subsequent owner of a loan to be a "lender"; so the term "beneficiary" is appropriately used to describe any and all subsequent assignees of a loan. When proper loan warehousing and securitization procedures were purposefully abused during the run-up to the financial crisis, such as the failure to assign certain loans to any REMIC during the warehouse phase, the loan beneficiaries in such instances became undiscernible. 


\subsubsection{MERS}

More often than not, MERS is named as the original beneficiary on a DOT. MERS is a proprietary, non-public record keeping system. Proprietary in this instance means that loan transfer information is shared among MERS member banks but not shared with the public. That includes information about warehouse transactions (or lack thereof) (See: "trade secrets" APPENDIX A p. 2, 5). MERS is never a lender initially (or ever) and a borrower never owes money to a record keeping system such as MERS regardless of whether MERS is named as the beneficiary of a DOT. Whether or not MERS appears as a beneficiary anywhere in a title chain, that does not relieve any REMIC trustee from the responsibility of accepting and recording an assignment of any mortgage (or deed of trust) at the time that the REMIC is created (and not years later).

"MERS is an acronym used for Mortgage Electronic Registration System, a system put into place by some of the largest U.S. banking institutions to avoid traditional state recordation systems" (Oppenheim, 2012, p. 761, FN 83). Oppenheim argues that the creation of MERS, a non-public recording system, did make the transfer of mortgages more efficient by circumventing county recording systems and fees. But it also gave rise to opportunities for unscrupulous loan warehousing practices. In some cases, warehouse operatives developed the practice of selling mortgages (or DOTs) to REMICs during the go-go years just prior to the crash; but never actually delivered the mortgages. Stated differently: although a Master Loan Schedule may have been created and represented to investors as the content of a given REMIC, and although that Schedule may have been a list of real loans, those loans could not become part of the REMIC unless the mortgage assignments to it were individually and contemporaneously executed and recorded in the county where each subject property is located. PSA rules (which mimic the requirements of tax and trust law) do not allow the private MERS record keeping system to substitute for a timely, local public notice of a mortgage transfer to a REMIC. This is 
common sense because a loan assigned to a REMIC is the "final stop" for a securitized loan. Either a REMIC becomes the beneficiary at the warehouse phase or it doesn't. If a loan cannot be transferred about after it has been securitized, MERS cannot lawfully come along years later and claim that it was the beneficiary all along and then execute an assignment to the trustee of an old, closed REMIC and then record it. That process violates trust law, IRS law and local law as it applies to slandering titles to real property (and common sense).

\subsubsection{The Loan Servicer}

In this age of loan securitization, the loan servicer -- the party to whom the borrower customarily makes payments -- is the only liaison between the borrower and the purported loan owner. When a belated assignment to a Rogue REMIC is executed and recorded (usually by a MERS representative) it is the loan servicer who facilitates that process. But if MERS is the assignor on a brand new assignment, the document itself is the proof that loan in question did not become a REMIC component during the warehouse phase which occurred years prior.

\subsubsection{The Successor Trustee / Debt Collector}

When a borrower executes a DOT in the state of Washington, the trustee named in the document is often a title insurance company, licensed attorney or some other reputable entity. Theoretically, the trustee or successor trustee is a neutral third-party who has a duty of good faith to both the borrower and the beneficiary. RCW 61.24.010(4). Once a Rogue becomes the DOT beneficiary of public record, which always occurs after a borrower falls behind in payments, a Rogue representative executes an APPOINTMENT OF SUCCESSOR TRUSTEE document facilitated, once again, by the loan servicer. The loan servicer generally executes such a document on behalf of the Rogue by power of attorney and, once again, the document is passed across the county auditor's desk by a loan servicer employee and into the public record without question. 
If a Rogue is involved, the successor trustee is neither neutral nor genuine. "(T)rustees who conduct foreclosures on a regular basis, are debt collectors under the Fair Debt Collection Practices Act" (Leen, 2014, p. $336 \mathrm{FN} 28$ ). And although loan servicers facilitate the execution and recording of bogus assignments and successor trustee documents, there is a rather large loophole in RCW 61.24.030 that insulates successor trustees from criminal complicity when they conduct foreclosures. The loophole is contained in RCW 61.24.030. Requisites to trustee's sale. (7)(a): "A declaration by the beneficiary made under the penalty of perjury stating that the beneficiary is the actual holder of the promissory note or other obligation secured by the deed of trust shall be sufficient proof as required under this subsection." In other words, the law was written with the presumption that in a non-judicial foreclosure, the purported beneficiary is above reproach if it asserts itself to be the true beneficiary; and the successor trustee/debt collector may accept that assertion without question. If the foreclosing entity is a major financial institution, as Rogue trustees always are, there is no downside to perjury and bogus recordings other than occasional monetary penalties. This is because none of the criminal laws are ever enforced against these banks or their principals (actual people) either nationally or locally.

\subsubsection{Which Mole to Whack?}

A typical foreclosure defense fails because the homeowner, whether pro se or represented by an attorney, chooses a complex whack-a-mole type of defense strategy in civil court rather than simply asserting that a void assignment to a Rogue equates to lack of standing by that Rogue. None of the Rogue affiliates have the perquisite legal standing to participate in a foreclosure because all of them derived their participation "rights" from a void assignment that was criminally recorded. So engaging in a legal battle with all of them at once (throwing shit against a wall to see what sticks) is waste of legal resources that confuses rather than clarifies. Moreover, if an assignment was executed and recorded criminally (RCW 9.38.020; RCW 40.16.030), then why must a victim of that crime be forced to 
confront alleged felons in a civil court in the first place? Crimes are matters for criminal courts. So the one mole to whack is the fake "beneficiary" that first shows up in the public record by way of criminally recording a bogus assignment; and thus creating the false illusion of legal standing. Those parties are the Rogue REMIC trustees or, more specifically, the parties that have overseen and benefitted from these Rogue activities since the foreclosure crisis began in 2007: the same TBTF institutions that were at the heart of the financial debacle.

\subsection{Criminality}

In the State of Washington, Rogue trustees commit crimes when they file bogus assignments for recording.

\subsubsection{RCW 9.38.020 False representation concerning title.}

Every person who shall maliciously or fraudulently execute or file for record any instrument, or put forward any claim, by which the right or title of another to any real or personal property is, or purports to be transferred, encumbered or clouded, shall be guilty of a gross misdemeanor.

AND

\subsubsection{RCW 40.16.030. Offering false instrument for filing or record:}

Every person who shall knowingly procure or offer any false or forged instrument to be filed, registered, or recorded in any public office, which instrument, if genuine, might be filed, registered or recorded in such office under any law of this state or of the United States, is guilty of a class $\mathrm{C}$ felony and shall be punished by imprisonment in a state correctional facility for not more than five years, or by a fine of not more than five thousand dollars, or by both.

\subsection{Law Enforcement Failures}

\subsubsection{Who Can We Shoot?}


While conducting this research, and trying to distinguish established criminal law from creative (but civil) legal arguments, I was often reminded of that famous passage in Chapter 5 of John Steinbeck's The Grapes of Wrath:

"But where does it stop? Who can we shoot? I don't aim to starve to death before I kill the man that's starving me."

"I don't know. Maybe there's nobody to shoot. Maybe the thing isn't men at all. Maybe like you said, the property's doing it. Anyway I told you my orders."

"I got to figure," the tenant said. "We all got to figure. There's some way to stop this. It's not like lightning or earthquakes. We've got a bad thing made by men, and by God that's something we can change."

In their 2010 book Winner Take All Politics, authors Jacob S. Hacker and Paul Pierson also made reference to this same "Who can we shoot" passage (p. 108) but they were unable to positively identify anyone in particular (nor did they even try). But these two authors were discussing a much larger socioeconomic issue which did not lend itself to identifying any individual guilty parties. However Rogue REMICs are bad things made by identifiable men. By the time I completed the research for this capstone, I was able to positively identify at least 5 of them who could have and perhaps should have been shot (figuratively speaking) in 2009. But the opportunity to do so was wasted by the hope and change president: Barack Obama.

The trustees of the 21 Rogue REMIC trustees identified in this research are all large, multinational banks. But there are not 21 different banks involved here. There are only seven. Five are U.S. based and two are based in foreign countries. On March 27, 2009, just two months after he took office, and in the abyss of the financial crisis, President Obama summoned a group of 13 men 
representing the largest U.S.-based financial institutions to the White House for a discussion about what must be done to deal with it. In presence were:

1. Ken Chenault, American Express

2. Ken Lewis, Bank of America (B of A)

3. Robert Kelly, Bank of New York (BONY)

4. Vikram Pandit, Citigroup (Citi)

5. John Koskinen, Freddie Mac

6. Lloyd Blankfein, Goldman Sachs

7. Jamie Dimon, JP Morgan Chase (Chase)

8. John Mack, Morgan Stanley

9. Rick Waddell, Northern Trust

10. James Rohr, PNC

11. Ronald Logue, State Street

12. Richard Davis, U.S. Bank

13. John Stumpf, Wells Fargo.

The domestic trustees of the five Rogue REMICs identified in my sampling are: B of A, BONY, Citi, Chase and U.S. Bank. And since Rogue foreclosures are still occurring in 2016, these five individuals could arguably be considered the heads crime syndicates: Lewis, Kelly, Pandit, Dimon and Davis. The heads of the two foreign banks identified in the sampling, HSBC and Deutsche Bank, were not in attendance at the 2009 meeting with Obama but they are no less culpable. There may be others, but that cannot be ascertained by this particular population sample of 151 foreclosure starts. More research would be necessary to make such a determination. 


\subsubsection{The First Line of Defense against Rogue REMICs: County Auditor}

Why do county recording officials literally assist in the perpetration of these felonies as a matter of routine? Why do they allow bogus assignments to be recorded? Considering the subject matter discussed in Section 5.4, it would be safe to say that County auditors nationwide are not oblivious to the issue. With that premise in mind, I contacted the local (Snohomish County) auditor and recommended that, as a matter of responsible public policy, she should direct her staff to be on the lookout for certain DOT assignments that conformed to the exact set of criteria depicted in Figure 5 and decline requests to record such assignments (APPENDIX B). I alleged to the Auditor that tendering such documents for recording was a violation of RCW 9.38.020 (a misdemeanor). I did not cite RCW 40.16.030, a felony (APPENDIX Y). The Auditor responded by notifying me that she would forward my concerns to the deputy prosecuting attorney. (APPENDIX C)

\subsubsection{The Second Line of Defense Against Rogue REMICs: County Prosecuting Attorney}

After writing to Snohomish County Prosecuting Attorney Dickerson (APPENDIX D), I received a response from Deputy Prosecuting Attorney Lindsay Downs. She referred to the County Auditor as her client which conversely meant that I would be an adversary going forward (APPENDIX E). Although I had hoped to convince the Deputy to at least launch a cursory investigation, she ultimately made it clear that there would be no investigation. She adopted the position that I misunderstood the lawful responsibilities of the County Auditor (APPENDIX E through H), citing EGGERT V. FORD, 21 Wn.2d 152 (Wash. 1944). Even though violations of RCW 9.38.020 and RCW 40.16.030 are misdemeanors and felonies respectively, the Deputy Prosecutor deemed my concerns to be civil matters (see: APPENDIX G, final paragraph). 


\subsubsection{The Third Line of Defense against Rogue REMICs: State Attorney General}

Upon realizing that neither the Snohomish County Deputy Prosecuting Attorney nor the Auditor were interested in confronting Rogue assignments as criminal acts, I brought my concerns to the attention of the State Attorney General (APPENDIX I). In that initial online message, I made reference to the McDonnell Analytics Report (See: Subsection 5.4.4) to the Seattle City Council (McDonnell, 2015). However, by the time I received a response from Assistant Attorney General Audrey Udashen (APPENDIX J), the Seattle City Council had already considered the McDonnell Report and summarily dismissed it. Included in Ms. Udashen's response to me is the following: “...we are not in a position to second guess the City Auditor or Attorney."

\subsection{Awareness of Local Recording Officials}

\subsubsection{Southern Essex County, Massachusetts}

Registers, registrars and recorders from across the country gathered in Atlantic City on Tuesday for the Annual Conference of The International Association of Clerks, Recorders, Election Officials and Treasurers (IACREOT). Several of those attending made the trip specifically to see Massachusetts Register John O'Brien's presentation on his findings of massive fraud he and Marie McDonnell of McDonnell Property Analytics, uncovered at the Massachusetts Southern Essex County Registry of Deeds... After the presentation O'Brien was inundated by nearly 150 recorders asking questions and wanting to conduct investigations of their own. (Zombeck, 2011)

\subsubsection{Guilford County, North Carolina}

Jeff Thigpen, the register of deeds for Guilford County, North Carolina is another early trail blazer in this effort. While he did not attend the conference, I spoke with him on Wednesday. "What [O'Brien] is pointing out in a fundamental way is that the assignments are fraudulent and people need to look at the findings. It goes to the heart of where we are in all this, Thigpen said, 
"These institutions were once transparent and trusted, we now have a system that stacks the deck in favor of the financial services industry. (Zombeck, 2011)

\subsubsection{San Francisco, California}

A report this week showing rampant foreclosure abuse in San Francisco reflects similar levels of lender fraud and faulty documentation across the United States, say experts and officials who have done studies in other parts of the country. The audit of almost 400 foreclosures in San Francisco found that 84 percent of them appeared to be illegal, according to the study released by the California city on Wednesday. (Reid, 2012)

\subsubsection{Seattle, Washington}

Succumbing to public pressure in 2014 , the City of Seattle commissioned a study of purportedly wrongful foreclosures. They hired McDonnell Property Analytics, the same company hired by John O’Brien 5 years prior. They got a report that was similar to the findings in other jurisdictions.

Not only is MERS corrupting the land records; it is interfering with the public's access to justice by infecting the Washington state and federal courts with phony title documents that purport to give its members legal standing when, in actuality, they have none. (McDonnell. 2015. p. 46) After receiving the report in September, 2015, the Seattle City Council decided that, instead of interpreting the McDonnell report as a wake-up call, it was criticized by the City Auditor and dismissed for its "lack of objectivity" (McDonnell. 2015. p. 3). Marie McDonnell apparently made the same miscalculation in her report to the Seattle City Council that so many homeowners have made when tangling with Rogues: the introduction of so much information about the banks' securitization and loan transfer misdeeds that the overarching issue of Rogue REMIC standing got lost in the message: 
Our examination began with a review of 195 Assignments Deed of Trust/Mortgage filed with the King County Recorder's Office on or between January 1, 2013 and June 30, 2013. ... How discoverable is the true, current owner of a mortgage? Without exception, in 195 instances $100 \%$ of the time across the board - we found that we could not determine who the true, current owner of the mortgage was... (McDonnell, 2015, p. 41-42)

It is true that all manner of flawed (and thus "voidable") mortgage documents were recorded before, during and after the financial crisis, But in her zeal to expose the magnitude of the Big Banks' misdeeds to (what she thought was) a receptive Seattle City Council, Marie McDonnell got caught up in a classic whack-a-mole game. In response, the City Council found itself hamstrung by the "who can we shoot" syndrome. They were faced with the untenable choice between shooting everybody and shooting nobody. They chose the latter. The Legal Analysis by Seattle City Auditor David G. Jones included the following: "The City Attorney stated that many of the consultant's legal conclusions and opinions can only be determined by statute or a court of law, and some may be an incorrect interpretation of State law. The City Attorney's Office recommended that we not endorse the report” (McDonnell. 2015. p. 3). (emphasis in original)

Ms. Udashen chose not to second-guess the City Auditor or Attorney. However she did invite me to furnish her with examples of fraudulent assignments, which I did on October 26, 2015: all 21 of them. (APPENDIX K). I did get a response on November 9, 2015 which epitomized the collective indifference of state and local officials toward the white collar crime of foreclosure fraud. Collectively, they have no interest in trying to even understand the problem of fraudulent Rogue assignments, let alone confront it. (APPENDIX L through Q) 


\subsection{Poison in the Financial Bloodstream}

In 2010, Ray Brescia J.D. Yale Law School, observed that defective financial products, such as Rogue REMICs adversely affected the health and wellbeing of homeowners comparable to other consumer products which are later deemed to be dangerous to the general public. "A poison has entered the financial bloodstream. We have responded by seeking to prop up the purveyors of the poison so that they do not lose their investment in it. We have allowed those who sold the poisonous product to walk away from the fallout, after reaping large profits for years" (Brescia, 2010 p. 1). Two years after Brescia's assessment, when robust regulatory enforcement failed to materialize, Borden and Reiss (2013) literally implored lawyers and academics alike to stand up to the opposing and formidable political winds of regulatory capture: “... as wielders of the pen, we can attempt to influence policy and industry practices that we believe to be harmful to a well-ordered real estate market” (p. 9).

\subsubsection{Abdication of Responsibility by Public Officials}

The two criminal statutes which are applicable to the recording of bogus assignments are only worthwhile if they are enforced. Private Citizens do not personally have the authority to enforce these laws. All they can do is bring the offenses to the attention of public officials, together with sufficient evidence that crimes have been committed (or that crimes are ongoing) and request an investigation. There are statutes applicable to public officials who refuse to investigate a well-documented citizen complaint of ongoing crimes.

\subsubsection{RCW 9A.08.010 General requirements of culpability.}

(1) Kinds of Culpability Defined.

(b) KNOWLEDGE. A person knows or acts knowingly or with knowledge when: 
(i) he or she is aware of a fact, facts, or circumstances or result described by a statute defining an offense; or

(ii) he or she has information which would lead a reasonable person in the same situation to believe that facts exist which facts are described by a statute defining an offense

\subsubsection{RCW 9A.80.010 Official misconduct.}

(1) A public servant is guilty of official misconduct if, with intent to obtain a benefit or to deprive another person of a lawful right or privilege:

(a) He or she intentionally commits an unauthorized act under color of law; or

(b) He or she intentionally refrains from performing a duty imposed upon him or her by law.

(2) Official misconduct is a gross misdemeanor.

\subsubsection{RCW 42.20.100 Failure of Duty by Public Officer a Misdemeanor.}

Whenever any duty is enjoined by law upon any public officer or other person holding any public trust or employment, their wilful neglect to perform such duty, except where otherwise specially provided for, shall be a misdemeanor.

\subsection{Foreclosures and Suicides}

The extensive discussion of legal standing was necessary in order to draw a clear distinction between a lawful foreclosure and an unlawful Rogue foreclosure. The fact is, most foreclosures are not unlawful even though the affected homeowner may have been duped and/or deceived into accepting a loan from an assortment of unscrupulous parties; and then foreclosed upon by another group of unethical people. And so if a lawful foreclosure results in a homeowner suicide, trying to blame the death on any of these parties would be a dubious legal endeavor. However if a correlation can be established between 
suicides and blatantly unlawful foreclosures, there may be a compelling legal argument that Rogue foreclosures directly cause or contribute to suicides.

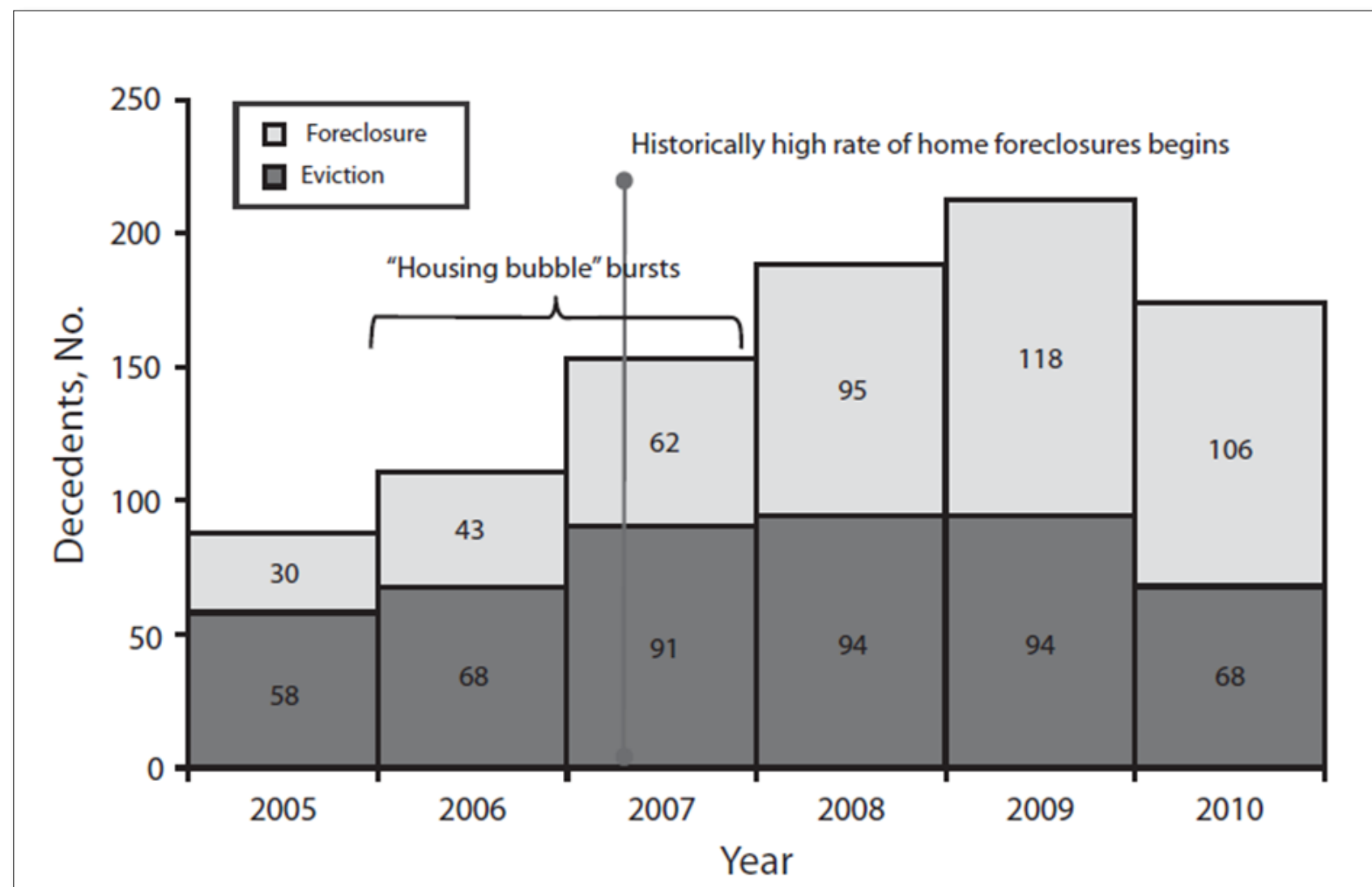

Note. The sample size was $n=929$. There was a significant increase in eviction- 0 r foreclosure-related suicides from 2006 to $2007\left(\chi^{2}=6.68 ; P=.01\right)$, and from 2007 to $2008\left(\chi^{2}=3.79 ; P=.05\right)$.

Source. Information about timing of the US housing crisis comes from The Economist. ${ }^{10}$

FIGURE 1-Frequency of suicides associated with eviction or foreclosure in context of the US housing crisis: National Violent Death Reporting System, United States, 2005-2010.

\subsubsection{Figure 8. Frequency of Suicides Associated With Eviction or Foreclosure}

A 2013 article by Katherine Fowler et al. was published in The American Journal of Public Health that quantified a general correlation between suicides and foreclosures in 16 states between 2005 and 2010. Washington State was not one of them. "This study was the first to our knowledge to systematically examine suicides linked with eviction and foreclosure. A review of suicide deaths in 16 


\section{James Campbell | Master of Arts in Policy Studies \\ University of Washington Bothell | June 6, 2016 \\ An Inquiry into the Legal Standing of Rogue REMICs in Foreclosures}

States found more than 900 eviction- or foreclosure-related suicides between 2005 and 2010" (Fowler et

al., 2013). Although the data gathered is not nationwide in scope, it is nonetheless instructive for modeling and quantifying a correlation between homeowner suicides and Rogue foreclosures in particular. Figure 8. Phyllis Walsh, a Seattle homeowner who is now deceased, was the victim of a Rogue foreclosure. Figures $9,10 \& 11$. 


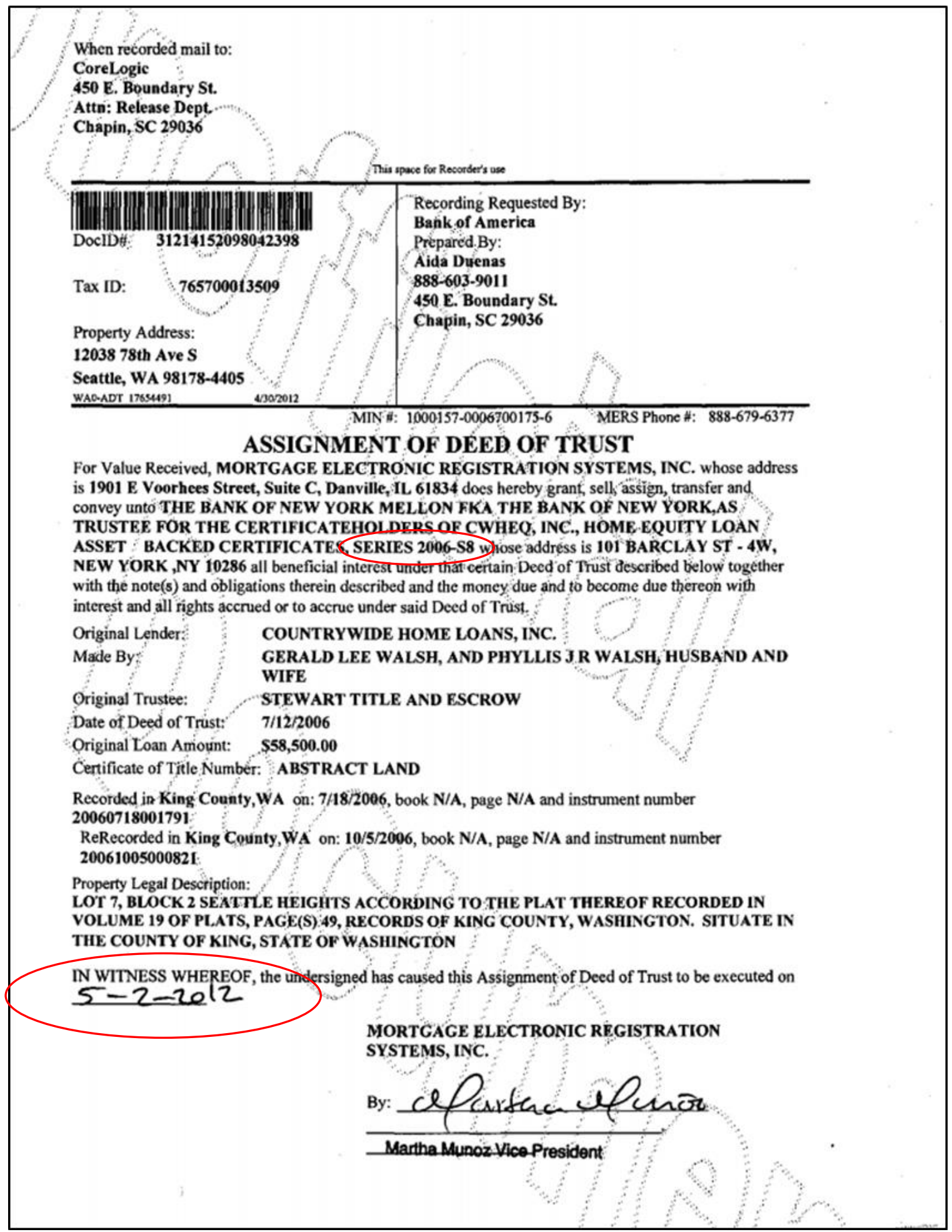

5.6.3 Figure 9. Assignment from MERS to Bank of New York Mellon (Phyllis Walsh) Source: Public Records of King County, WA http://146.129.54.93:8193/search.asp?cabinet=opr Instrument No. 31214152098042398 


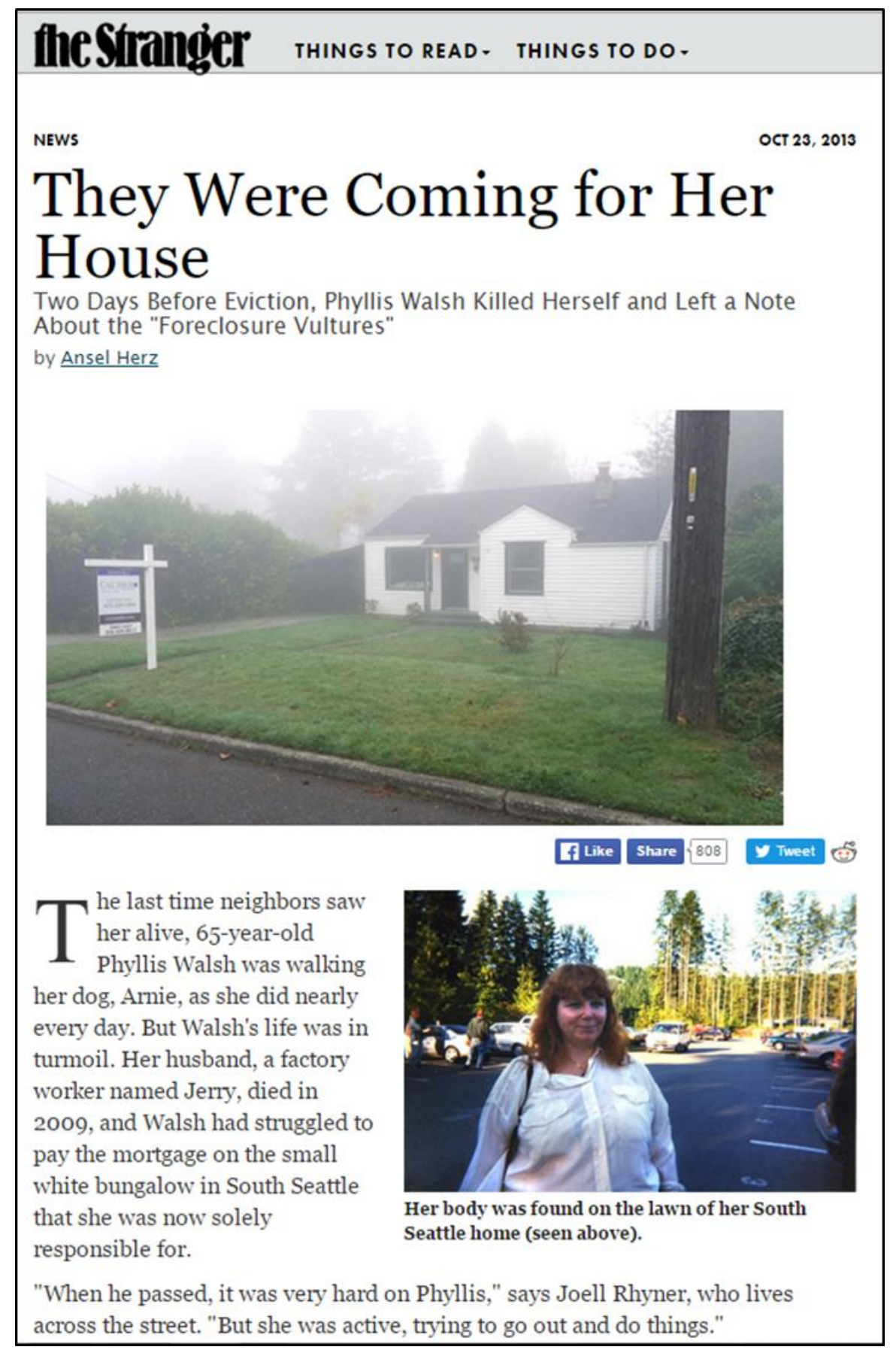

\subsubsection{Figure 10. The Death of Phyllis Walsh (Herz, 2013)}


About the stuff

The foreclosure people will be here on thurs. they may or may not be reasonable. So, any trinkets, mementos, art Whatever should be removed quickly. Any thing too large, heavy, cumbersome or difficult let the foreclosure vultures handle...

Except for a hard decision, the last couple weeks have been filled with wonderful days, each of them perfect. Family, Church, friends, music, Arnie, enjoying the back yard...

Everything is in a terrible muddle, the house got foreclosed

While I was in the middle of a refinance (!) jeez

Jerry's been gone four long years and I'm not

Doing so well. This is too hard to do alone.

\subsubsection{Figure 11. Text of Phyllis Walsh Suicide Note (Herz, 2013)}

\section{CONCLUSIONS}

A common refrain since the housing bubble burst in 2008 is that millions of homeowners were foolhardy in their mortgage borrowing. Thus they got what they deserved - foreclosure - when they could no longer make their payments. And why should these people be allowed to live in their home for free while the banks resolve their paperwork snafus? Worse still, some of these homeowners are attempting to have their mortgage debt cancelled altogether as if they're owed a free house!

Missing from the foregoing discussion is that these same homeowners were unwitting participants in an elaborate pump and dump scheme to deceive and profit from unwitting REMIC investors. By failing to record assignments during the warehouse phase of REMIC creation, the big investment banks created REMICs that existed in name only; then sold shares of them to the public as if they were the real thing. There's a common term for that sort of activity whether it is conducted by an individual person or a multinational financial institution. There is an abundance of empirical evidence suggesting that between 2003 and 2007, some private label REMICs were nothing more than Ponzi schemes. The proof of this is the non-existence of contemporaneously recorded assignments. If 
mortgages truly did become REMIC components during that timeframe, there would be no need to execute and record bogus mortgage assignments in the present day.

The proposition of inserting any given mortgage into a REMIC that has been closed for years is comparable to boarding a passenger onto an airliner that is already in mid-flight to its destination. The difference between these two propositions is that one is preposterous while the other is a felony in the State of Washington. Proof of these felonies by some of the nation's largest financial institutions lies in the public records pertaining to a particular 54 square mile segment of Snohomish County, Washington. In that segment, $14.1 \%$ of all foreclosures in 2012 were started with the executions and recordings of ASSIGNMENT OF DEED OF TRUST documents to closed REMICs.

This Inquiry has determined that local officials, including the County Auditor, County Prosecutor and State Attorney General, have all declined to participate in an investigation of twenty one felony violations of RCW 40.16.030 in Snohomish County. They are therefore acquiescing to ongoing (perhaps daily) crimes against land titles at the Snohomish County Auditor's Office. This inaction is consistent with the same lack of enforcement at the national level.

The failure of the Independent Foreclosure Review Program and the near-universal election by federal regulators to extract multibillion dollar settlements and/or fines from the large, multinational banks, with no criminal prosecutions, only serves to discourage law enforcement locally. In fact as late as April, 2016, Goldman Sachs entered into a \$5.06 billion settlement agreement with the U.S. Government for misleading mortgage bond investors during the financial crisis. Like the similar multibillion settlements that preceded it, the settlement did not include any criminal charges (Merle, 2011). If the federal government has concluded that these too big to fail multinationals are also too big to prosecute, then it is unsurprising that county prosecutors would be reluctant to take up such battles in local courts. Moreover, the breadth of the Rogue REMIC problem is widely misunderstood and 
therefore not addressed in any meaningful way by local authorities. But for the lack of understanding combined with the lack of political will to enforce existing law, the crimes go on. Seattle's total rejection of the McDonnell Report is evidence of this.

The data suggest that Rogue REMIC trustees have been partially appeasing REMIC investors over the past decade by systematically creating false legal standing, foreclosing on homes, corrupting land titles in the process, then passing these titles on to the future buyers of these homes. They liquidate foreclosed properties rather than issuing refunds to investors out of their own ill-gotten gains and/or clawing back the billions in bonuses paid to the individual bank employees who personally approved the sale of these Rogue REMIC shares to the public.

As of the completion date of this Inquiry, the social and economic fallout from foreclosures has been ongoing for nearly a decade now. It is disturbing to consider how many of them may have been conducted by Rogues. The data suggest that the 21 Rogue REMICs that I gleaned out of 151 local samples is indicative of a nationwide phenomenon. So what can be done with this information?

\subsection{The Way Forward}

I demonstrated in Section 5.1 why there is no relationship between any Rogue REMIC and any homeowner until such time that an assignment is recorded. That never happens until after a homeowner goes into payment arrears. The Rogue trustee then issues a written Notice of Default to the homeowner: the first step in a foreclosure. Recording a Rogue assignment is a criminal act because it is a void document. This Inquiry demonstrates that the Attorney General is reluctant to whole-heartedly accept that premise. The Snohomish County Prosecutor declined to investigate Rogue REMIC assignments as criminal acts.

Considering the foregoing circumstances, what would be the appropriate course of action for a homeowner if a Rogue sends a Notice of Default? First, a civil Complaint would need to be filed in 
Superior Court by the homeowner/plaintiff asserting that the assignment to the Rogue was a criminal violation of RCW 40.16.030 Offering false instrument for filing or record; and must therefore be expunged from the public record as a matter of law. The Complaint should also assert that the matter is criminal in nature as well as civil. There is enough information contained in this Inquiry to compose a convincing argument as to why such an assignment is both void and criminal. This complaint should be filed before a NOTICE OF TRUSTEE'S SALE is recorded to put the Rogue on notice that subsequent clouds on the property title are separate violations of RCW 40.16.030. Such a complaint would make no reference to the Notice of Default because it was issued by a party with no standing to foreclose in the first place. It too is a void document. The Rogue trustee would then need to respond to the complaint with an explanation of why the assignment is neither void nor criminal. That would be an interesting read.

The foregoing hypothetical case may never be litigated; and to my knowledge, there are no precedents for this kind of litigation. Nevertheless, if just one homeowner were to prevail in a civil lawsuit of this sort, it just might turn the tide against the Rogues. Even if it doesn't, if this Inquiry helps just one homeowner to prevail against just one Rogue, then it was worth the effort. 


\section{REFERENCES}

Allen, Linda. (2011, August 1). Shaky Claims Tougher to Track as Time Goes By. American Banker. Retrieved from: http://www.americanbanker.com/magazine/121_8/shaky-claims-tougher-totrack-as-time-goes-by-1040323-1.html

["Robo-signing" of mortgages still a problem]. (2011, July 18). Retrieved from: http://www.cbsnews.com/news/robo-signing-of-mortgages-still-a-problem/

Borden, B. \& Reiss, D. (2012). Once a Failed Remic, Never a Remic. Brooklyn Law School Legal Studies Research Papers, Accepted Paper Series Research Paper No. 317. Retrieved from: http://papers.ssrn.com/sol3/papers.cfm?abstract_id=2185420

Borden, B. \& Reiss, D. (2013-1). Dirt Lawyers and Dirty Remics. Brooklyn Law School Legal Studies Research Papers Accepted Paper Series Research Paper No. 322. Retrieved from: http://papers.ssrn.com/sol3/papers.cfm?abstract_id=2209863

Borden, B. \& Reiss, D. (2013-2). Dirt Lawyers and Dirty Remics: A Debate. Probate \& Property, Volume 27, No 3 (C) 2013 Brooklyn Law School, Legal Studies Paper No. 361. Retrieved from: http://brooklynworks.brooklaw.edu/cgi/viewcontent.cgi?article=1014\&context=faculty

Brescia, R. (2009-2010). [Tainted Loans: The Value of Mass Torts Approach in Subprime Mortgage Litigation]. University of Cincinnati Law Review 78(1), 1-80. Retrieved from: http://papers.ssrn.com/sol3/papers.cfm?abstract_id=1420792 
Carpenter, D. \& Murphy, M. (2010). The "Volcker Rule": Proposals to Limit "Speculative" Proprietary Trading by Banks. Congressional Research Service. Retrieved from: http://www.fas.org/sgp/crs/misc/R41298.pdf

Carcano, Robert, Senior Counsel. (2014). ABCs of Legal Analysis of RMBS Securitizations. NAIC (National Association of Insurance Commissioners). Retrieved from: http://www.naic.org/structured_securities/documents/ABCs_of_Legal_Analysis_of_RMBS_Sec $\underline{\text { uritizations.pdf }}$

[Credit Default Swap - CDS] Retrieved from: http://www.investopedia.com/terms/c/creditdefaultswap.asp

Deed of Trust. (n.d.). Retrieved from: http://legal-dictionary.thefreedictionary.com/Deed+of+Trust

Drew, T. (1993). [Civil Procedure Association Must Allege Specific Injury to Meet Standing Requirement of Article III]. Suffolk University Law Review 27(3), 1048-1053.

Fabozzi, F., \& Modigliani, Franco. (1992). Mortgage and mortgage-backed securities markets. (Harvard Business School Press series in financial services management). Boston, Mass.: Harvard Business School Press. 
Fowler, Katherine A., Gladden, Matthew, Vagi, Kevin J., Barnes, Jamar, \& Frazier, Leroy. (2015). Increase in suicides associated with home eviction and foreclosure during the US housing crisis: Findings from 16 national violent death reporting system states, 2005-2010. The American Journal of Public Health, 105(2), 311.

Froehle, T. (2011). Standing in the Wake of the Foreclosure Crisis: Why Procedural Requirements are Necessary to Prevent Further Loss to Homeowners. Iowa Law Review 96(5), 1719-1744.

Herz, Ansel. (2013, October 13). They Were Coming For Her House. The Stranger. Retrieved from: http://www.thestranger.com/seattle/the-bank-was-coming/Content?oid=18019670

[History of the Government Sponsored Enterprises]. (n.d.). Federal Housing Finance Agency Office of the Inspector General. Retrieved from: http://fhfaoig.gov/LearnMore/History\#Anchor48

Horton, B. (2009). In Defense of Private-Label Mortgage-Backed Securities. Florida Law Review 61(4), 827-882.

[Interagency Review of Foreclosure Policies and Practices]. (2011, April). Federal Reserve System; Office of the Comptroller of the Currency; Office of Thrift Supervision. Retrieved from: http://www.occ.gov/news-issuances/news-releases/2011/nr-occ-2011-47a.pdf 
Katz, A. (2009). Our Lot: How Real Estate Came to Own Us. New York, NY: Bloomsbury

Leen, D. (2013-2014). Wrongful Foreclosures in Washington. Gonzaga Law Review 49(2), 331-382.

Levitin, A. (2010). Robo-Signing, Chain of Title, Loss Mitigation, and Other Issues in Mortgage Servicing: Hearing Before the Subcomm. on Hous. and Cmty. Opportunity of the H. Fin. Serv. Comm., 111th Cong., Nov. 18, 2010 (Statement of Associate Professor Adam J. Levitin, Geo. U. L. Center). Retrieved from: $\underline{\text { http://scholarship.law.georgetown.edu/cgi/viewcontent.cgi?article=1110\&context=cong }}$

Levitin, A. \& Rahn-Twomey, T. (2011-1). Mortgage Servicing. Yale Journal on Regulation, 28, 1-471.

Levitin, A. \& Rahn-Twomey, T. (2011-2). Mortgage Servicing, Georgetown Public Law and Legal Theory Research Paper No. 11-09. Georgetown Business, Economics and Regulatory Law Research Paper No. 11-01. Georgetown Law. The Scholarly Commons. Retrieved from: https://www.law.georgetown.edu/cle/materials/alumni/mortgage-servicing.pdf

Levitin, A. (2013-2014). Paper Chase: Securitization, Foreclosure, and the Uncertainty of Mortgage Title, The. Duke Law Journal 63(3), 637-734

Loftsgordon, A. (n.d.). What is a pooling and servicing agreement (PSA) in the mortgage industry? Nolo.com. Retrieved from: http://www.nolo.com/legal-encyclopedia/what-pooling-servicingagreement-psa-the-mortgage-industry.html 
McDonnell, M. (2015, September). [Forensic Examination of Real Property Records Commissioned by the Seattle City Council]. Retrieved from:

http://www.seattle.gov/Documents/Departments/CityAuditor/auditreports/MortgageDocReview MemoAndFinalReport.pdf

McLean, B. \& Nocera, J. (2010). All The Devils Are Here. Penguin Books Ltd. London, England.

Merle, Renae. (2011, April 11). Goldman Sachs Pays \$5 Billion to Settle Allegations it Sold Shoddy Mortgages. Washington Post. Retrieved from: https://www.washingtonpost.com/news/business/wp/2016/04/11/goldman-sachs-pays-5-billionto-settle-allegations-it-sold-shoddy-mortgages-prior-to-financial-crisis/

Oppenheim, R. \& Trask-Rahn, J. (2012). Deconstructing the Black Magic of Securitized Trusts: How the Mortgage-Backed Securitization Process Is Hurting the Banking Industry's Ability to Foreclose and Proving the Best Offense for Foreclosure Defense. Stetson Law Review 41(3), 745-778.

[Politics of Foreclosure, The.] (2010, October 9). Washington's latest obstacle to a housing market recovery. Wall Street Journal, Eastern edition. Retrieved from: http://www.wsj.com/articles/SB10001424052748704696304575538440995389092 
Rehrauer, M. (2010). Regaining the Wonderful Life of Homeownership Post-Foreclosure Defending Homeowners from Eviction after Foreclosure by Attacking the Ownership Rights of the Foreclosing Entity. Northeastern University Law Journal 2(1), 5-40.

Reid, Tim. (2012, February). Foreclosure abuse rampant across U.S., experts say. Reuters. Retrieved from: http://www.reuters.com/article/usa-housing-defaults-idUSL2E8DGDPY20120217

Streissguth, Tom. (n.d.). What is an Assignment of Trust Deed? Retrieved from: $\underline{\text { http://info.legalzoom.com/assignment-trust-deed-20546.html }}$

Warehouse Lending (n.d.). Investopedia.com. Retrieved from: http://www.investopedia.com/terms/w/warehouse_lending.asp

What You Need to Know: Independent Foreclosure Review. (n.d.). Board of Governors of the Federal Reserve System. Retrieved from: http://www.federalreserve.gov/consumerinfo/independentforeclosure-review-payment-agreement.htm

Zacks, E. \& Zacks, D. (2014-2015). Standing Question: Mortgages, Assignment, and Foreclosure, A. Journal of Corporation Law 40(3), 705-738.

Zombeck, R. (2011, July 5), Mass Register John O'Brien's Presentation Draws Crowd of Recorders in Atlantic City. Huffpost Business. Retrieved from: http://www.huffingtonpost.com/richardzombeck/mass-register-john-obrien_b_888839.html 


\title{
APPENDIX A 04.10.2013 Letter to Ben Bernanke
}

April 10, 2013

\author{
The Honorable Ben Bernanke Chairman \\ Board of Governors of the Federal Reserve System \\ 20th Street and Constitution Avenue NW \\ Washington, DC 20551 \\ The Honorable Thomas Curry \\ Comptroller of the Currency Administrator of National Banks \\ Washington, DC 20219 \\ Dear Chairman Bernanke and Comptroller Curry:
}

We are writing to urge you to reconsider the position relayed by your staff at a meeting yesterday that you will not provide any documents in response to our January 31, 2013, request as Members of Congress relating to systemic and widespread violations of law committed by mortgage servicing companies.

Two years ago this week, your offices issued a public report announcing that you determined that 14 mortgage servicing companies were engaging in "violations of applicable federal and state law." You found that these abuses have "widespread consequences for the national housing market and borrowers." You also explicitly referenced instances of abuse, including illegal foreclosures against our nation's men and women in uniform who are protected by the Servicemembers Civil Relief Act (SCRA).

Based on these findings, you issued consent orders requiring these mortgage servicers to retain independent consulting firms to conduct a thorough review of their foreclosure actions in 2009 and 2010. Before this Independent Foreclosure Review (IFR) process was completed, however, and before a single borrower had received remediation, you finalized settlement agreements in February 2013 terminating the review process with 11 of these servicers.

We have requested information about the process used to conduct this review and the extent to which violations of law were found. We made 14 specific requests in our letter to you in January, and to date you have provided only one full response, three partial or minimal responses, and no responses to nine of the requests (see Appendix A). You have provided little specific information on what the review actually found, such as the number of improper foreclosures, the amount and number of instances of inflated fees, or the extent of abusive practices by each mortgage servicer. 
The Honorable Ben Bernanke

The Honorable Thomas Curry

Page 2

You have, however, provided several salient facts: (1) mortgage servicing companies spent approximately $\$ 2$ billion on this review; (2) although more than 800,000 loan fdes were identified for review, only about 114,000 were reviewed by independent consultants by the end of 2012; and (3) remediation will be paid to injured borrowers starting at the end of this week, though the remedial compensation is not based directly on findings from the review.

At the meeting yesterday, Federal Reserve staff argued that the documents relating to widespread legal violations are the "trade secrets" of mortgage servicing companies. In addition, staff from the Office of the Comptroller of the Currency (OCC) argued that these documents should be withheld from Members of Congress because producing them could be interpreted as a waiver of their authority to prevent disclosure to the public of confidential supervisory bank examination information.

We strongly believe that documents should not be withheld from any Member of Congress based on the flawed argument that illegal activity by banks is somehow their proprietary business information. Breaking the law is not a corporate trade secret. As regulators, you identified systemic and widespread abuses two years ago, and concealing important information about these violations limits our ability to fulfill our responsibility to conduct oversight over the actions of mortgage servicing companies and to develop legislation to protect our constituents from further abuse.

The position conveyed by your staff is even more troubling given that the abuses you identified are apparently more widespread than previously known. For example, one press account recently reported that the review found that "the nation's biggest banks wrongfully foreclosed on more than 700 military members during the housing crisis." 1 On Tuesday, however, your staff informed us that more than 1,000 servicemembers will receive compensation under the settlement for actual or potential SCRA violations involving illegal foreclosures. Despite these violations, your staff refused repeatedly to identify the number of servicemembers illegally foreclosed on by each mortgage servicer. In fact, your staff refused to identify information about any illegal activities by any specific mortgage servicer.

Your staff also stated that the performance of one of the independent consultants conducting foreclosure reviews was so poor that you issued a letter faulting the company and directing it to cure its deficiencies. Your staff would not elaborate, however, and they declined to identify the independent consultant or the mortgage servicing company involved.

Last week, the Government Accountability Office (GAO) issued a report finding that the "[c]omplexity of the reviews, overly broad guidance, and limited monitoring for consistency impeded the ability of the Office of the Comptroller of the Currency (OCC) and the Board of

${ }^{1}$ Banks Find More Wrongful Foreclosures Among Military Members, New York Times (Mar. 3, 2013) (online at http://dealbook.nytimes.com/2013/03/03/banks-find-more-wrongful-foreclosures-among-military-members/). 
The Honorable Thomas Curry

The Honorable Ben Bernanke

Page 3

Governors of the Federal Reserve System (Federal Reserve) to achieve the goals of the foreclosure review." The report concluded that "limited communication with borrowers and the public adversely impacted transparency and public confidence."2

Although we do not know the extent to which you were involved in your staff's preparation for yesterday's meeting, it is our sincere hope that we can work toward an accommodation that is mutually acceptable and serves the interests of both your offices and Members of Congress. The remainder of this letter provides additional background on our requests.

\section{Findings of Violations of Federal and State Law}

Two years ago, your offices concluded that mortgage servicing companies engaged in widespread and systemic violations of federal law. In April 2011, your offices joined the then-Office of Thrift Supervision in issuing a joint report summarizing the results of "horizontal reviews" you conducted of the nation's 14 largest mortgage servicers. The summary stated:

The reviews found critical weaknesses in servicers' foreclosure governance practices, foreclosure document preparation processes, and oversight and monitoring of third-party vendors, including foreclosure attorneys. ... [T] he weaknesses at each servicer, individually or collectively, resulted in unsafe and unsound practices and violations of applicable federal and state law and requirements. ${ }^{3}$

The summary also described the widespread nature of these legal violations:

The results elevated the agencies' concern that widespread risks may be presented - to consumers, communities, various market participants and the overall mortgage market. The servicers included in this review represent more than two-thirds of the servicing market. Thus, the agencies consider problems cited within this report to have widespread consequences for the national housing market and borrowers. ${ }^{4}$

\footnotetext{
${ }^{2}$ Government Accountability Office, Foreclosure Review: Lessons Learned Could Enhance Continuing Reviews and Activities Under Amended Consent Orders (GAO-13-277) (Apr. 4, 2013) (online at www.gao.gov/products/GAO-13-277).

${ }^{3}$ Federal Reserve System, Office of the Comptroller of the Currency, and Office of Thrift Supervision, Interagency Review of Foreclosure Policies and Practices (Apr. 13, 2011) (online at www.occ.treas.gov/news-issuances/newsreleases/201 1/nr-occ-201 1-47a.pdf) (emphasis added).

${ }^{4} I d$. (emphasis added).
} 
The Honorable Ben Bernanke

The Honorable Thomas Curry

Page 4

In addition, although your staff seemed unaware of it during our meeting yesterday, your 2011 report also identified specific cases of improper foreclosures that violated the SCRA, a federal law with criminal sanctions passed by Congress to provide additional foreclosure protections for members of our military:

[E]xaminers did note cases in which foreclosures should not have proceeded due to an intervening event or condition, such as the borrower (a) was covered by the Servicemembers Civil Relief Act, (b) filed for bankruptcy shortly before the foreclosure action, or (c) qualified for or was paying in accordance with a trial modification. $^{5}$

You also concluded that mortgage servicing companies filed false documents with courts. For example, you found that Bank of America, N.A.:

filed or caused to be filed in state and federal courts affidavits executed by its employees or employees of thirdparty service providers making various assertions, such as ownership of the mortgage note and mortgage, the amount of the principal and interest due, and the fees and expenses chargeable to the borrower, in which the affiant represented that the assertions in the affidavit were made based on personal knowledge or based on a review by the affiant of the relevant books and records, when, in many cases, they were not based on such personal knowledge or review of the relevant books and records; ... [and] failed to sufficiently oversee outside counsel and other third-party providers handling foreclosure-related services. ${ }^{6}$

To address these widespread and systemic violations of law, you entered into consent orders requiring mortgage servicing companies to retain independent firms to conduct a thorough review of foreclosure actions that were pending from January 1, 2009, through December 31, 2010, to identify as many borrowers as possible who were financially harmed by the banks' deficient practices. You also directed the mortgage servicers to submit for your approval "engagement letters" establishing the terms of the reviews to be conducted by the independent firms, including the specific review methodologies to be employed. ${ }^{7}$

On January 7, 2013, your offices announced that you were suddenly terminating the independent review process for many of the servicers subject to the April 2011 consent orders. $^{8}$

\footnotetext{
${ }^{5} I d$. (emphasis added).

${ }^{6}$ In the Matter of Bank of America, NA, Case No.: AA-EC-11-12, Consent Order (Office of the Comptroller of the Currency, Apr. 13, 2011) (online at www.occ.gov/news-issuances/news-releases/201 1/nr-occ-201 l-47b.pdf).

${ }^{7}$ Id.

${ }^{8}$ Board of Governors of the Federal Reserve System and Office of the Comptroller of the Currency, Joint Press Release (Jan. 7, 2013) (online at www.occ.gov/news-issuances/news-releases/2013/nr-ia-2013 -3 .html).
} 
The Honorable Ben Bernanke

The Honorable Thomas Curry

Page 5

On February 28, 2013, formal agreements were executed in which these servicers agreed to pay $\$ 9.3$ billion in "cash payments and other assistance" to borrowers, including \$3.6 billion in direct payments to borrowers who had homes in foreclosure in 2009 or $2010 .{ }^{9}$

Significant questions have been raised by this decision, including the extent of abuses identified during the review and whether the sum the banks agreed to pay was appropriate to fully compensate borrowers for the legal violations committed. At our meeting yesterday, your staff refused to identify the number of violations or errors found during the review process committed by each mortgage servicer that entered into an amended consent order. Your staff also stated that they had not decided whether to provide individual borrowers with information identified during the review process about the harm their own mortgage servicers may have caused so they could seek redress. In addition to providing information about these abuses to Members of Congress, we believe you should disclose to borrowers information in your possession that would help them address the harm they suffered.

\section{Declining to Produce Documents Relating to Violations of Law}

In response to our request for documents relating to violations of law committed by mortgage servicing companies, your staff made two arguments: first, that documents relating to these widespread violations are the "trade secrets" of mortgage servicing companies; and second, that these documents should be withheld from Congress to avoid waiving the authority to withhold bank examination materials from the public. We believe the decision not to provide these documents is a mistake, and we respectfully request that you reconsider your staffs approach.

First, according to the Court of Appeals for the District of Columbia Circuit, the definition of a "trade secret" is:

[A] secret, commercially valuable plan, formula, process, or device that is used for the making, preparing, compounding, or processing of trade commodities and that can be said to be the end product of either innovation or substantial effort. ${ }^{10}$

Obviously, this definition does not encompass illegal activity. It would be very surprising indeed if mortgage servicing companies argued that their ability to engage in illegal

${ }^{9}$ Board of Governors of the Federal Reserve System and Office of the Comptroller of the Currency, Joint Press Release (Feb. 28, 2013) (online at www. federalreserve. gov/newsevents/press/enforcement/2013 022 8a.htm).

${ }^{10}$ Public Citizen Health Research Group v. FDA, 704 F.2d 1280, 1288 (D.C. Cir. 1983) (citing Restatement (First) of Torts $§ 757 \mathrm{cmt}$. b (1939) ("A trade secret may consist of any formula, pattern, device or compilation of information which is used in one's business, and which gives him an opportunity to obtain an advantage over competitors who do not know or use it"). 
The Honorable Ben Bernanke

The Honorable Thomas Curry

Page 6

foreclosures and charge inflated fees is a commercially viable plan derived from corporate "innovation."

Second, your staff argued that producing these documents to Members of Congress who are not Committee chairs could be viewed as a waiver of your agencies' authority to withhold confidential and proprietary information from the public. This argument is misplaced. You may protect against such a waiver by including standard language in a cover letter explaining that providing documents to Members of Congress, even if normally not disclosed to the public because of their proprietary or confidential nature, does not constitute a waiver.

Other agencies and offices have taken precisely this approach. For example, on May 24, 2012, the Federal Housing Finance Agency (FHFA) provided documents relating to mortgage servicing issues in response to a request from Ranking Member Cummings and Oversight Committee Member John Tierney. In its cover letter, FHFA stated:

FHFA staff has collected documents responsive to your requests and compiled these in the attached disks.... Materials provided include information related to the Enterprises and to FHFA internal deliberations that, in many cases, fall within the category of proprietary, confidential, non-public information that would not be released by FHFA. ${ }^{11}$

Finally, your staff referenced regulations protecting against public disclosure of "bank examination" and "confidential supervisory information." These regulations make clear that, although you may choose to deny our requests because they do not come with the threat of a Committee subpoena, you have discretion to comply with such requests when they serve the nation's interests, as this one does. ${ }^{12}$ These regulations are based on exemptions to the Freedom of Information Act (FOIA), which states that it is "not authority to withhold information from Congress." More than 30 years ago, the Department of Justice issued the following guidance on responding to requests from Members of Congress:

\footnotetext{
${ }^{11}$ Alfred M. Pollard, General Counsel, Federal Housing Finance Agency, to Ranking Member Elijah E. Cummings and Ranking Member John F. Tierney, House Committee on Oversight and Government Reform (May 24, 2012). See also Alfred M. Pollard, General Counsel, Federal Housing Finance Agency, to Ranking Member Elijah E. Cummings and Ranking Member John F. Tierney, House Committee on Oversight and Government Reform (Apr. 12, 2012) ("FHFA has collected documents responsive to your request and this production reflects the materials from Fannie Mae and Freddie Mac that relate to the pilot programs. The documents from Fannie Mae and Freddie Mac (Enterprises) contain confidential, proprietary, nonpublic information that would not be released by the FHFA or the Enterprises.").

${ }^{12}$ See 12 C.F.R. $\S 4.36$ (governing OCC discretion to disclose non-public information); and 12 C.F.R. $§ 261.22$ (governing the Federal Reserve's discretion to disclose non-public information).
} 
The Honorable Ben Bernanke

The Honorable Thomas Curry

Page 7

From a policy perspective, there is significant practical importance in maintaining a proper flow of information not only to Congress and its committees and subcommittees but also to individual members. ... Thus, when Members of Congress request information, agencies properly give due weight and sympathetic consideration. The legislator may have a need for access to documents which fall outside the public's right to know under FOIA. The individual member may seek information in his or her official capacity to assist a constituent, to develop and decide on proposed legislation, or to participate in the work of committees or subcommittees to which the member may belong or before which the member may appear. An agency should not lightly deny a request even for records exempt under FOIA if the member of Congress needs the records to carry out an official function. ${ }^{13}$

In updating those guidelines several years later, the Department advised that releasing information to Members of Congress does not impact the ability to use applicable FOIA exemptions in response to other requests:

Recognizing the importance of federal information flow to effective congressional relations, Executive Branch agencies should of course give very careful consideration to any access request received from a Member of Congress, with discretionary disclosure often a possibility. And where an agency makes such a discretionary disclosure in furtherance of a legitimate governmental interest, together with careful restrictions on further dissemination, it should be able to resist an argument that such action constitutes a "waiver" of FOIA exemptions. $^{14}$

\section{GAO Study Finds Extensive Flaws with IFR Process}

Last week, GAO issued a report describing significant flaws with the design and implementation of the IFR, as well as a lack of transparency that has undermined confidence in its findings. For example, although the independent consultants were directed "to identify as many harmed borrowers as possible and ensure similar results for similarly situated borrowers," GAO warned that "regulators' limited monitoring of consistency of the consultants' sampling methodologies and review processes" actually "risked not achieving the intended goals." GAO warned that "this remains a challenge for the servicers continuing the foreclosure review." Specifically, GAO concluded:

${ }^{13}$ Department of Justice, Office of Information Policy, Release of Exempt Information to Members of Congress: The Impact of the Murphy Decision, FOIA Update, Vol. I, No. 4 (1980)

(online at www .justice. gov/oip/foia_updates/Vol_I_4/page3. htm).

${ }^{14}$ Department of Justice, Office of Information Policy, Congressional Access Under FOIA, FOIA Update, Vol. V, No. 1 (1984) (online at www .justice. gov/oip/foia_updates/Vol_V_l/page3 .htm). 
The Honorable Ben Bernanke

The Honorable Thomas Curry

Page 8

Our analysis found that the regulators' sampling approach did not include mechanisms to facilitate their oversight of the extent to which consultants would have reached as many harmed borrowers as possible. For example, the regulators' sampling approach did not provide an objective method for regulators to use in determining if consultants had conducted sufficient reviews and could stop their review activities, except in those cases where there were few or no errors. ...

In addition, the regulators' sampling approach did not provide a clear mechanism for regulators to assess the extent to which consultants had identified the appropriate high-and low-risk loan categories to confirm that those categories were accurate and to signal if there were additional potential high-risk loan categories that had not been identified, but warranted additional sampling and review. 15

As your staffs conceded yesterday, foreclosure reviews for 11 mortgage servicers have now been terminated even though only a fraction of the files identified for review have been completed and even though the sampling techniques and oversight methodologies have not enabled regulators to determine the full extent of harm suffered by borrowers.

Despite these deficiencies, GAO reported that now, "[u]sing a framework provided by regulators and characteristics of borrowers' loans, servicers will categorize borrowers, and regulators will develop a distribution plan and direct a payment administrator to distribute cash payments. ${ }^{16}$ In other words, the same mortgage servicers that you determined had engaged in widespread abuses are now placing borrowers into categories to receive remediation based on a review process that GAO has found to be deeply deficient.

GAO reported that your offices "did not describe plans to release additional information about the procedures servicers are using to categorize borrowers" and stated that "neither regulator had made decisions about what information to provide to borrowers."17 In addition, as your staffs conceded yesterday, borrowers will have no mechanism by which to contest their placement in a certain category or the level of remediation offered to them.

GAO proposed significant changes going forward, recommending that your offices "identify and apply lessons from the foreclosure review process, such as enhancing planning and monitoring activities to achieve goals, as they develop and implement the activities under the amended consent orders." GAO also warned: "Absent a clear strategy to guide regular communications with individual borrowers and the general public, regulators face risks to transparency and public confidence similar to those experienced in the foreclosure review."

\footnotetext{
${ }^{15}$ Government Accountability Office, Foreclosure Review: Lessons Learned Could Enhance Continuing Reviews and Activities Under Amended Consent Orders (GAO-13-277) (Apr. 4, 2013) (online at www.gao.gov/products/GAO-13-277).

${ }^{16} I d$. (emphasis added).

${ }^{17} I d$.
} 
The Honorable Ben Bernanke

The Honorable Thomas Curry

Page 9

\section{Conclusion}

Given the circumstances of this case - in which your offices have identified systemic and widespread violations of federal law, including wrongful foreclosures, excessive fees, and fraudulent affidavits filed in court — access by Members of Congress to additional information about these violations is not only warranted, but imperative. For these reasons, we hope that you will reconsider your staff's positions and work with us to achieve a mutually agreeable accommodation that serves both of our interests. Thank you for your continued assistance.

Sincerely,

Elizabeth Warren

Member of Congress
Elijah E. Cumming s

Member of Congress

cc: The Honorable Tim Johnson, Chairman, Senate Committee on Banking, Housing and Urban Affairs

The Honorable Mike Crapo, Ranking Member, Senate Committee on Banking, Housing and Urban Affairs

The Honorable Sherrod Brown, Chairman, Subcommittee on Financial Institutions and Consumer Protection

The Honorable Pat Toomey, Ranking Member, Subcommittee on Financial Institutions and Consumer Protection

The Honorable Robert Menendez, Member, Senate Committee on Banking, Housing and Urban Affairs

The Honorable Darrell E. Issa, Chairman, House Committee on Oversight and Government Reform

The Honorable Jeb Hensarling, Chairman, House Committee on Financial Services

The Honorable Maxine Waters, Ranking Member, House Committee on Financial Services 
The Honorable Ben Bernanke

The Honorable Thomas Curry

Page 10

\begin{tabular}{|c|c|}
\hline Warren/Cummings Request & $\begin{array}{l}\text { Federal Reserve/OCC } \\
\text { Response }\end{array}$ \\
\hline $\begin{array}{l}\text { 1. Performance reviews: The results of all performance reviews conducted by } \\
\text { the Federal Reserve or the OCC over the Independent Foreclosure Review, } \\
\text { including: } \\
\text { a. all documents reviewing the performance of each of the independent } \\
\text { contractors engaged by mortgage servicers to conduct reviews of borrower } \\
\text { files under the terms of the consent orders issued in April } 2011 \text {, } \\
\text { b. all documents detailing the nature of any instances of unsatisfactory } \\
\text { performance found by the Federal Reserve or the OCC, } \\
\text { c. all documents detailing any corrective actions ordered by the Federal } \\
\text { Reserve or the OCC to be taken by any mortgage servicer subject to the April } \\
2011 \text { consent orders or by any independent contractor conducting borrower file } \\
\text { reviews, and } \\
\text { d. all documents describing the adequacy of any corrective action taken by any } \\
\text { mortgage servicer subject to the April } 2011 \text { consent order or by any } \\
\text { independent contractor engaged to review borrower files; }\end{array}$ & $\begin{array}{l}\text { 1. No response. } \\
\text { la. No response. } \\
\text { lb. No response. } \\
\text { lc. } \underline{\text { No response. }} \\
\text { Id. No response }\end{array}$ \\
\hline $\begin{array}{l}\text { 2. Updates to OCC/Fed from servicers and consultants: All } \\
\text { documents and reports prepared by the mortgage servicers subject to the } \\
\text { April } 2011 \text { consent orders or the independent contractors engaged by } \\
\text { mortgage servicers to conduct reviews of borrower fdes under the terms of } \\
\text { the consent orders issued in April 2011, describing, reviewing, or updating } \\
\text { on the Independent Foreclosure Review process, and supplied to the OCC or } \\
\text { the Federal Reserve; and, }\end{array}$ & 2. No response. \\
\hline $\begin{array}{l}\text { 3. Amounts paid to consultants: All documents compiled by the Federal } \\
\text { Reserve or the OCC indicating the total amount of settlement funds paid to } \\
\text { each independent contractor engaged by the } 14 \text { mortgage servicers subject } \\
\text { to the April } 2011 \text { consent orders and all documents compiled by the Federal } \\
\text { Reserve or the OCC indicating itemizations of specific work performed by } \\
\text { each contractor. }\end{array}$ & $\begin{array}{l}\text { 3. Minimal response: The } \\
\text { OCC and Fed have disclosed } \\
\text { the total amount spent on the } \\
\text { consultants - } \$ 2 \text { billion - but } \\
\text { no documents have been } \\
\text { provided that detail the } \\
\text { amount paid to each } \\
\text { contractor or that itemize the } \\
\text { specific work performed by } \\
\text { each }\end{array}$ \\
\hline
\end{tabular}


The Honorable Ben Bernanke The Honorable Thomas Curry Page 11

\begin{tabular}{|c|c|}
\hline & contractor. \\
\hline $\begin{array}{l}\text { 4. Information on borrowers: The total number of eligible borrowers } \\
\text { who requested reviews of their foreclosure fdes by gender, race, zip code, } \\
\text { and property value }\end{array}$ & $\begin{array}{l}\text { 4. Minimal response: The OCC and } \\
\text { Fed have disclosed the total number } \\
\text { of eligible borrowers who requested } \\
\text { reviews and, in September } 2012 \text {, the } \\
\text { Federal Reserve and the OCC } \\
\text { released county-by-county data on } \\
\text { (1) borrowers mailed a form to } \\
\text { request a file review and (2) } \\
\text { borrowers who submitted a request } \\
\text { for review up to that date. However, } \\
\text { no data broken down by gender, race, } \\
\text { zip code, and property value have } \\
\text { been provided. }\end{array}$ \\
\hline $\begin{array}{l}\text { 5. IFR findings: The total number of reviews of borrower fdes } \\
\text { initiated by each of the independent contractors engaged by the } \\
14 \text { mortgage servicers subject to the April } 2011 \text { consent orders, } \\
\text { including } \\
\text { a. the number of reviews completed by January 7, } 2013 \text { by } \\
\text { each independent contractor, } \\
\text { b. the number of borrower fdes in which unsafe or } \\
\text { unsound practices were found, } \\
\text { c. the amount of remediation each borrower who } \\
\text { experienced an unsafe or unsound practice was } \\
\text { recommended to receive, and } \\
\text { d. the amount of remediation paid out to borrowers as part of the } \\
\text { Independent Foreclosure Review process; and }\end{array}$ & $\begin{array}{l}\text { 5. Partial response: The OCC and } \\
\text { Fed have disclosed the total } \\
\text { number of borrower fdes } \\
\text { identified for review - } 744,685 \text { - } \\
\text { but these have not been broken } \\
\text { down by consultant. } \\
5 \text { a. Partial response: The OCC } \\
\text { and Fed have identified the total } \\
\text { number of reviews completed - } \\
103,820 \text {-but these have not been } \\
\text { broken down by consultant. } \\
5 b . \text { No response. } \\
5 c . \text { No response. } \\
\text { 5d. Full response. The OCC and Fed } \\
\text { have indicated that no remediation } \\
\text { has been paid out. }\end{array}$ \\
\hline $\begin{array}{l}\text { 6. Consultant time spent per file: The average time each independent } \\
\text { contractor engaged by the } 14 \text { mortgage servicers subject to the April } \\
2011 \text { consent orders required to complete a review of a borrower's file. }\end{array}$ & 6. No response. \\
\hline
\end{tabular}




\title{
APPENDIX B 07.06.2015 Letter to Snohomish County Auditor
}

July 6, 2015

\author{
James Campbell \\ 9209 NE $173^{\text {rd }} \mathrm{Pl}$. \\ Bothell, WA 98011 \\ Ms. Carolyn Weikel \\ Snohomish County Auditor \\ 3000 Rockefeller Ave. \\ Everett, WA 98201 \\ Re: Fraudulent Recordings \\ Dear Ms. Weikel:
}

I am a candidate for a Master's Degree in Policy Studies at the University of Washington Bothell which I will complete in June, 2016. For my Master's capstone, I have chosen a project which will examine the protocol for the recording of certain documents which affect the titles to real property. In particular, I will be focusing exclusively on the recording of trust deed assignments to real estate mortgage investment conduits (REMICs) in Snohomish County between 2008 and the present. The importance of this research is grounded in the mistaken but common public perception that if a document is recorded with a county auditor by a major financial institution, then it must be genuine.

In preparation for my capstone, I gathered data on a random sampling of 151 Snohomish County foreclosures which were started in 2012. Of those 151 samples, I determined that 21 (equating to 14\%) of them were begun unlawfully due to the fact that the REMIC assignments were legal nullities. Copies of those 21 documents are enclosed. Also enclosed is the abstract of a research paper I wrote in 2013 entitled The Nexus of Fabricated Mortgage Loan Assignments and Unlawful Foreclosures ${ }^{1}$.

I am furnishing you with this information because, based upon the research I have conducted to date, there is no longer any question that bogus DOT assignments are routinely filed for recording in Snohomish County. Each time one of your counter staff records a fraudulent assignment, a violation of RCW 9.38.020 occurs. I will argue that the Snohomish County Records Division is required by law to cease its practice of recording legal nullities ${ }^{2}$ (meaning certain fraudulent deed of trust assignments to REMICs) because such recordings are false representations concerning title. The recording of false representations violates: $\boldsymbol{R C W}$ 9.38.020 False representation concerning title.

"Every person who shall maliciously or fraudulently execute or file for record any instrument, or put forward any claim, by which the right or title of another to any real or

\footnotetext{
1 The complete text can be downloaded from: http://papers.ssrn.com/sol3/papers.cfm?abstract_id=2462778

2 "The MERS Assignment is, so far as the court can ascertain, a legal nullity." See: Knecht v. FIDELITY NATIONAL TITLE INSURANCE COMPANY, et al., Case 2:12-cv-01575-RAJ, dkt. 140, p. 11, (W.D. Wash. 2015)
} 


\section{personal property is, or purports to be transferred, encumbered or clouded, shall be} guilty of a gross misdemeanor."

Snohomish County DOT assignment recording policies enable the processing of unlawful foreclosures because they lack a screening protocol to verify whether or not the assignments they accept for recording have been lawfully prepared. I hasten to add that in the past, County personnel including you, likely did not know that they were violating RCW 9.38.020. It is also likely that the particular individuals who appear at the counter are unaware that they are presenting bogus documents for recording. On both sides of the counter, people are simply doing their jobs as directed by their employers. However if either the presenters of such documents or the County employees who accept them gain the expertise to easily identify bogus DOT assignments, and record them anyway, they could be subjecting themselves to prosecution for each individual violation of RCW 9.38.020. The purpose of this letter (and attachments to it) is to furnish you with that expertise. Your staff cannot legally continue to record these assignments if they have knowledge that in doing so, they are willingly violating the law.

Because these assignments are recorded with no questions asked, the assignees (which are invariably major financial institutions), routinely cite them in both non-judicial foreclosures and court filings as evidence that they have been assigned the right to foreclose. In those rare instances where homeowners successfully stop a foreclosure by challenging these unlawful assignments, the usual "punishment" to the bank for attempting such a thing is merely the cancellation of the foreclosure process. More often than not, however, judges also don't question the validity of these assignments based solely on the fact that some large financial institution placed them in the public record. Because they usually prevail, there is no incentive for them to stop this practice. It is so lucrative that it will never stop unless the appropriate authorities step in and disrupt the process early-on. In Snohomish County, that responsibility appears to fall on you personally.

The fraudulent DOT assignments I am referring to are not difficult to identify. Referring to the 21 enclosed documents, you will notice three shared characteristics:

1. The assignee is always a major financial institution acting as the trustee of some securitized trust that was created in 2007 or earlier.

2. Within the name of the securitized trust, the year that the trust was created (in numeric form -- all four digits) is always featured.

3. The execution of the assignment always occurred on some date in 2008 or later. Usually, the execution date is quite recent, meaning sometime within the previous 30 days or so.

I am recommending that, as a matter of responsible public policy, you should direct your staff to be on the lookout for assignments that fit the three criteria cited above; and decline to record them. I do realize that if you act on my recommendation, you will immediately become a controversial figure. You will likely become a defendant in lawsuits brought by some of the most powerful financial entities in the world. But considering that these fraudulent assignments are always followed up with foreclosure attempts, you have a duty as a public servant to act in the best interests of the people you serve. You must stop facilitating unlawful foreclosures against unfortunate homeowners who, at perhaps the most vulnerable period in their lives, are routinely victimized by these rogue financial institutions.

Thank you in advance for your consideration and I would appreciate a written acknowledgement that you received this correspondence. Feel free to contact me at any time if you wish.

Respectfully,

James Campbell

206-427-5653 
Master of Arts in Policy Studies (MAPS) Program jc68@uw.edu

encl: Nexus Abstract

Twenty-One DOT Assignments

Abstract:

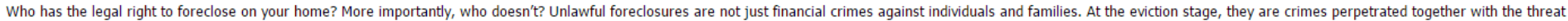

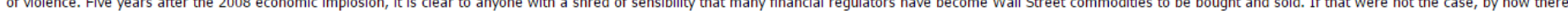

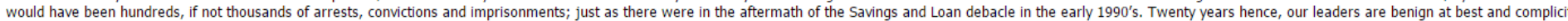

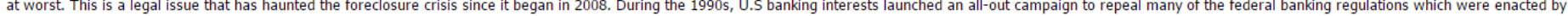

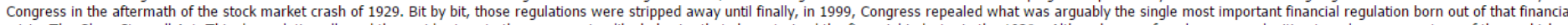

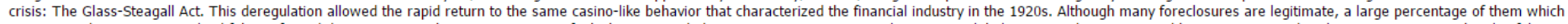

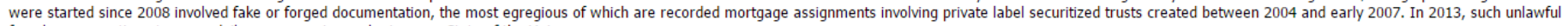
foreclosures continue to occur daily, on a massive scale, in every State of the Union.

Number of Pages in PDF File: 81

Keywords: Foreclosure, securitization, mortgage, MERS, Glass-Steagall, Ponzi Scheme, OCC, Independent Foreclosure Review, Mortgage Backed Securities, Elizabeth Warren, Graham-Leach-Bliley JEL Classification: A14, A23, B25, D23, D63, K11, K42

\begin{tabular}{|l|l|l|}
\hline & $\begin{array}{c}\text { List of Assignments } \\
\text { (Recording Numbers) }\end{array}$ & \multicolumn{1}{|c|}{ Trustee } \\
\hline 1 & 200804250762 & Deutsche \\
\hline 2 & 201201110269 & Deutsche \\
\hline 3 & 201206060268 & Citibank \\
\hline 4 & 200804160313 & HSBC \\
\hline 5 & 200811200348 & LaSalle \\
\hline 6 & 200907060045 & B of A \\
\hline 7 & 200907130040 & U.S. Bank \\
\hline 8 & 200907300334 & Citibank \\
\hline 9 & 201005170023 & U.S. Bank \\
\hline 1 & 201007140392 & Citibank \\
\hline
\end{tabular}

\begin{tabular}{|l|l|l|}
\hline & \multicolumn{1}{|c|}{$\begin{array}{c}\text { List of Assignments } \\
\text { (Recording Numbers) }\end{array}$} & \multicolumn{1}{|c|}{ Trustee } \\
\hline 11 & 201007160322 & Mellon \\
\hline 12 & 201105170217 & HSBC \\
\hline 13 & 201110120005 & HSBC \\
\hline 14 & 201110170415 & Mellon \\
\hline 15 & 201111040597 & Deutsche \\
\hline 16 & 201112230312 & Deutsche \\
\hline 17 & 201204190370 & HSBC \\
\hline 18 & 201204200312 & Deutsche \\
\hline 19 & 201205160353 & U.S. Bank \\
\hline 20 & 201206110298 & Citibank \\
\hline 21 & 201211140851 & Citibank \\
\hline
\end{tabular}


James Campbell | Master of Arts in Policy Studies

University of Washington Bothell | June 6, 2016

An Inquiry into the Legal Standing of Rogue REMICs in Foreclosures

\section{APPENDIX C 07.14.2015 Letter from Snohomish County Auditor}

\section{$4 \uparrow \uparrow$ \\ Snohomish County \\ Auditor's Office}

Carolyn Weikel

County Auditor

Connie Barndt

Chief Doputy Auditor

James Campbell

9209 NE $173^{\text {rd }} \mathrm{PL}$

Bothell, WA 98011

July 14,2015

Mr. Campbell,

As requested, I writing to confirm that I received your letter and attachments dated July 6, 2015 regarding concerns about the recording of fraudulent documents in Snohomish County.

While I believe that my staff is acting appropriately in receiving and recording documents that meet statutory recording requirements, I have forwarded your concerns to our deputy prosecuting attorney for review.

Thank you for sharing this information with our office.

Sincerely,

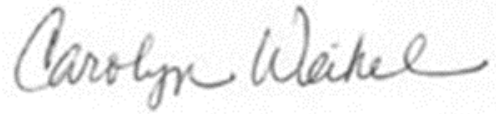

Carolyn Weikel 


\title{
APPENDIX D 07.30.2015 Letter to Snohomish County Prosecuting Attorney
}

\author{
James Campbell \\ 9209 NE $173^{\text {rd }} \mathrm{Pl}$. \\ Bothell, WA 98011 \\ Mr. Christopher Dickinson \\ Snohomish County Deputy Prosecutor \\ 3000 Rockefeller Avenue \\ $\mathrm{M} / \mathrm{S} 504$ \\ Everett, WA 98201 \\ Re: Fraudulent Recordings \\ Dear Mr. Dickinson:
}

I am following up on a recent correspondence exchange I had with Ms. Carolyn Weikel, Snohomish County Auditor. A copy of my July 6,2015 letter to her, and the attachments to it are enclosed. Also enclosed is a copy of her response. I would appreciate a written acknowledgement from your office that you did receive a correspondence from Ms. Weikel regarding this matter and that you did receive this correspondence from me. Thank you.

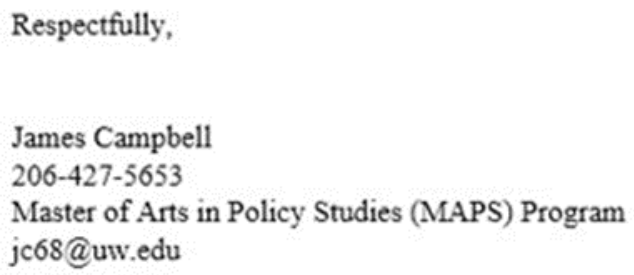

ehcl: Twenty-One DOT Assignments

cc: Carolyn Weikel 


\section{APPENDIX E 08.05.2015 Letter from Snohomish County Prosecuting Attorney}

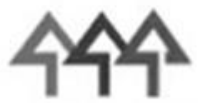

Snohomish County Prosecuting Attorney Mark K. Roe
Civil Division Jason J. Cummings, Chief Deputy Robert J. Drewel Building, $8^{\text {w }}$ Floor, M/S 504 3000 Rockefeller Ave Everett, WA 98201-4060 (425) 388.6330 Fax (425) 388-6333

August 5, 2015

James Campbell

$9209 \mathrm{NE} 173^{\text {nd }} \mathrm{Pl}$.

Bothell, WA 98011

\section{Re: Your Letter Dated July 30, 2015}

Dear Mr. Campbell:

This office received your letter, directed to criminal Deputy Prosecuting Attorney Chris Dickinson, dated July 30, 2015, on August 5, 2015. Your letter asks for confirmation that the Snohomish County Auditor provided certain correspondence to the Prosecuting Attorney's Office. Requests for legal advice from the Snohomish County Auditor, or any documents provided in order to obtain such advice, are protected by the attomey client privilege. RCW $5.60 .060(2)$. Thus, we respectfully decline to provide you with the information requested.

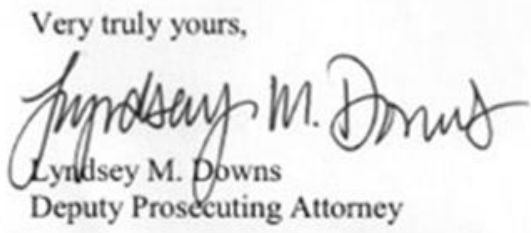

cc: client

Chris Dickinson, DPA 


\section{APPENDIX F 08.17.2015 Letter to Snohomish County Prosecuting Attorney}

James Campbell $9209 \mathrm{NE} 173^{\text {s }} \mathrm{Pl}$.

Bothell, WA 98011

Ms. Lyndsey Downs

Snohomish County Deputy Prosecutor

3000 Rockefeller Avenue

MS 504

Everett, WA $9 \$ 201$

Re: Fraudulent DOT Assignments

Dear Ms. Downs:

Thank you for your letter of August 5,2015. I would have preferred an allied relationship with the Prosecuting Attorney in this matter rather than adversarial one. But if I interpreted your letter correctly, that may not be possible.

I don't believe I requested legal advice from you or the Auditor and I apologize if that was the interpretation. I am considering a complaint under Rule CrRLJ 2.1. I am not requesting legal advice at this time either but I do need some clarification. One question under the CrRLJ 2.1(5)(a) segment of the complaint form is whether or not I consulted with the Prosecuting Attomey before filing the complaint. Should I consider my letter to Mr. Dickinson and your letter to me to be a consultation? That's fine if you have nothing further to add but I do wish to answer the question accurately.

I have attached a draft of that complaint (it's a work in progress), as well as two documents in support of it. If you read them, you might conclude that a voluntarily moratorium on recording these types of assignments is not such a bad idea after all. It would certainly make my capstone a much more pleasant endeavor!

You can respond to me in writing (USPS) or by email - your choice. But please do respond as I wish to proceed without delay. Thank you.

Respectfully,

James Campbell

206-427-5653

Candidate | Master of Arts in Policy Studies

University of Washington Bothell

jc68@uw.edu

encl: Complaint (draft)

Dirt Lawyers, Dirty Remics

John O'Brien Presentation 


\title{
APPENDIX G 08.26.2015 Letter from Snohomish County Prosecuting Attorney
}

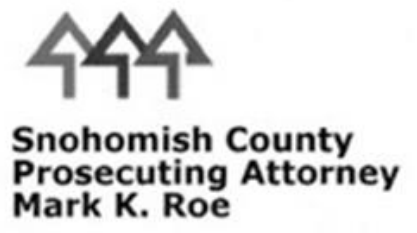

Civil Division

Jason J. Cummings, Chief Deputy Robert J. Drewel Building, $8^{\text {th }}$ Floor, M/S 504 3000 Rockefeller Ave Everett, WA 98201-4060 (425) $388-6330$ Fax (425) 388-6333

August 26, 2015

\begin{abstract}
James Campbell $9209 \mathrm{NE} 173^{\text {rd }} \mathrm{Pl}$.

Bothell, WA 98011
\end{abstract}

\section{Re: Your Letter Dated August 17, 2015}

Dear Mr. Campbell:

This letter confirms that in a letter dated July 30 , received by the Prosecuting Attorney's Office on August 5, you provided information related to your allegations that the Snohomish County Auditor's Office is recording fraudulent Deeds of Trust. In a subsequent letter dated August 17, received on August 24, you provided a draft copy of a citizens complaint reiterating the same allegations. Whether the letters constitute consultation with the prosecuting authority pursuant to CrRL 2.1(5)(c) is a legal determination that we leave to the court.

Please note that your allegations in this matter are based on a misunderstanding of the auditor's statutory recording duty. The function of a County Auditor in accepting and recording an instrument which is presented to him or her for recording is a purely ministerial function. RCW 65.08.150. The Auditor must record documents that are statutorily authorized, appropriate as to form, and accompanied by the proper fee. Eggert v. Ford, 21 Wn.2d 152, 154, 150 P.2d 719 (1944). Recording an instrument is not a certification or representation by a County Auditor that the instrument is valid or will have the legal effect intended by the parties.

If you believe that there are defects in Deeds of Trust recorded by the Snohomish County Auditor, you may wish to address the validity of a Deed of Trust with the parties to the transaction and/or to any third parties subsequently dealing with the same property.

cc: client

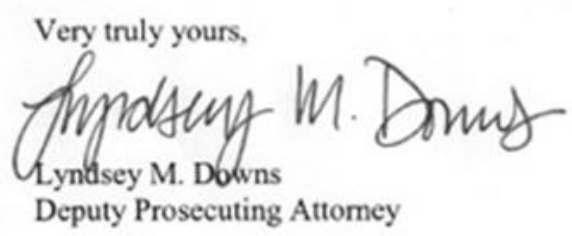

\begin{tabular}{|c|c|c|}
\hline Administration & Criminal Division & Family Support Division \\
\hline Robert G. Lenz, Operations Manager & Joan Cavagnaro, Chief Deputy & Serena S.A. Hart, Chief Deputy \\
\hline Mission Building & Mission Building & Robert J. Drewel Bidg., $6^{\text {th }}$ Floor \\
\hline (425) $388-3333$ & (425) $388-3333$ & $(425) 388-7280$ \\
\hline Fax (425) $388-7172$ & Fax (425) $388-3572$ & Fax (425) $388-7295$ \\
\hline
\end{tabular}




\section{APPENDIX H 09.08.2015 Letter to Snohomish County Prosecuting Attorney}

James P. Campbell

9209 NE $173^{\text {rd }}$ P1.

Bothell, WA 98011

Ms. Lyndsey Downs

Snohomish County Deputy Prosecutor

3000 Rockefeller Avenue

$\mathrm{M} / \mathrm{S} 504$

Everett, WA 98201

\section{Re: Fraudulent DOT Assignments}

Dear Ms. Downs:

I am in receipt of your letters of August 26 and September 1, 2015. Thank you for explaining your legal stance with regard to your client. Based upon my previous two letters to you, it should be apparent that it is not my primary objective to attack your client. My objective is putting a stop to unlawfully recorded assignments by whatever legal means necessary. Ms. Weikel just happens to be involved in that process. That said, I will no longer press the issue with you with regard to Ms. Weikel's legal responsibilities.

I still argue that the DOT assignments that I have identified (and similar assignments as weil) are unlawful clouds on title. In your letter of August 28 , you did not comment on those allegations but suggested that they should be directed toward the parties involved in preparing those documents rather than toward your client. I agree and I am quite willing to swear out an affidavit alleging criminal activity by one or more of those parties, if need be, rather than implicating Ms. Weikel. But as you could probably surmise, any judge reviewing such a complaint would probably want to know if the Prosecutor agrees that these criminal charges might indeed have some merit.

I have furnished you with compelling arguments (not just personal opinions) explaining why the recording of assignments to closed REMICs are criminal acts under Washington State law. With all of the research I conducted since 2008 , I have yet to find any credible evidence to the contrary. Instead, I am continuing to compile scholarly writings and case law from around the country that all point to the same thing:

- People are being foreclosed upon with fraudulently recorded documentation.

- The parties who are doing this have no standing to foreclose.

- They never had any skin in the game in the first place. 
You've convinced me that pursuing criminal charges against the Auditor would likely be a nonstarter in Superior Court. And she is understandably reluctant to be an auditor-activist like John O'Brien. But the fact remains that there are white collar criminals, utilizing the Snohomish County Records Division, who have been unlawfully preying upon homeowners with impunity since the beginning of the financial crisis. The principals of these financial institutions and their agents continue to make a mockery of Washington's criminal justice system to this day. So before I proceed further, would you at least consider undertaking a criminal investigation of your own? If so, I am at your disposal to assist you in any way I can. Thank you.

Respectfully,

/s/ James P. Campbell

James P. Campbell

206-427-5653

Candidate | Master of Arts in Policy Studies

University of Washington Bothell

jc68@uw.edu 
James Campbell | Master of Arts in Policy Studies

University of Washington Bothell | June 6, 2016

An Inquiry into the Legal Standing of Rogue REMICs in Foreclosures

\section{APPENDIX I 09.26.2015 Online Message to Washington Attorney General}

\begin{tabular}{|c|c|}
\hline From: & Campbell, James Patrick \\
\hline Email Address: & jc68@uw.edu \\
\hline \multirow{2}{*}{ Address: } & 9209 \\
\hline & Bothell WA 98011 \\
\hline Address Type: & Home \\
\hline Phone: & Phone Type: \\
\hline Subject: & Unlamil Foreciosures \\
\hline \multicolumn{2}{|l|}{ Message: } \\
\hline \multicolumn{2}{|r|}{ 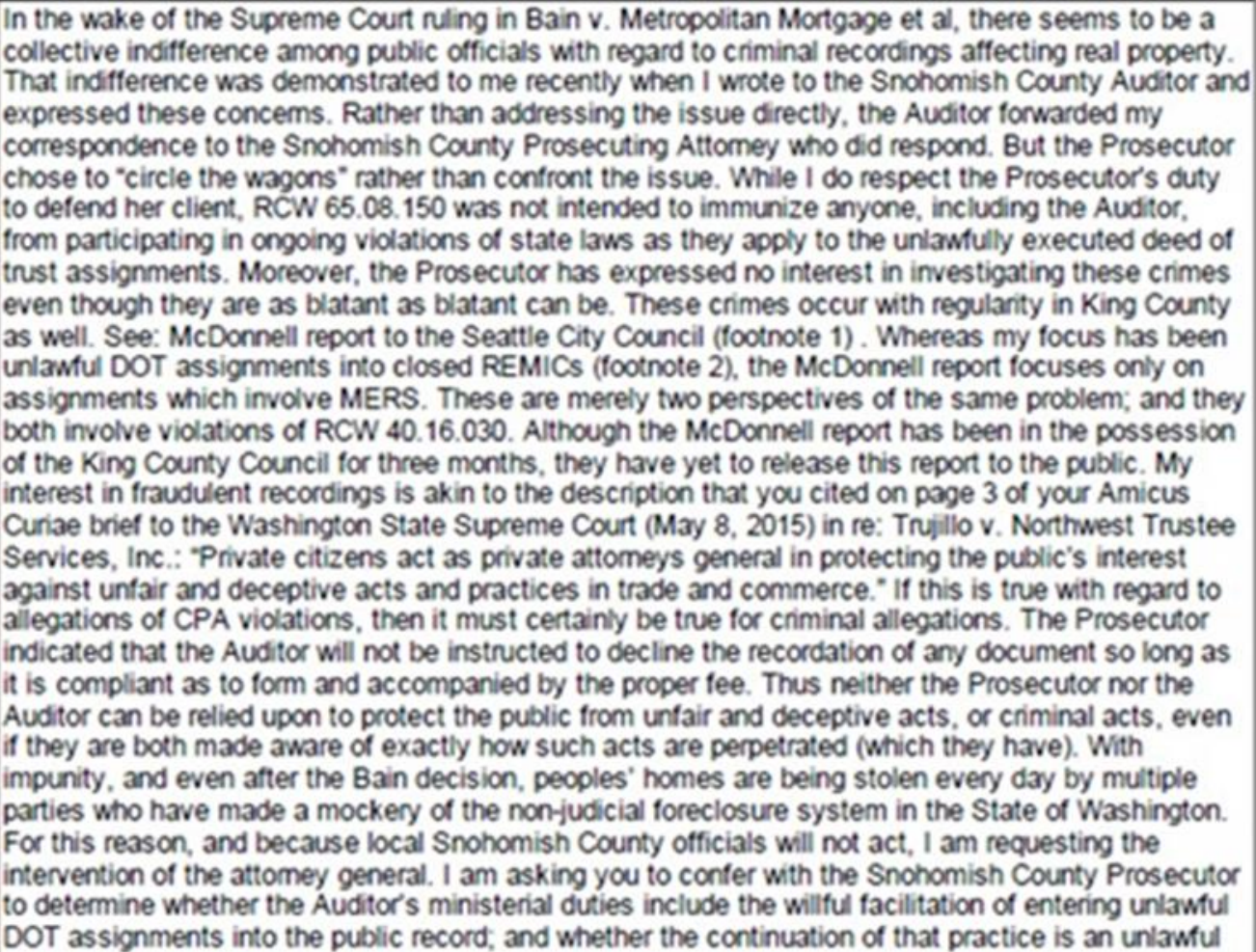 } \\
\hline
\end{tabular}

\begin{tabular}{|c|c|c|c|}
\hline \multicolumn{4}{|c|}{ UW Mal - Thurk You for Corbetion the AGO } \\
\hline \multicolumn{4}{|c|}{ 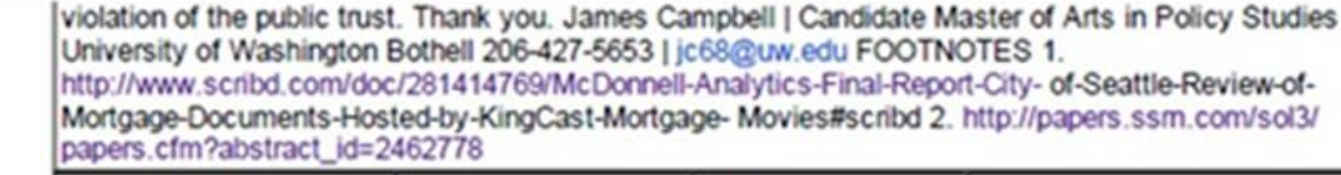 } \\
\hline Previous Contact: & No & Date: & \\
\hline \multicolumn{4}{|l|}{ Regarding: } \\
\hline \multicolumn{4}{|c|}{ Declared By Name and Date: } \\
\hline Name: & James Campbell & Date: & $09 / 24 / 2015$ \\
\hline Submitted on: $9 / 24$ & 12:02 PM & & \\
\hline
\end{tabular}




\section{APPENDIX J 10.07.2015 Online Response from Washington Attorney General}

Mr. Campbell,

Thank you for your correspondence. The Attorney General's Office takes the issue of improper nonjudicial foreclosures - and any associated inaccurate recordings - very seriously. We are aware of the McDonnell Analytics report to the Seattle City Council, although to my knowledge we had (and have) no involvement with it. We are also aware of the Seattle City Auditor and City Attorney's concerns about that report. A copy of the report, posted with the Auditor's statement explaining why it does not endorse the report, is publicly available at http://www.seattle.gov/cityauditor. We are not in a position to second-guess the City Auditor or Attorney, particularly to the extent their concerns are directed toward the issue of whether the McDonnell report provides the City Council with the information it sought.

If you have specific assignments of deeds of trust that you believe are fraudulent particularly if associated with a nonjudicial foreclosure - please feel free to send them to me with a short explanation. Finally, please bear in mind that current Washington law does not require the recording of an assignment of deed of trust each time the associated promissory note or other negotiable instrument is negotiated or assigned.

\section{Regards,}

Audrey L. Udashen

Assistant Attorney General | Consumer Protection Division

Washington State Attorney General's Office

800 Fifth Avenue, Suite 2000

Seattle, WA 98104

(206) 254-0561

audreyu@atg.wa.gov 


\section{APPENDIX K 10.26.2015 Letter to Washington Attorney General}

James Campbell

Pctober 26, 2015

9209 NE $173^{\text {rd }}$ P1.

Bothell, WA 98011

Ms. Audrey L. Udashen

Assistant Attorney General | Consumer Protection Division

Washington State Attorney General's Office

800 Fifth Avenue, Suite 2000

Seattle, WA 98104

RE: Fraudulent Non-judicial Foreclosures

Dear Ms. Udashen:

Thank you for your prompt response to my correspondence of September 24 , in which you invited me to furnish information on specific DOT assignments that $I$ believe to be fraudulent. Appendix $F$ features a list of 21 such assignments. This list was compiled starting with a random sample of 151 Notice of Trustee's Sales that were recorded in Snohomish County in 2012. They share a common feature: they were all preceded by an assignment to a closed REMIC which could not possibly become a lawful beneficiary. Thus the assignments are legal nullities, meaning that the foreclosure activities which ensued were invalid. By way of a single example, I will demonstrate to you how and why this is so.

The 21 homeowners featured in Appendix F were each served with a Notice of Trustee's Sale, eight of which did follow through to a non-judicial foreclosure. The Burgette property is one of those eight. The following sequence of events is common to all eight:

A. A Deed of Trust is executed and recorded, which names a "Borrower", a "Beneficiary" and a "Trustee". In the case of Burgette, those parties are Burgette, National City Mortgage and Chicago Title respectively.

B. An Assignment of Deed of Trust is executed which names the assignor (existing beneficiary) and the assignee (successor beneficiary). In the case of Burgette, those parties are PNC Bank (as successor to National City Mortgage) and Deutsche Bank National Trust Company Americas As Trustee RALJ 2004-QA6 respectively.

C. An Appointment of Successor Trustee is executed and recorded, which names the successor beneficiary and the successor trustee. In the case of Burgette, those parties are Deutsche Bank National Trust Company Americas As Trustee RALI 2004-QA6 (as successor to PNC Bank) and Northwest Trustee Services (as successor trustee to Chicago Title) respectively.

D. A Notice of Trustee's Sale is executed naming a Grantor and Grantee. In the case of Burgette, those parties are Burgette and Northwest Trustee Services respectively.

E. A Trustee's Deed is executed and recorded, which names a different Grantor and Grantee. In the case of Burgette, those parties are Northwest Trustee Services and Deutsche Bank National 
Trust Company Americas As Trustee RALI 2004-QA6 (which became the successor to Burgette as owner in title) respectively.

This sequence became unlawful at Step B because it was impossible for Burgette's loan to become a component of RALI 2004-QA6 in 2012. The following properly states the required timeliness for any mortgage to be assigned to RALI 2004-QA6 (see: Appendix G) ${ }^{1}$.

The Mortgage Loans have an aggregate principal balance as of the Cut-off Date (December 4, 2004) of $\$ 720,298,725.34$.

Within thirty Business Days following the receipt of the original of all of the documents or instruments set forth in Section 2.01(b)(I)(iii), The Company shall promptly cause to be recorded in the appropriate public office for real property records the Assignment referred to in clause (I) (iii) of Section 2.01(b). In connection with such assignment, the Company does hereby deliver to, and deposit with, the Trustee the original recorded assignment or assignments of the Mortgage showing an unbroken chain of title from the originator thereof to the Person assigning it to the Trustee with evidence of recording indicated thereon ${ }^{2}$

The Trustee or Custodian (such Custodian being so obligated under a Custodial Agreement) agrees, for the benefit of Certificateholders, to review each Mortgage File delivered to it pursuant to Section 2.01(b) within 45 days after the Closing Date (December 29, 2004) to ascertain that all required documents (specifically as set forth in Section 2.01(b)), have been executed and received...

There is no "wiggle room" in the foregoing to allow the Burgette loan to be assigned to RALI 2004QA6 more than seven years after the Cut-off Date; nor is there any ambiguity as to the date after which the Trustee or Custodian may not receive a mortgage on behalf of this REMIC (within 45 days after the Closing Date of December 29, 2004).

The Burgette assignment was executed on January 9, 2012 by an "Authorized Signer" for PNC Bank: Glenn S. Byrd. Most probably, Ms. Byrd was simply instructed by a superior to sign this document. The assignment was then given over to Kathy Taggart, an employee of Northwest Trustee Services, who was instructed by her superior to record it. Then a recording officer, with no questions asked, made it a matter of public record in exchange for $\$ 14$.

Who authorized Ms. Byrd to sign this assignment and does that person have any expertise in interpreting the REMIC requirements? And what about Ms. Taggert and her superiors. Certain people near the apex of both these organizations know that this assignment is bogus because it fails to comply with the timing rules set forth in RALI 2004-QA6.

In addition to a wrongful slandering of Burgette's title with a bogus assignment, other disturbing questions come to the fore. If Burgette's loan was not a component of RALI 2004-QA6 in

'The complete text of RALI $2004-Q .16$ can be located in the SEC online archives: http//www.sec.gov/Archives/edgar/data 1313040000131304005000002 0001313040-05-000002.txt

'For clarification purposes, this paragraph is a compilation of the RALI 2004-QA6 terms set forth in Appendix G.

Page 2 of 3 
2004 , how was that $\$ 720,298,725.34$ worth of loans calculated? How many other loans were "assigned" to this closed REMIC in the past 10 years. Did the creators of RALI 2004-QA6 sell certificates to the public back in 2004 with the false representation that these shares were collateralized by real estate loans?

What happened to Burgette, and so many other homeowners (not to mention the certificate holders of unsecured REMICs), appears to be outright fraud on a massive scale. I have yet to see a compelling argument to the contrary. I don't know what remedy in law can be applied to the correct wrongs that were committed in the past. But if recording these types of assignments are allowed to continue into the indefinite future, then we might as well not have a rule of law.

The county recording office is the place where these fraudulent non-judicial foreclosures can be stopped, which is why I originally asked Ms. Carolyn Weikel (the Snohomish County Auditor) to stop recording these assignments to closed trusts. But according to both Ms. Weikel and the Deputy Prosecutor, the auditor is obligated to record documents even if they are willful violations of RCW 40.16.030. That may be so; I don't know. But there has got to be a way to put a stop to this. Thank you for your time.

Respectfully,

\author{
James Campbell \\ Candidate | Master of Arts in Policy Studies (MAPS) \\ University of Washington Bothell \\ 206-427-5653 \\ jc68@uw.edu
}




\section{APPENDIX L 11.09.2015 Online Message from Washington Attorney General}

\section{Fraudulent Non-judicial foreclosures}

7 messages

Udashen, Audrey (ATG) <AudreyU@atg.wa.gov>

To: "jc68@uw.edu" <jc68@uw.edu>

Cc: ATG MI CPR Contact AGO <CPRcontact@atg.wa.gov>

Mr. Campbell,

Thank you for your letter dated October 26, 2015 regarding assignments of Deeds of Trust. My office takes unfair and deceptive practices in the foreclosure process very seriously and appreciates you bringing these issues to our attention. My office also encourages you to bear in mind that assignments of deeds of trust are not required to be recorded in Washington.

My office is prohibited from giving legal advice. Therefore, if you need assistance in the matters detailed in your letter, we suggest that you contact a housing counselor or attorney. If you need referrals to these services you can contact the following organizations:

Washington Homeownership Resource Center- (877) 894-4663

Northwest Justice Project's CLEAR line- 1-888-201-1014.

Regards,

Audrey L. Udashen

Assistant Attorney General | Consumer Protection Division

Washington State Attorney General's Office

800 Fifth Avenue, Suite 2000

Seattle, WA 98104

(206) 254-0561

audreyu@atg.wa.gov 
James Campbell | Master of Arts in Policy Studies

University of Washington Bothell | June 6, 2016

An Inquiry into the Legal Standing of Rogue REMICs in Foreclosures

\section{APPENDIX M 04.12.2016 Online Message to Washington Attorney General}

James Campbell <jc68@uw.edu>

드 Apr 12

$h$

Ms. Udashen:

I was disappointed by the comments you made to me on November 9 . At first, I found them to be dismissive and condescending. But upon reflection, I concluded that we simply had a misunderstanding -- one that I will now attempt to clear up.

First, I was not requesting legal advice. You asked me to furnish a specific example of a fraudulent non-judicial foreclosure along with a brief explanation as why it is fraudulent. I furnished one, the Burgette foreclosure, along with an explanation. I followed up with a few rhetorical questions. Those rhetorical questions were not requests for legal advice. My intent was to place this one foreclosure in the context of a much larger problem that is criminal in nature.

Second, I agree with your statements that all DOT assignments need not be recorded. I never argued otherwise nor did I even raise the issue. Unrecorded assignments is a non-issue. The issue at hand is the recording of void assignments. If a foreclosure is accomplished with reliance on a void assignment, then the entire foreclosure process is unlawful. In the case of Burgette, the January 9, 2012 assignment from PNC Bank to "Deutsche Bank Trust Company Americas As Trustee of RALI 2004-QA6" is a void assignment. The recording of a void assignment is a violation of both RCW 43.16 .030 RCW and 9.38.030. That means the Trustee's Deed that was recorded on May 7, 2012 is void as well. This is but one of 21 such assignments I have in my possession.

I have explained to you in detail how certain REMICs are continuously committing criminal acts in the hope that you would launch a criminal investigation of serial recorders of void assignments. I am nearing the end of the research phase of my capstone project and I am now preparing a presentation to the UWB faculty which encapsulates this Policy Problem. Non-enforcement of existing State law is at the heart of the problem.

Although the essay and presentation are still both in draft form, I have decided to share them with you now because putting a stop to the recording of void assignments is of the utmost urgency. Appendices B through L include all written communications that I have had with you, the Snohomish County Audito and the Snohomish County Prosecuting Attorney.

At this time, I would like to give you an opportunity to reformulate or supplement your response to me of November 9,2015 . Thank you

James Campbell

James Campbell| Candidate

2016 Master of Arts in Policy Studies

University of Washington Bothell.

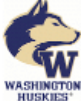


James Campbell | Master of Arts in Policy Studies

University of Washington Bothell | June 6, 2016

An Inquiry into the Legal Standing of Rogue REMICs in Foreclosures

\section{APPENDIX N 04.26.2016 Online Message From Washington Attorney General}

to me, ATG V

Mr. Campbell,

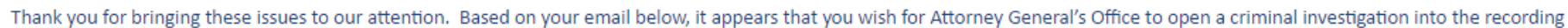

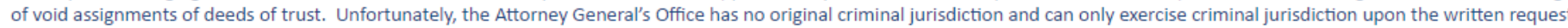
of an elected county prosecutor, the governor, or a majority of the committee charged with the oversight of the organized crime intelligence unit. As such, we do not have the

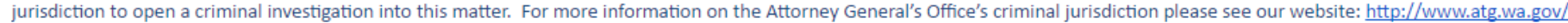
$\underline{\text { frequently-asked-questions-fags }}$

Although the Attorney General's Office does not have original criminal jurisdiction, we do conduct investigations and take enforcement action against violations of the Consumer Protection Act, a civil statute. We have taken enforcement action against violations of the Consumer Protection Act by entities involved in the mortgage industry on a number of occasions. We set our priorities for our investigations, which are conducted on a confidential basis, on a number of factors, one of which is information and input from constituents. Therefore, we thank you for the information you have provided.

Regards,

Audrey L. Udashen

Assistant Attomey General | Consumer Protection Dirvision

Washington State Attomer General's Office

800 Fifth Avenue, Suite 2000

Seattle, WA 98104

(206) 254-0561

audremı@ato.wa.gov 


\section{APPENDIX O 04.26.2016 Online Message to Washington Attorney General}

From: James Campbell [mailto:jc68@uw.edu]

Sent: Tuesday, April 12, 2016 7:38 AM

To: Udashen, Audrey (ATG)

Subject: Re: Fraudulent Non-judicial foreclosures

Ms. Udashen:

James Campbell <jc68@uw.edu>

Ms. Udashen,

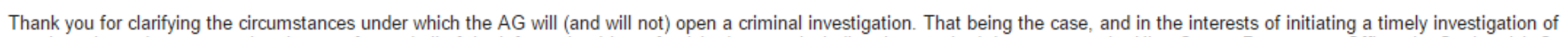

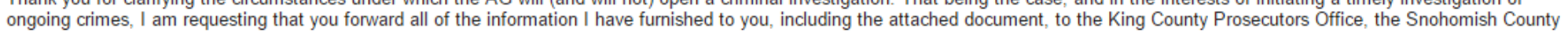
Prosecutor's Office, the governor's office and the organized crime intelligence unit. RCW 43.43.854.

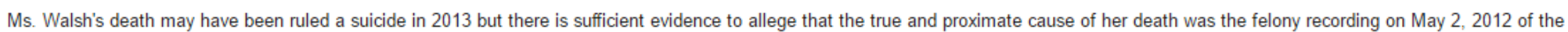
DOT assignment recorded in King County instrument No. 20120503001576. RCW 40.16.030.

Please confirm to me that you have forwarded this information to these four entities at your earliest convenience. Thank you.

James Campbell

James Campbell | Candidate

2016 Master of Arts in Policy Studies

University of Washington Bothell

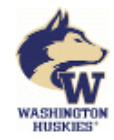

\section{APPENDIX P 05.21.2016 Message to AG and Prosecutors of King and Snohomish Counties}

Ms. Udashen:

It was ruled a suicide but Phyllis Walsh was murdered.

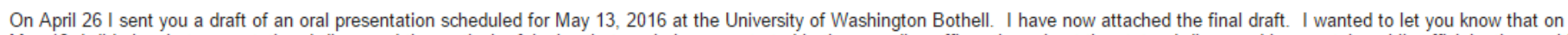

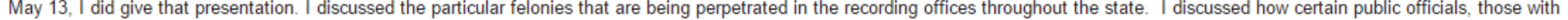
the ability and responsibility to stop these crimes, are continuously allowing them to occur right under their noses.

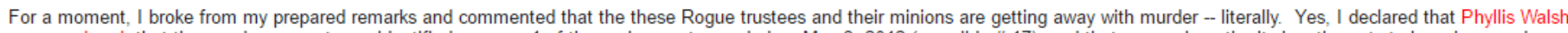

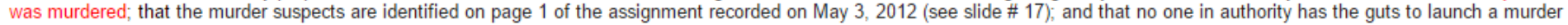

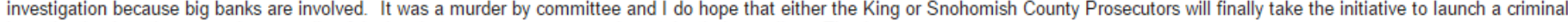
investigation into these ongoing recording felonies that cause so many people to take their own lives. Thank you.

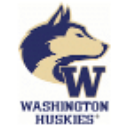


James Campbell | Master of Arts in Policy Studies

University of Washington Bothell | June 6, 2016

An Inquiry into the Legal Standing of Rogue REMICs in Foreclosures

\section{APPENDIX Q 05.23.2016 Online Message from Snohomish Prosecuting Attorney}

5252016

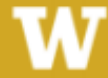

UW Mail - Complaint

James Campbell <jc68@uw.edu>

\section{Complaint}

1 message

Lenz, Bob <rlenz@co.snohomish.wa.us>

To: "jc68@uw.edu" <jc68@uw.edu>

Mon, May 23, 2016 at 4:32 PM

Mr. James Campbell:

I've reviewed the information you have sent to our office. The Snohomish County Prosecuting Attorney's Office doesn't initiate or conduct criminal investigations. It also appears this specific event occurred in King County. Our office will not take any action on this information you provided. The appropriate venue would be for you to contact the local law enforcement agency where you allege this crime took place.

Sincerely,

Robert Lenz

Chief of Operations

Snohomish County Prosecuting Attorney

Robert J. Drewel Bldg. / 7th Floor

3000 Rockefeller Ave

Everett, WA 98201

425-388-3514 (phone) - 425-388-7172 (fax)

rlenz@snoco.org 


\title{
APPENDIX X IRS CODE 26 U.S.C. §§ 860A-860G (REMICs)
}

\author{
26 U.S. Code $\S 860 \mathrm{~F}$ - Other rules
}

Current through Pub. L. 114-38. (See Public Laws for the current Congress.)

\section{(a) 100 PERCENT TAX ON PROHIBITED TRANSACTIONS}

(1) TAX IMPOSED

There is hereby imposed for each taxable year of a REMIC a tax equal to 100 percent of the net income derived from prohibited transactions.

(2) Prohibited transaction For purposes of this part, the term "prohibited transaction" means-

(A) Disposition of qualified mortgage The disposition of any qualified mortgage transferred to the REMIC other than a disposition pursuant to-

(i)

the substitution of a qualified replacement mortgage for a qualified mortgage (or the repurchase in lieu of substitution of a defective obligation),

(ii)

a disposition incident to the foreclosure, default, or imminent default of the mortgage,

(iii)

the bankruptcy or insolvency of the REMIC, or

(iv)

a qualified liquidation.

(B) Income from nonpermitted assets

The receipt of any income attributable to any asset which is neither a qualified mortgage nor a permitted investment.

\section{(C) Compensation for services}

The receipt by the REMIC of any amount representing a fee or other compensation for services.

\section{(D) Gain from disposition of cash flow investments}

Gain from the disposition of any cash flow investment other than pursuant to any qualified liquidation.

\section{(3) DETERMINATION OF NET INCOME}

For purposes of paragraph (1), the term "net income derived from prohibited transactions" means the excess of the gross income from prohibited transactions over the deductions allowed by this chapter which are directly connected with such transactions; except that there shall not be taken into account any item attributable to any prohibited transaction for which there was a loss.

(4) QUALIFIED LIQUIDATION For purposes of this part-

(A) In general The term "qualified liquidation" means a transaction in which-

(i)

the REMIC adopts a plan of complete liquidation,

(ii)

such REMIC sells all its assets (other than cash) within the liquidation period, and 


\section{James Campbell | Master of Arts in Policy Studies \\ University of Washington Bothell | June 6, 2016 \\ An Inquiry into the Legal Standing of Rogue REMICs in Foreclosures}

(iii)

all proceeds of the liquidation (plus the cash), less assets retained to meet claims, are credited or distributed to holders of regular or residual interests on or before the last day of the liquidation period.

(B) Liquidation period The term "liquidation period" means the period-

(i)

beginning on the date of the adoption of the plan of liquidation, and

(ii)

ending at the close of the 90th day after such date.

(5) EXCEPTIONS Notwithstanding subparagraphs (A) and (D) of paragraph (2), the term "prohibited transaction" shall not include any disposition-

(A)

required to prevent default on a regular interest where the threatened default resulted from a default on 1 or more qualified mortgages, or

(B)

to facilitate a clean-up call (as defined in regulations).

(b) Treatment OF Transfers to THE REMIC

(1) TreatMENT OF TRANSFEROR

(A) Nonrecognition gain or loss

No gain or loss shall be recognized to the transferor on the transfer of any property to a REMIC in exchange for regular or residual interests in such REMIC.

\section{(B)Adjusted bases of interests}

The adjusted bases of the regular and residual interests received in a transfer described in subparagraph (A) shall be equal to the aggregate adjusted bases of the property transferred in such transfer. Such amount shall be allocated among such interests in proportion to their respective fair market values.

(C)Treatment of nonrecognized gain If the issue price of any regular or residual interest exceeds its adjusted basis as determined under subparagraph (B), for periods during which such interest is held by the transferor (or by any other person whose basis is determined in whole or in part by reference to the basis of such interest in the hand of the transferor) -

(i)

in the case of a regular interest, such excess shall be included in gross income (as determined under rules similar to rules of section 1276(b)), and

(ii)

in the case of a residual interest, such excess shall be included in gross income ratably over the anticipated period during which the REMIC will be in existence.

(D)Treatment of nonrecognized lossIf the adjusted basis of any regular or residual interest received in a transfer described in subparagraph (A) exceeds its issue price, for periods during which such interest is held by the transferor (or by any other person whose basis is determined in whole or in part by reference to the basis of such interest in the hand of the transferor) (i)

in the case of a regular interest, such excess shall be allowable as a deduction under rules similar to the rules of section 171 , and

(ii)

Page 95 of 103 
in the case of a residual interest, such excess shall be allowable as a deduction ratably over the anticipated period during which the REMIC will be in existence.

\section{(2)BASIS TO REMIC}

The basis of any property received by a REMIC in a transfer described in paragraph (1)(A) shall be its fair market value immediately after such transfer.

(c)DISTRIBUTIONS OF PROPERTY If a REMIC makes a distribution of property with respect to any regular or residual interest-

(1)

notwithstanding any other provision of this subtitle, gain shall be recognized to such REMIC on the distribution in the same manner as if it had sold such property to the distributee at its fair market value, and

(2)

the basis of the distributee in such property shall be its fair market value.

(d) COORDination WiTH WASH SALE RULES For purposes of section 1091-

(1)

any residual interest in a REMIC shall be treated as a security, and

(2)in applying such section to any loss claimed to have been sustained on the sale or other disposition of a residual interest in a REMIC-

(A)

except as provided in regulations, any residual interest in any REMIC and any interest in a taxable mortgage pool (as defined in section 7701(i)) comparable to a residual interest in a REMIC shall be treated as substantially identical stock or securities, and

(B)

subsections (a) and (e) of such section shall be applied by substituting "6 months" for "30 days" each place it appears.

\section{(e) Treatment Under SUbTitLe $F$}

For purposes of subtitle F, a REMIC shall be treated as a partnership (and holders of residual interests in such REMIC shall be treated as partners). Any return required by reason of the preceding sentence shall include the amount of the daily accruals determined under section $860 \mathrm{E}(\mathrm{c})$. Such return shall be filed by the REMIC. The determination of who may sign such return shall be made without regard to the first sentence of this subsection.

26 U.S. Code $\S 860 \mathrm{G}$ - Other definitions and special rules

(a) DEFINITIONS For purposes of this part-

prev $\mid \underline{\text { next }}$

(1) REGULAR INTEREST The term "regular interest" means any interest in a REMIC which is issued on the startup day with fixed terms and which is designated as a regular interest if -

(A)

such interest unconditionally entitles the holder to receive a specified principal amount (or other similar amount), and

(B)interest payments (or other similar amount), if any, with respect to such interest at or before maturity-

(i)

are payable based on a fixed rate (or to the extent provided in regulations, at a variable rate), or

(ii)

consist of a specified portion of the interest payments on qualified mortgages and such portion does not vary during the period such interest is outstanding. 
The interest shall not fail to meet the requirements of subparagraph (A) merely because the timing (but not the amount) of the principal payments (or other similar amounts) may be contingent on the extent of prepayments on qualified mortgages and the amount of income from permitted investments. An interest shall not fail to qualify as a regular interest solely because the specified principal amount of the regular interest (or the amount of interest accrued on the regular interest) can be reduced as a result of the nonoccurrence of 1 or more contingent payments with respect to any reverse mortgage loan held by the REMIC if, on the startup day for the REMIC, the sponsor reasonably believes that all principal and interest due under the regular interest will be paid at or prior to the liquidation of the REMIC.

\section{(2) RESIDUAL INTEREST}

The term "residual interest" means an interest in a REMIC which is issued on the startup day, which is not a regular interest, and which is designated as a residual interest.

(3) QUALIFIED MORTGAGE The term "qualified mortgage" means-

(A) any obligation (including any participation or certificate of beneficial ownership therein) which is principally secured by an interest in real property and which-

(i)

is transferred to the REMIC on the startup day in exchange for regular or residual interests in the REMIC,

(ii)

is purchased by the REMIC within the 3-month period beginning on the startup day if, except as provided in regulations, such purchase is pursuant to a fixed-price contract in effect on the startup day, or

(iii) represents an increase in the principal amount under the original terms of an obligation described in clause (i) or (ii) if such increase-

(I)

is attributable to an advance made to the obligor pursuant to the original terms of a reverse mortgage loan or other obligation,

(II)

occurs after the startup day, and

(III)

is purchased by the REMIC pursuant to a fixed price contract in effect on the startup day. 11

(B)

any qualified replacement mortgage, and

(C)

any regular interest in another REMIC transferred to the REMIC on the startup day in exchange for regular or residual interests in the REMIC.

For purposes of subparagraph (A), any obligation secured by stock held by a person as a tenant-stockholder (as defined in section 216) in a cooperative housing corporation (as so defined) shall be treated as secured by an interest in real property. For purposes of subparagraph (A), any obligation originated by the United States or any State (or any political subdivision, agency, or instrumentality of the United States or any State) shall be treated as principally secured by an interest in real property if more than 50 percent of such obligations which are transferred to, or purchased by, the REMIC are principally secured by an interest in real property (determined without regard to this sentence).

(4) QUALIFIED REPLACEMENT MORTGAGE The term "qualified replacement mortgage" means any obligation-

(A)

which would be a qualified mortgage if transferred on the startup day in exchange for regular or residual interests in the REMIC, and 
(B) which is received for-

(i)

another obligation within the 3-month period beginning on the startup day, or

(ii)

a defective obligation within the 2-year period beginning on the startup day.

(5)Permitted investments The term "permitted investments" means any-

(A)

cash flow investment,

(B)

qualified reserve asset, or

(C)

foreclosure property.

(6) CASH FLOW INVESTMENT

The term "cash flow investment" means any investment of amounts received under qualified mortgages for a temporary period before distribution to holders of interests in the REMIC.

\section{(7)QUALIFIED RESERVE ASSET}

\section{(A)In general}

The term "qualified reserve asset" means any intangible property which is held for investment and as part of a qualified reserve fund.

(B)Qualified reserve fundFor purposes of subparagraph (A), the term "qualified reserve fund" means any reasonably required reserve to-

(i)

provide for full payment of expenses of the REMIC or amounts due on regular interests in the event of defaults on qualified mortgages or lower than expected returns on cash flow investments, or

(ii)

provide a source of funds for the purchase of obligations described in clause (ii) or (iii) of paragraph (3)(A).

The aggregate fair market value of the assets held in any such reserve shall not exceed 50 percent of the aggregate fair market value of all of the assets of the REMIC on the startup day, and the amount of any such reserve shall be promptly and appropriately reduced to the extent the amount held in such reserve is no longer reasonably required for purposes specified in clause (i) or (ii) of this subparagraph.

\section{(C)Special rule}

A reserve shall not be treated as a qualified reserve for any taxable year (and all subsequent taxable years) if more than 30 percent of the gross income from the assets in such fund for the taxable year is derived from the sale or other disposition of property held for less than 3 months. For purposes of the preceding sentence, gain on the disposition of a qualified reserve asset shall not be taken into account if the disposition giving rise to such gain is required to prevent default on a regular interest where the threatened default resulted from a default on 1 or more qualified mortgages.

(8)FORECLOSURE PROPERTY The term "foreclosure property" means property-

(A)

which would be foreclosure property under section 856(e) (without regard to paragraph (5) thereof) if acquired by a real estate investment trust, and 


\section{(B)}

which is acquired in connection with the default or imminent default of a qualified mortgage held by the REMIC. Solely for purposes of section $860 \mathrm{D}$ (a), the determination of whether any property is foreclosure property shall be made without regard to section 856(e)(4).

\section{(9) STARTUP DAY}

The term "startup day" means the day on which the REMIC issues all of its regular and residual interests. To the extent provided in regulations, all interests issued (and all transfers to the REMIC) during any period (not exceeding 10 days) permitted in such regulations shall be treated as occurring on the day during such period selected by the REMIC for purposes of this paragraph.

\section{(10) ISSUE PRICE}

The issue price of any regular or residual interest in a REMIC shall be determined under section 1273(b) in the same manner as if such interest were a debt instrument; except that if the interest is issued for property, paragraph (3) of section 1273(b) shall apply whether or not the requirements of such paragraph are met.

(b) TREATMENT OF NONRESIDENT ALIENS AND FOREIGN CORPORATIONSIf the holder of a residual interest in a REMIC is a nonresident alien individual or a foreign corporation, for purposes of sections 871(a), 881, 1441, and 1442-

(1)

amounts includible in the gross income of such holder under this part shall be taken into account when paid or distributed (or when the interest is disposed of), and

(2)

no exemption from the taxes imposed by such sections (and no reduction in the rates of such taxes) shall apply to any excess inclusion.

The Secretary may by regulations provide that such amounts shall be taken into account earlier than as provided in paragraph (1) where necessary or appropriate to prevent the avoidance of tax imposed by this chapter.

(c)TAX ON INCOME FROM FORECLOSURE PROPERTY

(1)IN GENERAL

A tax is hereby imposed for each taxable year on the net income from foreclosure property of each REMIC. Such tax shall be computed by multiplying the net income from foreclosure property by the highest rate of tax specified in section 11(b).

\section{(2)NET INCOME FROM FORECLOSURE PROPERTY}

For purposes of this part, the term "net income from foreclosure property" means the amount which would be the REMIC's net income from foreclosure property under section 857(b)(4)(B) if the REMIC were a real estate investment trust.

\section{(d)TAX ON CONTRIBUTIONS AFTER STARTUP DATE}

\section{(1)IN GENERAL}

Except as provided in paragraph (2), if any amount is contributed to a REMIC after the startup day, there is hereby imposed a tax for the taxable year of the REMIC in which the contribution is received equal to 100 percent of the amount of such contribution.

(2)EXCEPTIONS Paragraph (1) shall not apply to any contribution which is made in cash and is described in any of the following subparagraphs:

(A)

Any contribution to facilitate a clean-up call (as defined in regulations) or a qualified liquidation. 


\section{James Campbell | Master of Arts in Policy Studies \\ University of Washington Bothell | June 6, 2016 \\ An Inquiry into the Legal Standing of Rogue REMICs in Foreclosures}

(B)

Any payment in the nature of a guarantee.

(C)

Any contribution during the 3-month period beginning on the startup day.

(D)

Any contribution to a qualified reserve fund by any holder of a residual interest in the REMIC.

(E)

Any other contribution permitted in regulations.

(e)REGULATIONS The Secretary shall prescribe such regulations as may be necessary or appropriate to carry out the purposes of this part, including regulations-

(1)

to prevent unreasonable accumulations of assets in a REMIC,

(2)

permitting determinations of the fair market value of property transferred to a REMIC and issue price of interests in a REMIC to be made earlier than otherwise provided,

(3)

requiring reporting to holders of residual interests of such information as frequently as is necessary or appropriate to permit such holders to compute their taxable income accurately,

(4)

providing appropriate rules for treatment of transfers of qualified replacement mortgages to the REMIC where the transferor holds any interest in the REMIC, and

(5)

providing that a mortgage will be treated as a qualified replacement mortgage only if it is part of a bona fide replacement (and not part of a swap of mortgages).

(Added Pub. L. 99-514, title VI, § 671(a), Oct. 22, 1986, 100 Stat. 2315; amended Pub. L. 100-647, title I, § 1006(t)(5)(A)(E), (6)-(8)(B), (9)(A), (10), Nov. 10, 1988, 102 Stat. 3420-3422; Pub. L. 101-239, title VII, § 7811(c)(9), Dec. 19, 1989, 103 Stat. 2408; Pub. L. 101-508, title XI, §11704(a)(9), Nov. 5, 1990, 104 Stat. 1388-518; Pub. L. 104-188, title I, §1621(b)(6), Aug. 20, 1996, 110 Stat. 1867; Pub. L. 108-357, title VIII, § 835(b)(5)-(8), Oct. 22, 2004, 118 Stat. 1593; Pub. L. 109-135, title IV, § 403(cc), Dec. 21, 2005, 119 Stat. 2630.) 


\section{APPENDIX Y Applicable Washington State Statutes}

\section{RCW 9A.04.030 State criminal jurisdiction.}

The following persons are liable to punishment:

(1) A person who commits in the state any crime, in whole or in part.

\section{RCW 9A.08.010 General requirements of culpability.}

(1) Kinds of Culpability Defined.

(b) KNOWLEDGE. A person knows or acts knowingly or with knowledge when:

(i) he or she is aware of a fact, facts, or circumstances or result described by a statute defining an offense; or

(ii) he or she has information which would lead a reasonable person in the same situation to believe that facts exist which facts are described by a statute defining an offense.

\section{RCW 9A.72.080 Statement of what one does not know to be true.}

Every unqualified statement of that which one does not know to be true is equivalent to a statement of that which he or she knows to be false.

\section{RCW 9A.80.010 Official misconduct.}

(1) A public servant is guilty of official misconduct if, with intent to obtain a benefit or to deprive another person of a lawful right or privilege:

(a) He or she intentionally commits an unauthorized act under color of law; or

(b) He or she intentionally refrains from performing a duty imposed upon him or her by law.

(2) Official misconduct is a gross misdemeanor. 


\section{RCW 9.38.020 False representation concerning title.}

Every person who shall maliciously or fraudulently execute or file for record any instrument, or put forward any claim, by which the right or title of another to any real or personal property is, or purports to be transferred, encumbered or clouded, shall be guilty of a gross misdemeanor.

\section{RCW 40.16.030 Offering false instrument for filing or record}

Every person who shall knowingly procure or offer any false or forged instrument to be filed, registered, or recorded in any public office, which instrument, if genuine, might be filed, registered or recorded in such office under any law of this state or of the United States, is guilty of a class $\mathrm{C}$ felony and shall be punished by imprisonment in a state correctional facility for not more than five years, or by a fine of not more than five thousand dollars, or by both.

\section{RCW 42.20.100 Failure of duty by public officer a misdemeanor.}

Whenever any duty is enjoined by law upon any public officer or other person holding any public trust or employment, their wilful neglect to perform such duty, except where otherwise specially provided for, shall be a misdemeanor.

\section{RCW 61.24.010 Trustee, qualifications—-Successor trustee.}

(4) The trustee or successor trustee has a duty of good faith to the borrower, beneficiary, and grantor

\section{RCW 61.24.030 Requisites to trustee's sale.}

\section{It shall be requisite to a trustee's sale:}

(7)(a) That, for residential real property, before the notice of trustee's sale is recorded, transmitted, or served, the trustee shall have proof that the beneficiary is the owner of any promissory note or other obligation secured by the deed of trust. A declaration by the beneficiary made under the penalty of perjury stating that the beneficiary is the actual holder of the promissory note or other obligation secured by the deed of trust shall be sufficient proof as required under this subsection, 


\section{RCW 65.08.150 Duty to record.}

A recording officer, upon payment or tender to him or her of the lawful fees therefor, shall record in his or her office any instrument authorized or permitted to be so recorded by the laws of this state or by the laws of the United States.

\section{Appendix Z New York State Trust Law}

N.Y. ESTATES, POWERS \& TRUSTS LAW § 7-2.4. "If the trust is expressed in the instrument creating the estate of the trustee, every sale, conveyance or other act of the trustee in contravention of the trust, except as authorized by this article and by any other provision of law, is void." 